\title{
Het technisch beroepsonderwijs in het Technogebied Zuid-Oost-Nederland: Spreiding, deelname en de aansluiting met de regionale arbeidsmarkt
}

Citation for published version (APA):

Cörvers, F., Coenen, J. B., Heijke, J. A. M., \& Montizaan, R. M. (2005). Het technisch beroepsonderwijs in het Technogebied Zuid-Oost-Nederland: Spreiding, deelname en de aansluiting met de regionale arbeidsmarkt. ROA. ROA Reports No. 7 https://doi.org/10.26481/umarep.2005007

Document status and date:

Published: 01/01/2005

DOI:

10.26481/umarep.2005007

Document Version:

Publisher's PDF, also known as Version of record

Please check the document version of this publication:

- A submitted manuscript is the version of the article upon submission and before peer-review. There can be important differences between the submitted version and the official published version of record.

People interested in the research are advised to contact the author for the final version of the publication, or visit the DOI to the publisher's website.

- The final author version and the galley proof are versions of the publication after peer review.

- The final published version features the final layout of the paper including the volume, issue and page numbers.

Link to publication

\footnotetext{
General rights rights.

- You may freely distribute the URL identifying the publication in the public portal. please follow below link for the End User Agreement:

www.umlib.nl/taverne-license

Take down policy

If you believe that this document breaches copyright please contact us at:

repository@maastrichtuniversity.nl

providing details and we will investigate your claim.
}

Copyright and moral rights for the publications made accessible in the public portal are retained by the authors and/or other copyright owners and it is a condition of accessing publications that users recognise and abide by the legal requirements associated with these

- Users may download and print one copy of any publication from the public portal for the purpose of private study or research.

- You may not further distribute the material or use it for any profit-making activity or commercial gain

If the publication is distributed under the terms of Article 25fa of the Dutch Copyright Act, indicated by the "Taverne" license above, 


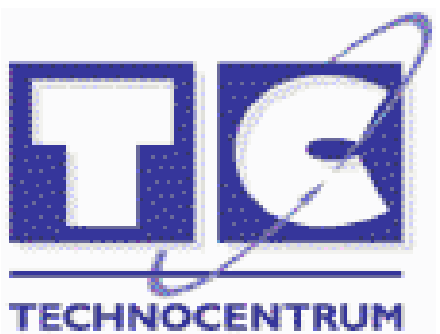

\section{Het technisch beroepsonderwijs in het Technogebied Zuidoost-Nederland}

Spreiding, deelname en de aansluiting met de regionale arbeidsmarkt

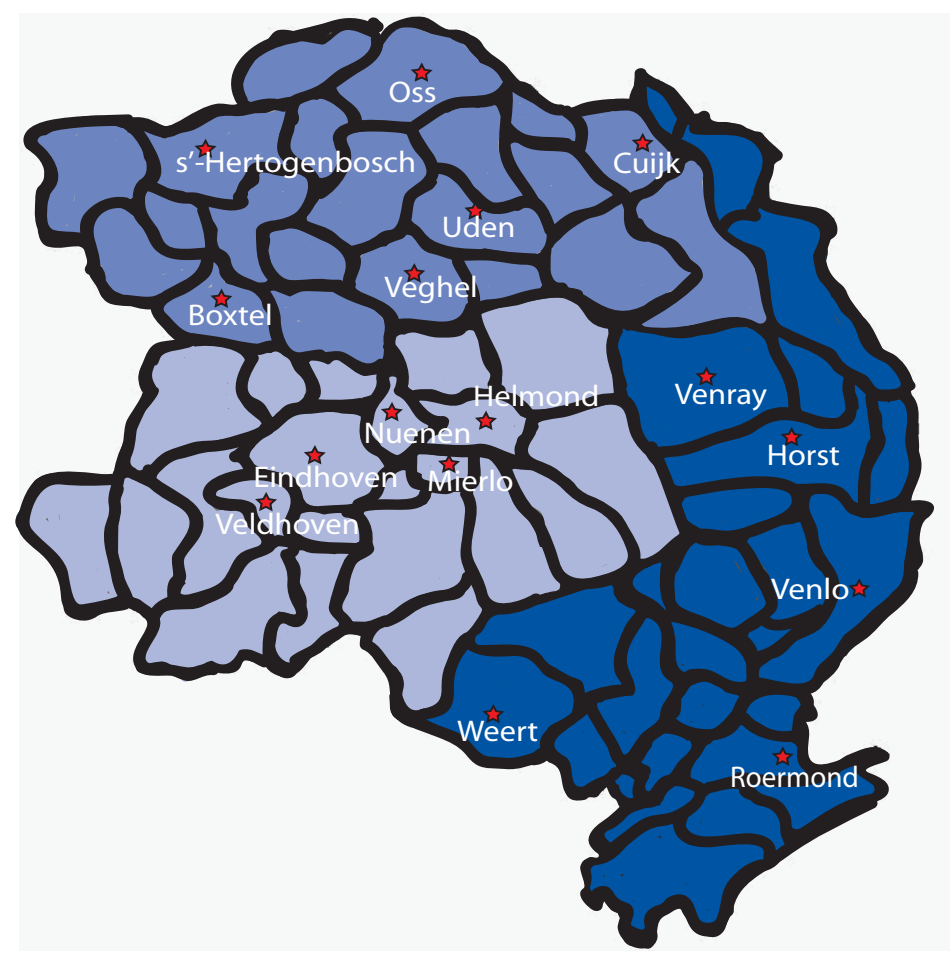

Onderzoek in opdracht van Technocentrum Zuidoost-Nederland uitgevoerd door

Researchcentrum voor Onderwijs en Arbeidsmarkt

Faculteit der Economische Wetenschappen en Bedrijfskunde

Universiteit Maastricht

juli 2005 



\title{
Het technisch beroepsonderwijs
}

in het Technogebied Zuidoost-Nederland:

Spreiding, deelname en de aansluiting met de regionale arbeidsmarkt

ROA-R-2005/7

\author{
F. Cörvers \\ J. Coenen \\ H. Heijke \\ R. Montizaan
}

Researchcentrum voor Onderwijs en Arbeidsmarkt

Faculteit der Economische Wetenschappen en Bedrijfskunde Universiteit Maastricht

Maastricht, juli 2005 
Opdrachtgever:

Technocentrum Zuidoost-Nederland

Postbus 6101

5600 HC Eindhoven

Informatie bij:

Toon Berkers, tel.nr.: 0475-349342, of

Stef Strous, tel.nr.: 040-2694013.

ISBN-90-5321-424-0

Sec05.080.doc 


\section{Inhoud}

Bladzijde

Voorwoord

1 Inleiding

2 Regionale kaart van het middelbaar technisch beroepsonderwijs 5

2.1 Spreiding van opleidingslocaties in het MBO 6

2.2 Deelname aan MBO techniek in Nederland 11

2.3 Deelname aan MBO techniek in het Technogebied 14

2.4 Deelname aan techniekonderwijs in Maaseik 18

2.5 Leerlingen per deelsector techniek in het Technogebied 19

$\begin{array}{ll}2.6 \text { Conclusies } & 21\end{array}$

3 Doorstroom binnen de beroepskolom en arbeidsmarktintrede 25

3.1 Uitstroom van VMBO 26

$\begin{array}{lll}3.2 & \text { Arbeidsmarktintrede na MBO } 30\end{array}$

3.3 Doorstroom binnen de beroepskolom na MBO 33

3.4 Arbeidsmarktintrede na $\mathrm{HBO} \quad 38$

3.5 Conclusies $\quad 40$

4 Arbeidsmarkt naar beroep en opleiding voor techniek 43

4.1 Werkgelegenheidsontwikkeling van technische beroepen in

4.2 Werkgelegenheidsontwikkeling van technische beroepen in het $\begin{array}{ll}\text { Technogebied } & 47\end{array}$

4.3 Arbeidsmarkt voor technisch opgeleiden in het Technogebied 49

4.4 Conclusies $\quad 58$

5 Overwegingen bij het sluiten of starten van een technische opleiding 61

5.1 Het sluiten van een opleiding 62

5.2 Het starten van een opleiding 63

$\begin{array}{lll}5.3 \text { Conclusies } & 65\end{array}$

6 De keuze voor techniek $\quad 67$

6.1 Deelname aan techniek, economie en zorg per postcodegebied 70

6.2 Achtergrondkenmerken van leerlingen en leerlingenpopulatie per
ROC

6.3 Motieven en achtergronden bij de keuze voor techniek 76

$\begin{array}{lll}6.4 & \text { Conclusies } & 87\end{array}$

7 Conclusies $\quad 91$

$\begin{array}{ll}\text { Referenties } & 95\end{array}$ 
Bijlage 1 Ontwikkeling van het aantal leerlingen en gediplomeerden van aan techniek grenzende opleidingen

Bijlage 2 Afbakening van technische en niet-technische opleidingen

Bijlage 3 Technische MBO-opleidingen in het Technogebied

Zuidoost-Nederland

Bijlage $4 \quad$ Hoofdvestigingen van VMBO-scholen in het Technogebied Zuidoost-Nederland

Bijlage $5 \quad$ HBO-scholen in het Technogebied Zuidoost-Nederland en Zuid-Limburg

Bijlage 6 Afbakening van technische, aan techniek grenzende en overige beroepsgroepen

Bijlage $7 \quad$ Gegevensverzameling op basis van leerlingenadministraties en leerlingenenquête

Bijlage $8 \quad$ Aandeel leerlingen techniek per opleidingslocatie voor vijf ROC's in Technogebied Zuidoost-Nederland

Bijlage 9 Afstand tussen woonadres en opleidingslocatie van eerstejaars leerlingen van vijf ROC's in het Technogebied Zuidoost-Nederland 


\section{Voorwoord}

In Zuidoost-Nederland kiezen relatief méér jongeren voor een technische opleiding dan in de rest van het land. Dit geldt voor de gehele beroepsonderwijskolom van $\mathrm{VMBO}, \mathrm{MBO}$ en $\mathrm{HBO}$. De belangstelling voor een technische opleiding neemt echter ook in deze regio gestaag af. In het $\mathrm{MBO}$ is de dalende trend zelfs sterker dan landelijk. Dit zijn nog maar enkele van de inzichten die ik aan het voorliggende rapport ontleen. Als $\mathrm{u}$ belang hecht aan kennis van de feitelijke situatie in het technisch beroepsonderwijs, nodig ik u uit om méér dan alleen de samenvatting te lezen. Dit rapport bevat immers een schat aan informatie.

Het Technocentrum Zuidoost-Nederland heeft aan de onderzoekers van het ROA gevraagd een regionale kaart van het technisch onderwijs te maken. Door de teruglopende belangstelling staat de instandhouding van de infrastructuur in het technisch beroepsonderwijs onder druk. Het is belangrijk dat de onderwijsinstellingen hiervoor gezamenlijk oog hebben. Om het gesprek over het toekomstperspectief goed te kunnen voeren, zowel tussen instellingen onderling als tussen instellingen en hun regionale partners, is meer inzicht in de feitelijke regionale situatie vereist. Dit is de eerste verdienste van het voorliggende rapport.

De in het Technocentrum samenwerkende ROC's zullen de resultaten van dit rapport gezamenlijk bespreken, om waar nodig en mogelijk afspraken over de spreiding van het opleidingenaanbod te maken. Op voorhand mag duidelijk zijn dat dit onderwerp weliswaar een eerste verantwoordelijkheid van het onderwijs zelf is, maar dat partners in de regio - bedrijfsleven en overheid - hierbij betrokken moeten zijn. Dit rapport kan zonder twijfel een rol gaan spelen in de actuele discussie over de toptechnologische ambities van deze regio. Het Technocentrum hecht daarom belang aan verspreiding van het rapport en staat open voor kritische reacties.

Het Technocentrum Zuidoost-Nederland heeft als doel bij te dragen aan de regionale samenwerking tussen onderwijs en bedrijfsleven. Diverse initiatieven worden ondersteund en bovenregionale problemen worden aangepakt. Het voorliggende rapport is een goed voorbeeld van de wijze waarop over de grenzen heen naar onderwijs gekeken kan worden. Het sluit bovendien aan op het vorig jaar uitgebrachte rapport "Regionale ontwikkelingen en het beroepsonderwijs", waarin de sociaal-economische ontwikkeling van de regio Zuidoost-Nederland is beoordeeld op consequenties voor het beroepsonderwijs.

Namens het bestuur van Technocentrum Zuidoost-Nederland,

Leo Scholl

voorzitter College van Bestuur Gilde Opleidingen 



\section{Samenvatting}

In dit rapport staat de vraag centraal of het aanbod van technische opleidingen op de verschillende locaties van Regionale Opleidingscentra (ROC's) in het Technogebied Zuidoost-Nederland een belemmering vormt voor leerlingen om voor een technische opleiding in het middelbaar beroepsonderwijs te kiezen. Gelet op de verwachte tekorten aan technisch geschoolde arbeidskrachten rijst de vraag of de deelname aan techniek kan worden bevorderd door op meer locaties in het Technogebied technische opleidingen aan te bieden. Hierbij is het van belang dat het aanbieden van technische opleidingen ten opzichte van bijvoorbeeld economische opleidingen duur is. Dit betekent dat een andere formulering van de vraagstelling eveneens van belang is, in het bijzonder voor technische opleidingen, namelijk in welke mate het mogelijk is om technische opleidingen op een beperkt aantal locaties binnen het Technogebied te concentreren zonder dat dit leidt tot een significante daling van de deelname aan techniek.

Uit ons onderzoek blijkt dat het aanbod van technische opleidingen op de verschillende opleidingslocaties in het Technogebied nauwelijks onderdoet voor het aanbod van economische en zorgopleidingen. Hierbij is gekeken naar de opleidinglocaties van de vijf belangrijkste ROC's in het Technogebied Zuidoost-Nederland, te weten ROC Ter Aa, Gilde Opleidingen, ROC Eindhoven, Koning Willem I College en ROC De Leijgraaf. Het blijkt mogelijk te zijn om vanuit elke plaats in het Technogebied op maximaal $30 \mathrm{~km}$. reisafstand een opleidingslocatie van een ROC te bereiken waar een breed scala aan techniekopleidingen wordt aangeboden. Als de $30 \mathrm{~km}$.-grens als maximum reisafstand voor leerlingen wordt gehanteerd, zijn er weinig mogelijkheden voor verdere concentratie van technische opleidingen in het Limburgse deel van het Technogebied en de aangrenzende gebieden. Binnen het Brabantse deel van het Technogebied zijn er wel voedingsgebieden van ROC's die elkaar overlappen.

Om de deelname aan techniek te vergroten zou men zich derhalve veeleer moeten inspannen om bij bepaalde doelgroepen meer interesse voor techniek te wekken, bijvoorbeeld bij vrouwen en allochtonen, dan om het aantal opleidingslocaties met techniek in de regio te vergroten. Mogelijk kunnen ook de vaders van leerlingen die werkzaam zijn in een technisch beroep daarbij nog een sleutelrol vervullen. Van belang is ook de kwaliteit van de instroom om voldoende leerlingen tot niveau 3 of 4 te kunnen opleiden. Ook heeft het binnen het Technogebied meer zin om aandacht te besteden aan de kwaliteit van het aanbod van technische opleidingen dan aan de uitbreiding van het aantal locaties waar techniek wordt aangeboden. Concentratie van dure, maar kwalitatief hoogwaardige technische opleidingen op één locatie is daarbij een reëel alternatief. Op deze wijze kan tegemoet worden gekomen aan de wensen van werkgevers om leerlingen beter op te leiden met competenties die up-todate zijn. 



\section{Inleiding}

Afgestudeerden van het technisch onderwijs vormen een essentiële factor voor de Nederlandse economie van de nabije toekomst. Nederland streeft naar een kenniseconomie. De kennis van werknemers, die door hun opleiding en hun functioneren bijdragen aan de continue innovatie van producten en bedrijfs-processen, wordt daarmee steeds belangrijker. En zo ook de dragers van die kennis, de kenniswerkers. Al in het ontwerp Hoger onderwijs en onderzoeksplan 1998 wordt gesteld dat "De behoefte van het bedrijfsleven aan bèta- en technisch gekwalificeerden stijgt vanwege het toenemend belang van hoogwaardige technologische kennis voor de postindustriële productie en dienstverlening" (OCW, 1997). Het MBO vervult een belangrijke rol bij zowel het opleiden van leerlingen voor de arbeidsmarkt als bij de doorstroom van MBO-gediplomeerden naar het hoger beroepsonderwijs. In 2002 had $38 \%$ van de werkzame beroepsbevolking een MBO-opleiding (CBS, Statline). Meer dan de helft van MBO-leerlingen op niveau 3 en $4^{1}$ begint na afronding met een vervolgopleiding op HBO-niveau (Van Eijs, 2003).

De schaarste aan kenniswerkers speelt breed. Volgens het Innovatieplatform (2003) is er op middelbaar en hoger niveau schaarste aan technici. Volgens het platform zorgen tekorten aan bèta's en technici voor een onzekere toekomst. Dit omdat juist bèta's en technici van cruciaal belang zijn voor het ontwikkelen en toepassen van technologische innovaties en daarnaast ook in veel andere sectoren, zoals de zorg of het onderwijs, een belangrijke rol spelen. De tekorten aan bèta's en technici zijn merkbaar in de markt, bij onderzoeksinstellingen en bij de overheid. Ook internationaal gezien blijft de belangstelling voor technische opleidingen in ons land achter (Innovatieplatform, 2003).

Uit het bovenstaande volgt dat het van belang is om meer inzicht te krijgen in de vraag hoe jongeren kunnen worden gestimuleerd om technisch onderwijs te volgen. Alle promotiecampagnes ten spijt, lijkt vooralsnog de populariteit van het technisch onderwijs te dalen. Het ziet ernaar uit dat hierdoor het aanbod van technisch opgeleide schoolverlaters op de arbeidsmarkt in de komende jaren zal achterblijven bij de vraag naar technici (ROA, 2003). Dit geldt in het bijzonder voor technisch opgeleiden van het middelbaar en hoger beroepsonderwijs (MBO en HBO), en van het wetenschappelijke onderwijs (WO).

Een afnemende belangstelling van jongeren voor het volgen van een technische opleiding, in combinatie met de schaalvergroting in het middelbaar beroepsonderwijs, kan ertoe leiden dat er op steeds minder locaties in Nederland nog technische opleidingen worden aangeboden. In dit onderzoek wordt de ruimtelijke spreiding van het middelbaar technisch beroepsonderwijs in de regio van het Technocentrum Zuidoost-Nederland (het 'Technogebied') nader onderzocht. Het gaat daarbij om het

1. Dit zijn volgens de Wet Educatie en Beroepsonderwijs (WEB) MBO-leerlingen met een vakopleiding (kwalificatieniveau 3) of een middenkader/specialistenopleiding (kwalificatieniveau 4). 
aanbod van technische beroepsopleidingen door de onderwijsinstellingen in OostBrabant, Noord- en Midden-Limburg. Bovendien wordt ingegaan op het opleidingenaanbod in de aangrenzende gebieden van het Technogebied, dat wil zeggen delen van Brabant en Gelderland, Zuid-Limburg, en de Belgische grensstreek (in het bijzonder Maaseik). Er zal aan de hand van twee case studies worden ingegaan op de voor- en nadelen van het spreiden dan wel concentreren van het aanbod van technische opleidingen op één of meerdere locaties.

De centrale vraag is of en in welke mate een groter aantal technieklocaties de deelname aan technisch onderwijs kan bevorderen, en welke invloed de concentratie van technische opleidingen op één of enkele locaties heeft op de deelname aan technisch onderwijs. Daartoe zal worden bekeken hoe de keuze voor techniek door leerlingen in de verschillende deelgebieden in het Technogebied uitvalt. Bovendien wordt bekeken of de studiekeuze samenhangt met de afstand tot de opleidingslocaties, en met het onderwijsaanbod op deze locaties. Hierbij wordt gebruik gemaakt van gegevens uit de leerlingenadministraties van vijf ROC's in het Technogebied. Door gebruik te maken van de uitkomsten van een leerlingenenquête wordt bovendien het belang nagegaan van de afstand en de reistijd van thuis naar school ten opzichte van de interesse voor het beroep, de aantrekkelijkheid van de school, en de aantrekkelijkheid van de omgeving van de school.

Om de keuze voor techniek door leerlingen in het Technogebied in perspectief te kunnen plaatsen, zal er een 'regionale kaart van het technisch beroepsonderwijs' worden samengesteld. Hierbij zal de ruimtelijke spreiding van het opleidingenaanbod worden geïnventariseerd, dat wil zeggen welke ROC's in het Technogebied en de aangrenzende gebieden technische opleidingen aanbieden. Tevens wordt er op systematische wijze de ontwikkeling van de deelname aan techniekonderwijs weergegeven, alsmede de doorstroom binnen de beroepskolom (van VMBO naar HBO) en de aansluiting tussen het technisch beroepsonderwijs en de regionale arbeidsmarkt. Er zal waar mogelijk onderscheid worden gemaakt tussen niveau, richting en leerweg van de technische beroepsopleidingen. Bovendien zal telkens een vergelijking worden gemaakt tussen het Technogebied en Nederland, en tussen techniek en niet-techniek.

Om meer grip te krijgen op de ernst van de knelpunten op de arbeidsmarkt voor technici in het Technogebied, wordt gekeken naar hoe het aanbod van technisch opgeleiden aansluit bij de vraag. Er wordt een vergelijking gemaakt tussen het Technogebied en Nederland voor techniek en niet-techniek aan de hand van schoolverlatersgegevens over de aansluiting tussen onderwijs en arbeidsmarkt. Bovendien worden gegevens over de werkgelegenheid naar beroep en opleiding gebruikt om de ontwikkeling over de tijd in het Technogebied en Nederland weer te geven. Limburg en het oosten van Noord-Brabant zijn van oudsher gebieden waarin de industrie sterk vertegenwoordigd is. Ook in het Technogebied is de industrie van groot belang, zoals valt af te lezen uit de aanwezigheid van bedrijven als Philips, Océ, Daf en ASML. Te verwachten valt dat daardoor ook het technisch onderwijs in dit gebied oververtegenwoordigd is, dat er relatief veel mensen een technische opleiding volgen en dat de werkgelegenheid in de technische beroepen is oververtegenwoordigd. 
In hoofdstuk 2 wordt de regionale kaart van het middelbaar technisch beroepsonderwijs in het Technogebied besproken. Hierbij wordt zowel de deelname aan het MBO als de uitstroom uit het MBO vergeleken met Nederland. In hoofdstuk 3 wordt nader ingegaan op de doorstroom binnen de beroepskolom en de arbeidsmarktintrede. In dit hoofdstuk wordt de uitstroom uit het VMBO en de instroom in het HBO weergegeven. Ook wordt gekeken naar de vooropleiding van MBO'ers en HBO'ers, en hun aansluiting tussen opleiding en beroep. In hoofdstuk 4 komt de ontwikkeling van de werkgelegenheid van de technische beroepen en de arbeidsmarktpositie van technisch opgeleiden in Nederland en het Technogebied aan de orde. Er wordt gedifferentieerd naar de werkgelegenheid in de technische beroepen en twee aangrenzende beroepsgroepen. De arbeidsmarktpositie van technisch opgeleiden wordt afgemeten aan de werkloosheid, de non-participatie en het werken buiten de eigen vakrichting (i.e. buiten een technisch beroep). In hoofdstuk 5 worden twee case-studies besproken over het stopzetten en het opstarten van een nieuwe opleiding. Dit geeft inzicht in de afwegingen die ROC's maken bij het vaststellen van hun opleidingenaanbod. In hoofdstuk 6 wordt een analyse van de invloed van de reisafstand tussen woonadres en opleidingslocatie op de keuze voor techniek gegeven. Hierbij worden twee bronnen gebruikt, namelijk leerlinggegevens uit de administraties van de vijf grote ROC's in het Technogebied (Gilde Opleidingen, ROC Eindhoven, ROC Ter AA, Koning Willem I College en ROC de Leijgraaf) en de enquêteresultaten van een steekproef van leerlingen aan vier van deze ROC's. In hoofdstuk 7 volgen de conclusies.

Het Technocentrum Zuidoost-Nederland (ZON) is opdrachtgever van het onderzoek. Technocentrum Zuidoost-Nederland is een stichting die zich ten doel stelt relatieversterking en kennisuitwisseling tussen onderwijs en bedrijfsleven. De projectleiding van het onderzoek was in handen van F. Cörvers. Aan het onderzoek hebben meegewerkt J. Coenen, S. Dijksman, M. Hensen, H. Heijke en R. Montizaan.

De begeleidingscommissie van het onderzoek bestond naast de voorzitter S. Strous (Technocentrum Zuidoost-Nederland en ROC Eindhoven) en de secretaris $T$. Berkers (Gilde Opleidingen) uit P. Apeldoorn (Provincie Noord-Brabant), P. Bertens (Kamer van Koophandel Limburg-Noord), H. Dierx (Gemeente Weert), L. de Veen (Raayland College), T. Verhoeven (ROC Ter Aa), en J. Vonk (Fontys Pedagogisch Technische Hogeschool). Wij danken de leden van de begeleidingscommissie voor het commentaar op de analyses en de ondersteuning bij het onderzoek. Verder danken wij L. Scholl (Gilde Opleidingen) voor de ondersteuning bij de aanvang van het onderzoek. Voor het verstrekken van gegevens over leerlingen van het Technisch Instituut Sint-Jansberg in Maaseik zijn wij dank verschuldigd aan L. Vos (TI Sint-Jansberg). Voor de medewerking aan de interviews ten behoeve van de case-studies bedanken wij F. Liebregts (Schildersvakcentrum Nuenen) en L. Laros (Gilde Opleidingen).

Voor de aanlevering van gegevens uit de leerlingenadministratie en de medewerking aan de leerlingenenquête via de ROC Spiegel bedanken wij L. Swinkels, J. Aerts, A. Kleijnen, J. Kerkhof, K. Say, T. van de Laar (allen Gilde Opleidingen), G. van Beers, C. Moes, C. Damen, H. Bataille, H. Jeurissen, M. van der Palen, P. Sanders (allen 
ROC Eindhoven), R. v.d. Sande (ROC Ter AA), S. van Oorschot, J. Lindeloof, J. Schobben (allen ROC de Leijgraaf), E. van Woesik, O. Swiers, C. van Gerven, A. van Kroonenburg, C. Diepstraten, K. Mathijsen, en M. Kuipers (allen Koning Willem I Colllege). Ook bedanken wij de medewerkers van Bureau Digidoc (B. Borm en B. Janss) voor de uitvoering van de leerlingenenquête met de ROC Spiegel. 


\section{Regionale kaart van het middelbaar technisch beroepsonderwijs}

In dit hoofdstuk wordt het middelbaar technisch beroepsonderwijs (MBO) in kaart gebracht voor het gebied van het Technocentrum Zuidoost-Nederland (ZON). Dit gebied wordt hier kortweg als 'Technogebied' aangeduid. Voor zowel Nederland als het Technogebied wordt gekeken naar drie factoren die de ontwikkeling van het aantal leerlingen in het middelbaar technisch beroepsonderwijs kunnen verklaren. Ten eerste speelt het aantal jongeren in de leeftijdsklasse van 15-24 jaar een rol. Hoe meer jongeren er zijn, hoe groter het potentieel aan leerlingen dat voor techniek zou kunnen kiezen. Ten tweede het aantal jongeren dat voor middelbaar beroepsonderwijs kiest. Ook hiervoor geldt dat een toename van het aantal leerlingen in het MBO, een groter potentieel genereert aan leerlingen dat voor het middelbaar technisch beroepsonderwijs zou kunnen kiezen. Ten derde speelt de populariteit van techniekopleidingen onder jongeren die voor het MBO kiezen een rol. Hoe groter deze populariteit is, hoe groter het aandeel jongeren dat een technische opleiding volgt in het middelbaar beroepsonderwijs.

Om de ontwikkeling van het aantal leerlingen in beeld te brengen, wordt gebruik gemaakt van gegevens van het Centraal Bureau voor de Statistiek (CBS). ${ }^{2}$ Deze gegevens zijn gebaseerd op de oktobertellingen die onderwijsinstellingen aanleveren aan het Ministerie van OCW. De afbakening van technisch onderwijs is gebeurd op basis van de SOI-classificatie van het CBS (zie Bijlagen 1 en 2). De regionale gegevens hebben betrekking op de Coropgebieden ${ }^{3}$ Noordoost-Noord-Brabant, ZuidoostNoord-Brabant, Noord-Limburg en Midden-Limburg. Gegevens over leerlingen en gediplomeerden zijn echter alleen beschikbaar per hoofdvestiging, waardoor leerlingen en gediplomeerden worden toegerekend aan het Coropgebied waarin de hoofdvestiging zich bevindt. Dit probleem ondervangen we door alleen aantallen leerlingen weer te geven voor het totaal van de vier Corop-gebieden, die samen het Technogebied Zuidoost-Nederland vormen.

In paragraaf 2.1 komt de spreiding van ROC's in Nederland en het Technogebied aan de orde. Hierbij wordt in het bijzonder gekeken naar de spreiding van het opleidingenaanbod van middelbare technische beroepsopleidingen in het Technogebied en aangrenzende gebieden. In paragraaf 2.2 en 2.3 wordt de deelname aan het (technisch) onderwijs besproken voor respectievelijk Nederland als geheel en voor het Technogebied afzonderlijk.

2. Zie http://www.cbs.nl. We hebben echter vooral de microbestanden van het CBS gebruikt om zelf selecties op opleidingen en regio's te kunnen uitvoeren.

3. De indeling in 40 Coropgebieden is omstreeks 1970 ontworpen door de Coördinatie Commissie Regionaal Onderzoeksprogramma (COROP) en omvat een verdeling van gebieden binnen een provincie op basis van een nodale hiërarchie. 
De vergelijking met Nederland is van belang om vast te stellen of, en in welke mate, de ontwikkelingen in het Technogebied afwijken van die in Nederland. In paragraaf 2.4 wordt gekeken in welke mate het aanbod van technische opleidingen in Vlaanderen - in het bijzonder in Maaseik - relevant is voor Nederlandse leerlingen die een technische opleiding willen kiezen. Op basis van de eerder genoemde CBS-gegevens wordt in paragraaf 2.5 de ontwikkeling van het aantal leerlingen uitgesplitst naar deelsectoren van het technische middelbaar beroepsonderwijs. In paragraaf 2.6 volgen de conclusies.

\subsection{Spreiding van opleidingslocaties in het MBO}

tot 1998 zijn veel kleinere scholen gefuseerd tot grote Regionale Opleidingscentra (ROC's), zoals Gilde Opleidingen in Noord- en Midden-Limburg, en ROC Eindhoven en ROC Ter AA in het oosten van Noord-Brabant. In de jaren tachtig waren er nog rond de 1.500 scholen, die opleidingen in de BVE- sector ${ }^{4}$ aanboden. Figuur 2.1 laat zien dat er nu nog slechts 71 BVE-instellingen in Nederland zijn, waarvan 42 ROC's en 11 AOC's (Agrarische OpleidingsCentra). Deze afname is vooral veroorzaakt door een aantal fusierondes, waarbij vele kleinere ROC's in een grootschalige BVEinstelling zijn opgegaan. Hierbij is een deel van deze ROC's blijven voortbestaan als nevenlocatie van de overkoepelende BVE-instelling. Duidelijk is dat er sinds de jaren tachtig steeds minder instellingen zijn die MBO-opleidingen aanbieden. Dit hoeft echter niet te betekenen dat er minder MBO-opleidingen in de verschillende regio's worden aangeboden.

Figuur 2.1

Ontwikkeling van het aantal BVE-instellingen in Nederland, 1993-2004

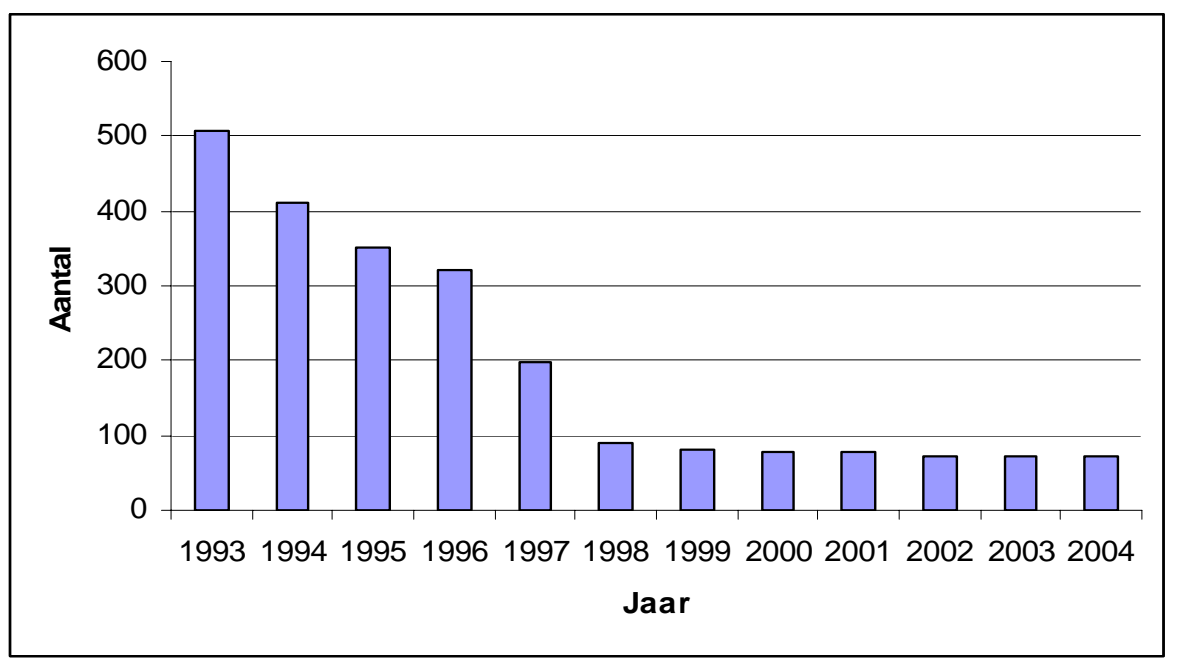

Bron: ROA / BVE-Raad

4. De sector Middelbaar Beroepsonderwijs en VolwassenenEducatie (BVE).

6 
Figuur 2.2

Spreiding van BVE-instellingen in Nederland, hoofdvestigingen van ROC's, AOC's en vakscholen (voor zover zelfstandig volgens opgave van de BVE Raad), 2005

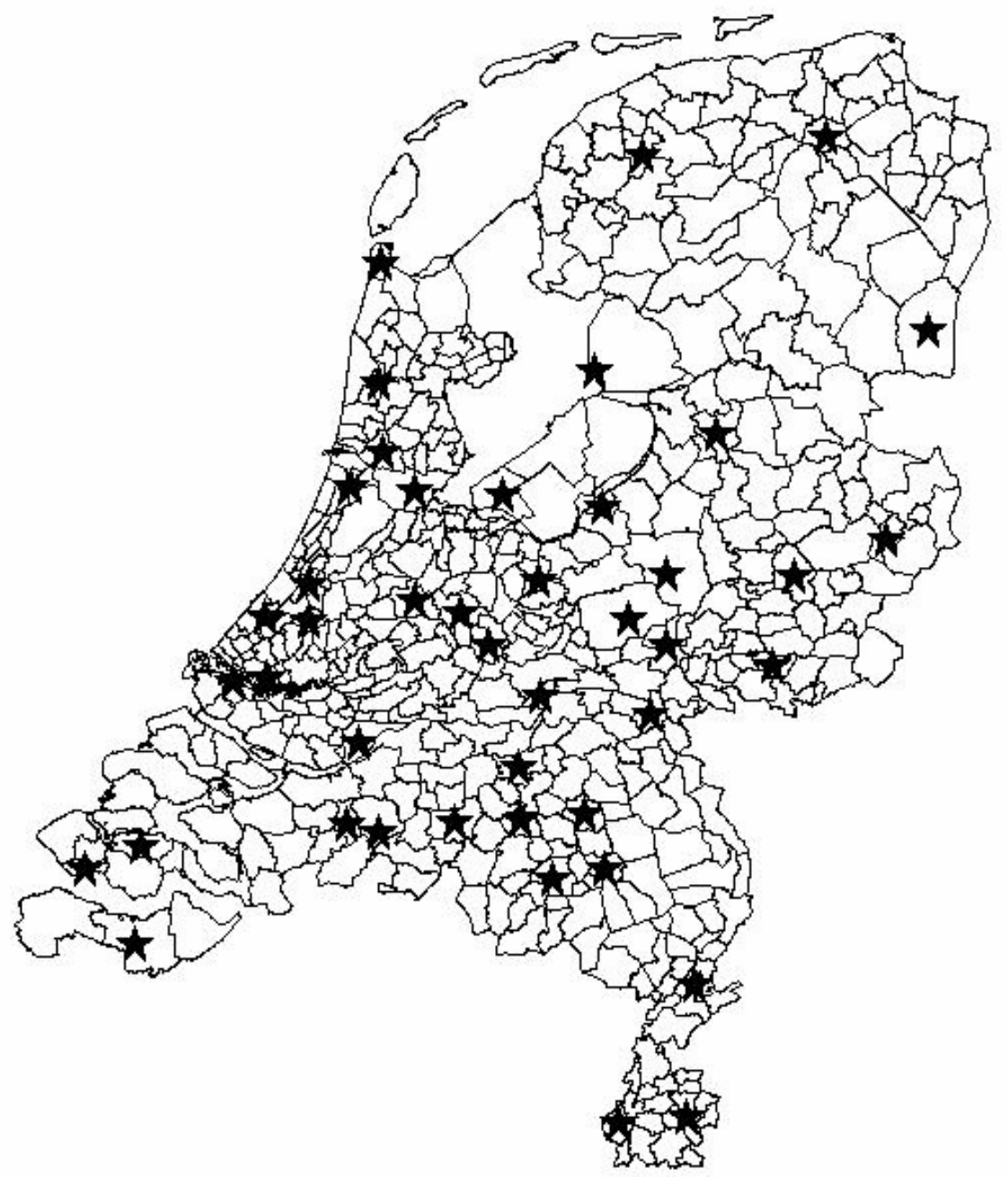

Bron: ROA / BVE Raad

Door het kleinere aantal BVE-instellingen is het aantal leerlingen per instelling groter geworden. Gemiddeld heeft een BVE-instelling thans ongeveer 9.000 leerlingen. Aangezien het aantal BVE-instellingen tot 1998 drastisch is afgenomen, is het van belang te weten of ook de regionale spreiding over Nederland van de locaties waar onderwijs wordt aangeboden is afgenomen. Indien geslaagden van HAVO (Hoger Algemeen Voortgezet Onderwijs) of VMBO (Voorbereidend Middelbaar Beroeps Onderwijs) een bepaalde MBO-opleiding willen volgen - terwijl deze opleiding niet in de directe omgeving aangeboden wordt - zullen ze mogelijk een andere MBOopleiding overwegen. Een onevenwichtige spreiding van het aanbod van technische 
MBO-opleidingen over Nederland zou dan kunnen leiden tot een afname van het aantal technisch opgeleide MBO'ers.

Figuur 2.2 geeft een indicatie van de spreiding van BVE-instellingen binnen Nederland. In de figuur zijn alleen de hoofdvestigingen van de Nederlandse ROC's, AOC's en vakscholen opgenomen. In veel gemeentes huisvest slechts één BVEinstelling, terwijl gemeentes zoals Utrecht en Leeuwarden drie zelfstandige instellingen hebben. Groningen en Zwolle hebben vier BVE-instellingen in hun gemeente. Rotterdam biedt zelfs plaats aan vijf BVE-instellingen. Wat opvalt, is dat vooral in het noordoosten van het land de spreiding van BVE-instellingen erg laag is. In en rondom de grote steden (Amsterdam, Rotterdam, Utrecht, Nijmegen/Arnhem, Eindhoven/Tilburg) zijn veel BVE-instellingen dicht bij elkaar gevestigd.

Figuur 2.3 geeft een beeld van de spreiding van technische MBO-opleidingen binnen het Technogebied Zuidoost-Nederland. Het gaat hierbij om zowel hoofd- en nevenvestigingen als vakscholen en opleidingsbedrijven, die vaak vallen onder of samenwerken met een groot ROC. In Bijlage 3 bij dit rapport wordt een uitgebreid overzicht gegeven van de verschillende locaties waar technische opleidingen in het Technogebied worden aangeboden.

Opvallend is dat in het Coropgebied Zuidoost-Noord-Brabant de locaties met technische opleidingen in en rondom Eindhoven geconcentreerd zijn. Daarentegen zijn de opleidingslocaties in het Coropgebied Noordoost-Noord-Brabant redelijk goed gespreid. Toch worden de meeste opleidingen in slechts enkele gemeentes aangeboden. Zo zijn er in Eindhoven ongeveer 150 technische opleidingen (vooral aangeboden door ROC Eindhoven), ${ }^{5}$ in 's Hertogenbosch ca. 105 technische opleidingen (Koning Willem I College), Helmond heeft ca. 75 technische opleidingen (ROC Ter $\mathrm{Aa}$ ) en in Veghel worden ongeveer 85 technische opleidingen aangeboden (ROC de Leijgraaf). In Rosmalen (gemeente 's-Hertogenbosch), Boxtel, Nuenen, Mierlo en Veldhoven wordt een beperkt aantal technische opleidingen aangeboden. In het Limburgse deel van het Technogebied is de dichtheid van de locaties waar technische opleidingen worden aangeboden kleiner dan in het Noord-Brabantse deel. Uit de kaart blijkt dat er opleidingen in Roermond, Venlo, Weert, Horst en Venray worden aangeboden. In Roermond en Venlo worden ongeveer 85 opleidingen aangeboden (Gilde Opleidingen). In Weert, Horst en Venray is het opleidingenaanbod echter zeer beperkt (zie Bijlage 3). Een breed opleidingenaanbod is alleen beschikbaar in Roermond en Venlo. Derhalve zou een deel van de jongeren in de perifere gebieden in Noord- en Midden-Limburg met interesse voor techniek kunnen kiezen voor de ROC's in Noord-Brabant, Zuid-Limburg, Gelderland of België (zie paragraaf 2.4).

5. Hier worden alleen de vijf grote ROC's in Technogebied Zuidoost-Nederland genoemd. Zie verder Bijlage 3. 
Figuur 2.3

Spreiding van locaties met technische MBO-opleidingen in het Technogebied Zuidoost-Nederland $^{6}, 2005$

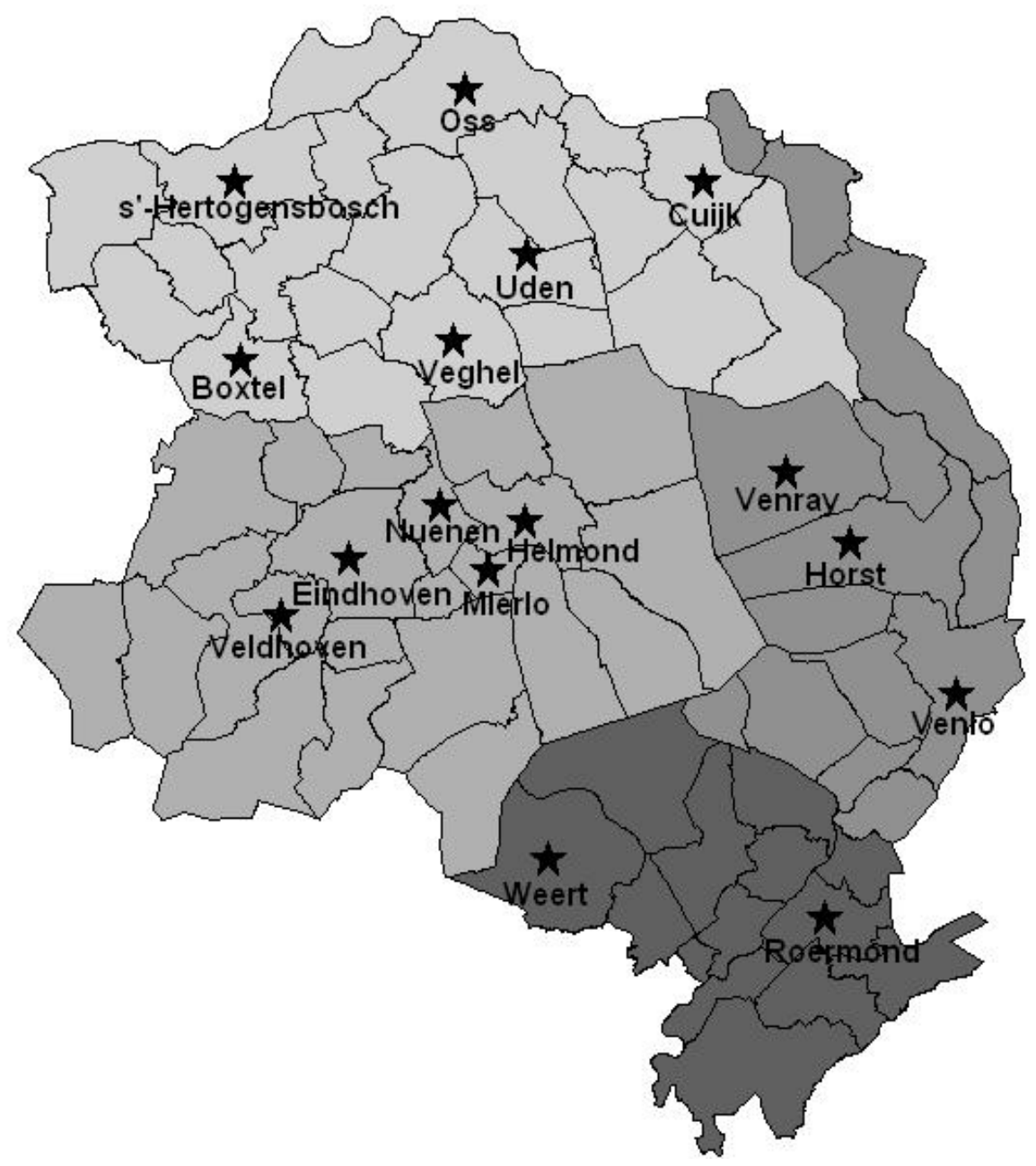

Bron: ROA

Er blijken enkele technische MBO-opleidingen te zijn die niet in het Technogebied worden aangeboden. Zo wordt de opleiding landmeetkunde niet aangeboden in het Technogebied. Van de deelsector Werktuigbouwkunde wordt de opleiding vliegtuigbouwkunde niet aangeboden en van grafische techniek kan de opleiding papierverwerking/veredeling niet gevolgd worden in het Technogebied. Van Proces-

6. In de figuur zijn de gemeentes weergegeven waar technische opleidingen worden aangeboden. Het betreft daarbij technische opleidingen binnen hoofdvestigingen van ROC's, maar ook nevenvestigingen van ROC's, opleidingsbedrijven en vakscholen. In veel gevallen zijn er samenwerkingsverbanden tussen de opleidingsbedrijven en vakscholen enerzijds en één of meerdere ROC's anderzijds. Zie Bijlage 3 bij dit rapport voor een uitgebreid overzicht van alle locaties met technische opleidingen in het Technogebied. 
Figuur 2.4

Ligging van ROC's (hoofd- en nevenvestigingen) met technische opleidingen in de aangrenzende Coropgebieden ${ }^{7}, 2005$

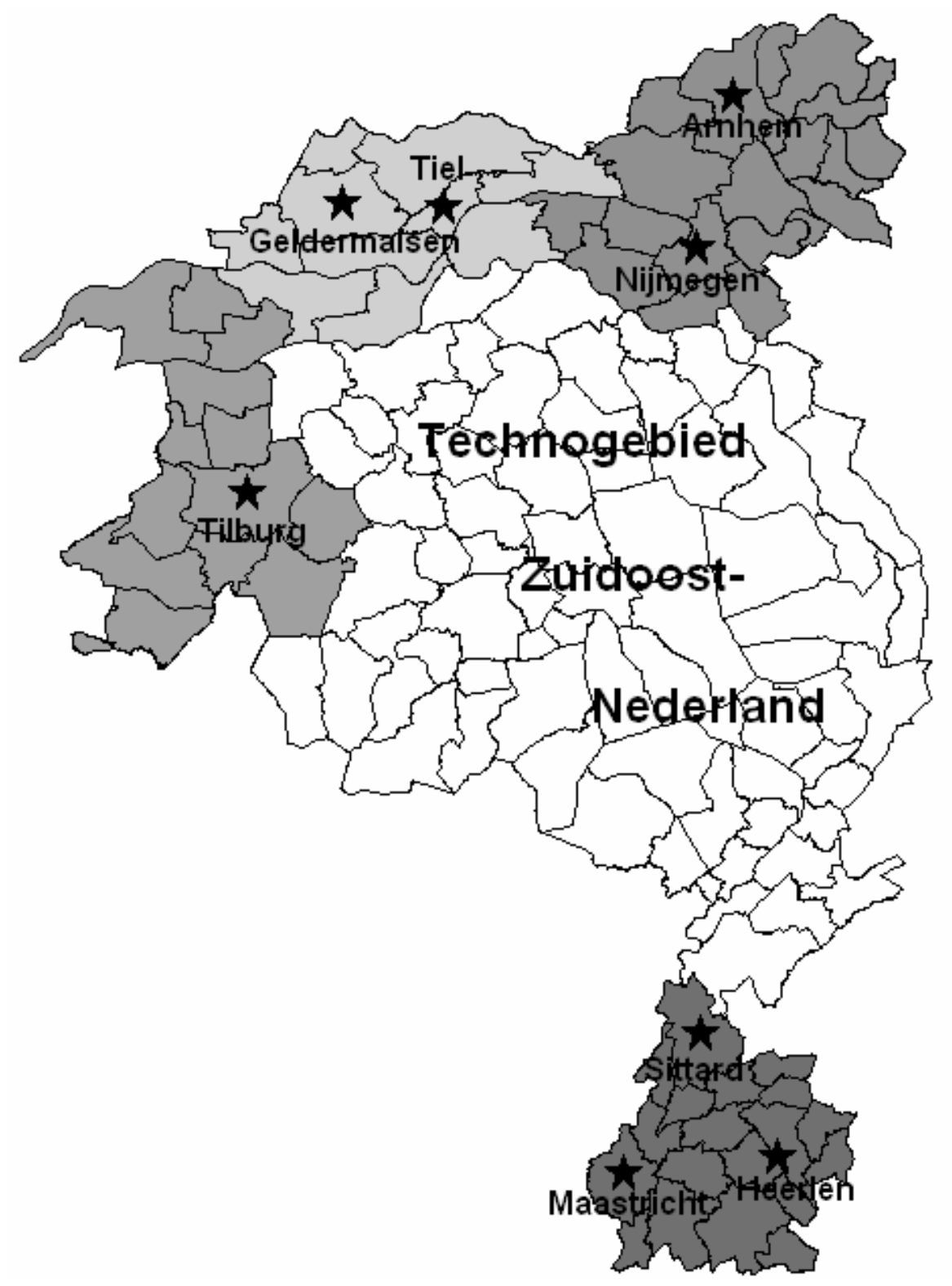

Bron: ROA

techniek worden vier van de acht bestaande opleidingen niet aangeboden, onder andere metallurgie/keramiek, papier/strokarton/rubber en petrochemie/kunststoffen. Uit de deelsector Techniek Overig wordt alleen de opleiding textiel- en leerverwer-

7. Tilburg heeft naast een ROC met technische opleidingen ook een vakschool waar techniek wordt gegeven. 
king aangeboden. Tevens wordt maar een deel van de opleidingen waarbij techniek wordt gecombineerd met economisch/administratief en commercieel onderwijs aangeboden. Slechts 8 van de 26 bestaande combinatie-opleidingen zijn te volgen in het Technogebied.

Figuur 2.4 geeft ook de Coropgebieden weer die grenzen aan het Technogebied Zuidoost-Nederland. In de aangrenzende Coropgebieden worden technische opleidingen aangeboden in ROC's die een hoofdvestiging hebben in Tilburg, Arnhem, Nijmegen, Maastricht, Heerlen en Tiel, of een nevenvestiging in Sittard-Geleen en Geldermalsen. Vooral voor de leerlingen van gemeentes die grenzen aan deze vier Coropgebieden kunnen de aangeboden technische opleidingen in deze steden een alternatief zijn. Dit geldt in het bijzonder als het aanbod van technische opleidingen in de grensstreken van het Technogebied Zuidoost-Nederland niet toereikend is. Een andere mogelijkheid voor jongeren is om uit te wijken naar België, naar het Technische Opleidingsinstituut Sint-Jansberg in Maaseik (zie paragraaf 2.4). Dit ligt enkele kilometers ten westen van de gemeente Echt-Susteren, de meest zuidelijke gemeente van het Technogebied in figuur 2.4.

\subsection{Deelname aan MBO techniek in Nederland}

Om de populariteit van het technisch onderwijs te kunnen bepalen wordt eerst gekeken naar de ontwikkeling van het totale aantal MBO-leerlingen gedurende de afgelopen jaren. Onder de MBO-leerlingen worden verstaan degenen die ingeschreven zijn bij een Middelbare Beroepsopleiding. Hieronder vallen zowel de BeroepsOpleidende Leerweg (BOL) als de BeroepsBegeleidende Leerweg (BBL). Het totale aantal MBO-leerlingen ${ }^{8}$ in Nederland is in de afgelopen zeven jaar gestaag toegenomen. Deze toename volgt op een daling in de eerste helft van de jaren negentig. $\mathrm{Er}$ zijn nu ongeveer $480.000 \mathrm{MBO}$-leerlingen in Nederland. Dit komt neer op bijna de helft van alle Nederlandse jongeren tussen 15 en 19 jaar. $^{9}$

Figuur 2.5 laat zien dat er vanaf het schooljaar 1999/2000 sprake was van een stijging van het totale aantal MBO-leerlingen. Dit zou te maken kunnen hebben met de invoering van het $\mathrm{VMBO}^{10}$, die erop was gericht om de aansluiting tussen $\mathrm{VMBO}$ en $\mathrm{MBO}$ te verbeteren. In figuur 2.5 is ook onderscheid gemaakt naar leerweg. Het aantal BOL-leerlingen was in de weergegeven periode ongeveer 300.000. Na een lichte daling begon het aantal BOL-leerlingen vanaf 2000/'01 weer te stijgen. Ongeveer één van de drie leerlingen volgt de beroepsbegeleidende leerweg. De toename van het totaal aantal leerlingen in het MBO kan voor een groot deel

8. De aantallen leerlingen en gediplomeerden worden jaarlijks door iedere BVE-instelling in oktober geteld en aan Cfi (gelieerd aan Ministerie van OCW) doorgegeven. De Cfigegevens worden vervolgens door het CBS aangevuld en bewerkt. Het betreft in dit onderzoek leerlingen en gediplomeerden van het reguliere Middelbare Beroepsonderwijs exclusief de opleidingen en cursussen in het kader van de Volwasseneneducatie.

9. Een deel van de MBO-leerlingen is echter ouder dan 19 jaar.

10. Per 1 augustus 1999 zijn VBO, MAVO en sommige vormen van voortgezet speciaal onderwijs samengevoegd tot het VMBO, het Voorbereidend Middelbaar BeroepsOnderwijs. Deze vernieuwing is erop gericht de aansluiting tussen het voormalige MAVO/VBO/ VSO op het Middelbaar Beroeps Onderwijs (MBO) te verbeteren. 
toegeschreven worden aan een stijging van het aantal BBL-leerlingen. Hierbij kan ook de in deze periode sterk aantrekkende conjunctuur een rol spelen. Een aanwijzing voor de relatie met de conjunctuur is ook de daling van het aantal BBLleerlingen in het schooljaar 2003/'04.

Figuur 2.5

Aantal leerlingen in MBO-opleidingen in Nederland, totaal en naar leerweg, 1997/'98-2003/'04

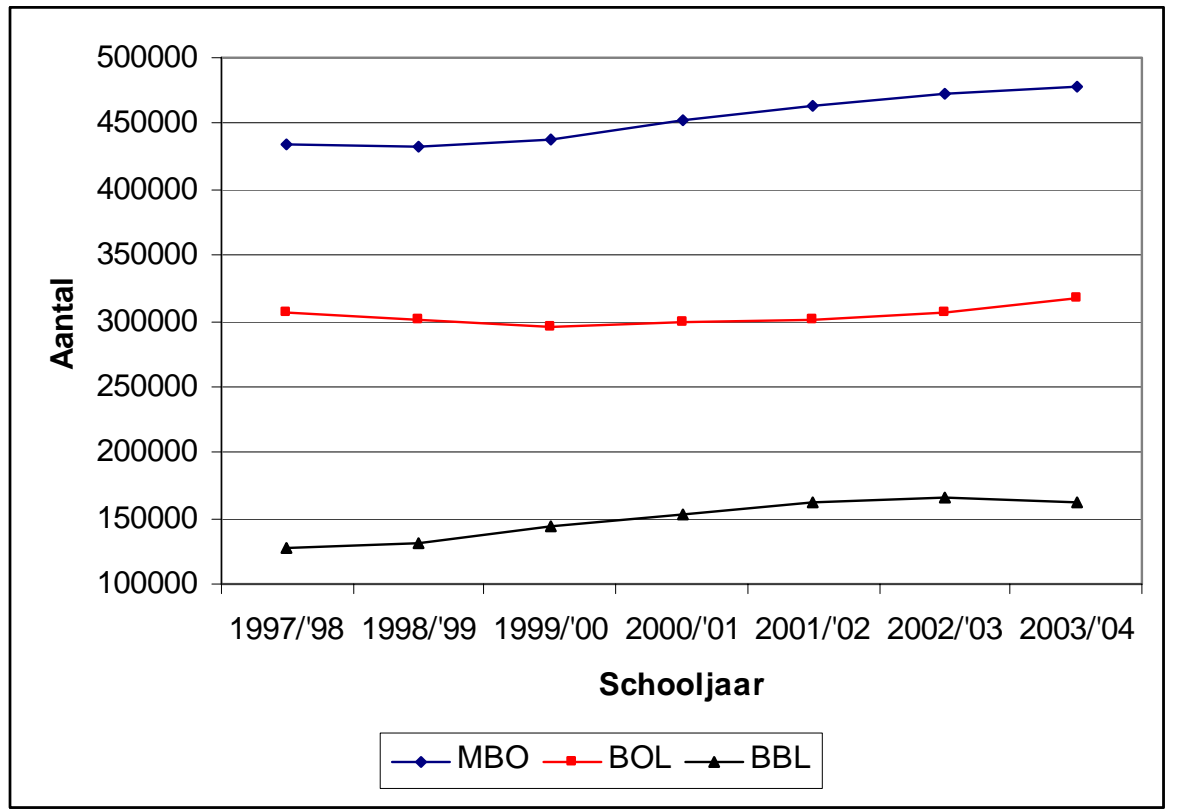

Bron: ROA/CBS

Verder wordt het verloop van het aantal MBO-leerlingen vooral door demografische factoren bepaald. Als er meer jongeren tussen de 15 en 24 jaar zijn, zullen er vanzelf ook meer MBO-leerlingen zijn. Om hierin meer inzicht te krijgen wordt in figuur 2.6 het totale aantal 15-19 en 20-24 jarigen weergegeven. Uiteraard is het verloop van het aantal 20-24 jarigen een min of meer vertraagde weergave van het verloop van het aantal 15-19 jarigen. De omvang van de leeftijdsklasse van 15-19 jarigen daalt aanvankelijk, maar stijgt na 2000 weer. Deze groep vormt het belangrijkste potentieel voor het MBO. De omvang van de leeftijdsklasse van 20-24 jarigen daalt sterker, maar deze groep heeft een veel kleiner aandeel in de populatie MBO-leerlingen, en stabiliseert min of meer vanaf 1999. De stijging van het aantal MBO-leerlingen gedurende de laatste jaren zou deels kunnen worden verklaard door de toename van het aantal jongeren na 2000 . 
Figuur 2.6

Ontwikkeling van het aantal 15-24 jarigen in de Nederlandse bevolking, 1990-2004

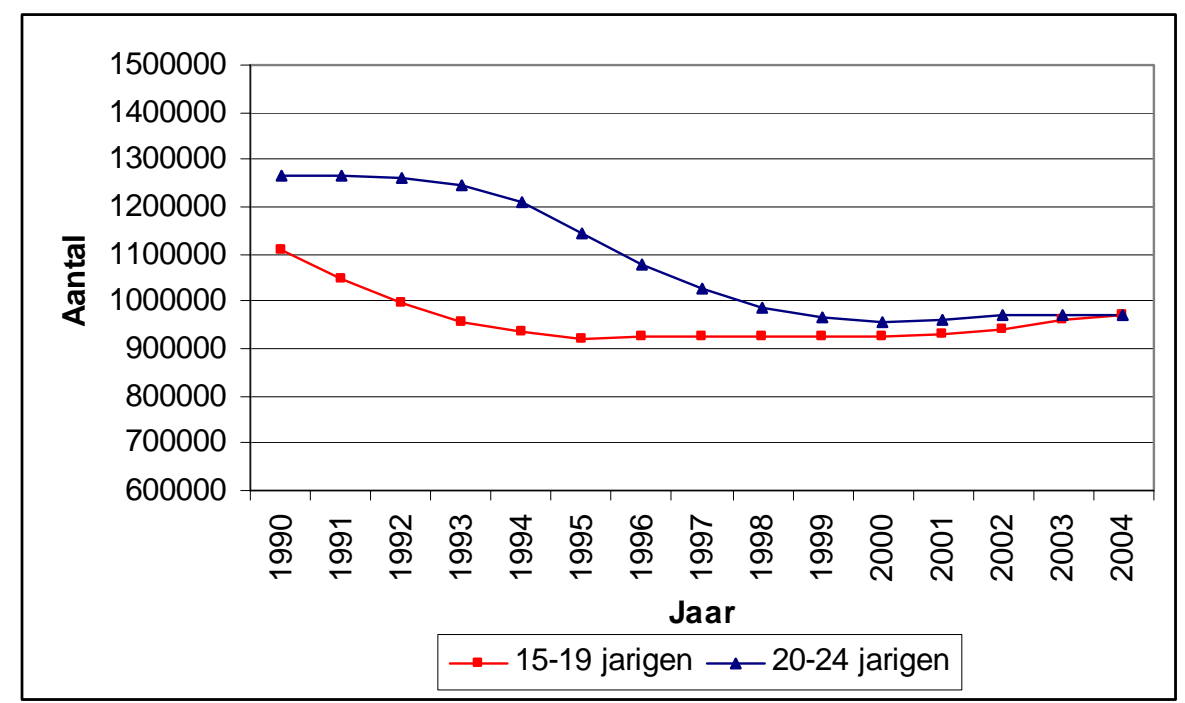

Bron: ROA/CBS

In figuur 2.7 wordt de deelname van MBO-leerlingen aan techniekonderwijs weergegeven. De figuur laat een duidelijke daling zien van het aantal leerlingen dat een MBO-opleiding in de sector techniek volgt. Het is duidelijk dat techniek nu minder populair is onder scholieren dan zeven jaar geleden. In figuur 2.7 is ook het verloop van het aantal BOL- en BBL-leerlingen uit de sector techniek te zien. Hieruit blijkt dat de daling van de MBO-leerlingen techniek volledig aan een daling van het aantal BOL-leerlingen is toe te schrijven. Het aantal BBL-leerlingen steeg tussen 1997/'98 en 2002, maar daalde in de afgelopen twee schooljaren weer naar het niveau van 1997/'98. Ook hier kan worden opgemerkt dat de ontwikkeling van het aantal BBLleerlingen mogelijk verband houdt met de conjunctuur. Omdat werkgevers in een laagconjunctuur minder behoefte hebben aan personeel, zullen zij ook geneigd zijn minder BeroepsPraktijkVormings(BPV)-plaatsen te creëren, waarin leerlingen werken en leren kunnen combineren. Een aanwijzing hiervoor is dat leerlingen in het schooljaar 2003/'04 bij gebrek aan deze BPV-plaatsen in de BBL weer meer kiezen voor de BOL. Voor deze leerlingen is de BOL dus een vluchtroute om toch technisch onderwijs te kunnen genieten.

Overigens kan de daling van het totaal aantal leerlingen techniek vooral worden toegeschreven aan de omstandigheid dat steeds minder jongens voor techniek kiezen. Daarentegen is het aantal vrouwelijke leerlingen in het middelbaar technisch beroepsonderwijs niet veel veranderd tussen 1990/1991 en 2003/'04. Waarschijnlijk leidt de daling van de populariteit van techniek vooral onder jongens die twijfelen over hun studiekeuze (de 'marginale' studiekiezers) tot het kiezen van een andere richting. De weinige meisjes die voor techniek kiezen - ongeveer $11 \%$ van het totaal aantal leerlingen techniek - doen dit over het algemeen zeer bewust. 
Figuur 2.7

Totaal aantal leerlingen in technische MBO-opleidingen in Nederland, uitgesplitst naar BOL en BBL, 1997/'98-2003/'04

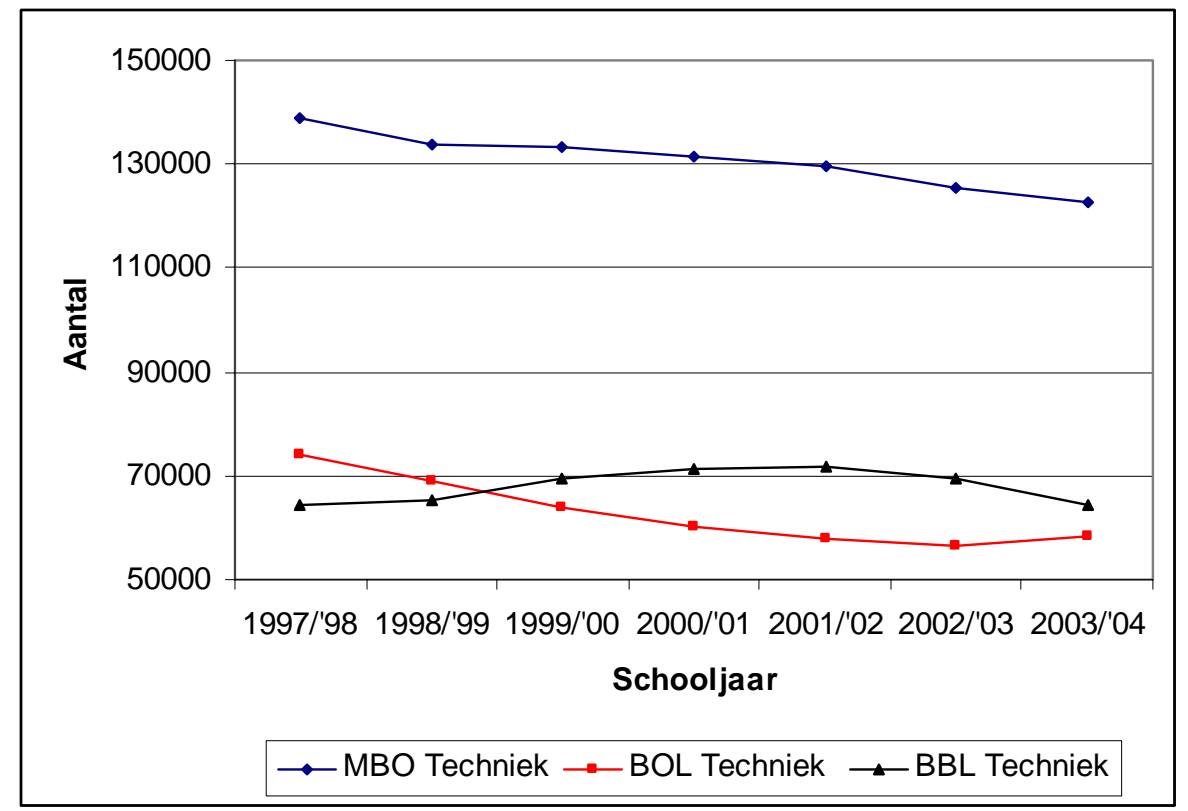

Bron: ROA/CBS

\subsection{Deelname aan MBO techniek in het Technogebied}

In deze paragraaf staat de deelname aan technisch middelbaar beroepsonderwijs in het Technogebied Zuidoost-Nederland centraal. Dit gebied omvat de Corop-gebieden Noordoost-Noord-Brabant, Zuidoost-Noord-Brabant, Noord-Limburg en MiddenLimburg. Aan het einde van deze paragraaf wordt tevens ingegaan op de grensoverschrijdende deelname aan het technisch onderwijs in Vlaanderen door Nederlandse leerlingen.

Zoals eerder opgemerkt is het aantal jongeren in de regio een factor die de ontwikkeling van het aantal MBO-leerlingen kan verklaren. In figuur 2.8 is daarom voor het Technogebied het aantal jongeren in de leeftijd van 15 tot 19 jaar en van 20 tot 24 jaar weergegeven, analoog aan figuur 2.6 voor Nederland als geheel. Het verloop van het aantal jongeren is iets grilliger in het Technogebied dan in Nederland als totaal. In grote lijnen is er echter hetzelfde patroon te zien: het aantal jongeren in de leeftijdsklasse van 20-24 jaar daalt vrij sterk tot 2000, en lijkt gedurende de laatste paar jaren te stabiliseren; het aantal jongeren in de leeftijdsklasse van 15-19 jaar daalde tot 1995, en is na het 2000 duidelijk aan het stijgen. In 1998 zijn er in het Technogebied evenveel jongeren van 15 tot 19 jaar als jongeren van 20 tot 24 jaar. Daarna is de eerste groep groter dan de tweede. Voor Nederland als geheel wordt dit punt pas in 2004 bereikt (zie figuur 2.6). Omdat het MBO voornamelijk put uit de groep van 15-19 jarigen, is wat dat betreft de situatie voor het middelbaar beroeps- 
onderwijs in het Technogebied iets rooskleuriger dan voor het middelbaar beroepsonderwijs elders in Nederland.

Figuur 2.8

Ontwikkeling van het aantal 15-24 jarigen in het Technogebied, 1990-2004

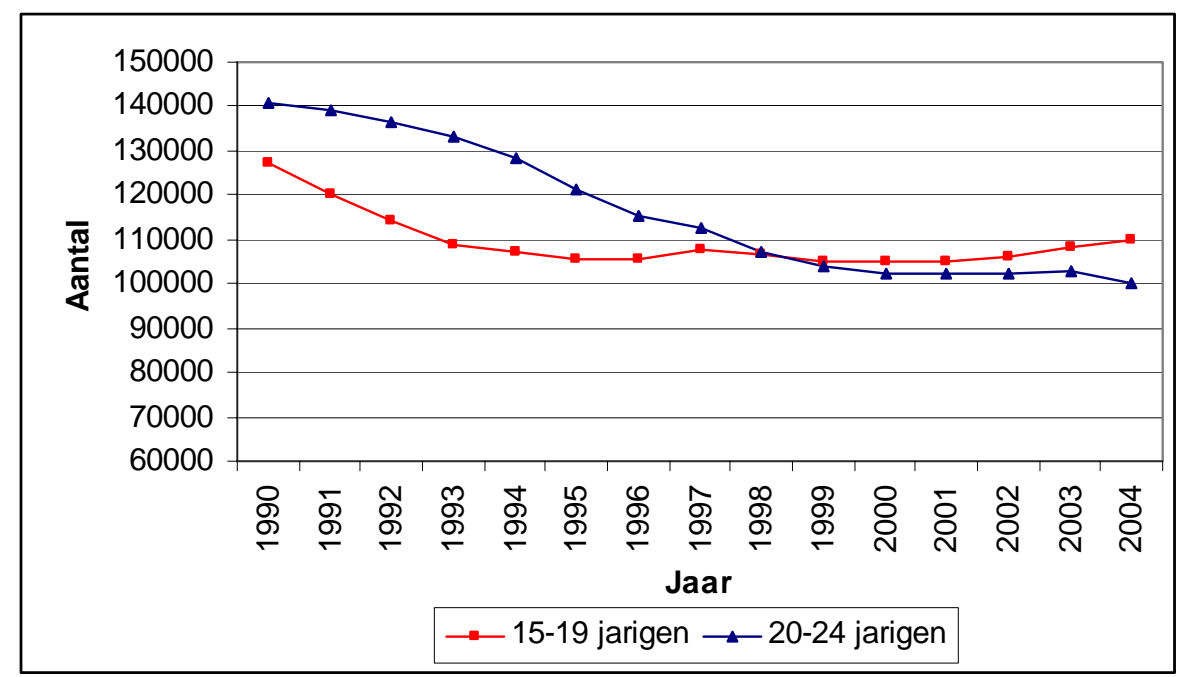

Bron: ROA/CBS

In figuur 2.9 is het totale aantal leerlingen van het MBO in het Technogebied weergegeven. We zien na een gestage stijging van het totaal aantal MBO-leerlingen een stabilisatie, die echter in het laatste jaar omslaat naar een lichte daling. Evenals bij de stijging op landelijk niveau, zou ook hier de invoering van het VMBO een oorzaak van de stijgende trend kunnen zijn. De afname van het totaal aantal leerlingen in het laatste schooljaar is moeilijk te verklaren. Het zou bijvoorbeeld kunnen betekenen dat meer leerlingen na het HAVO een HBO-opleiding in plaats van een MBO-opleiding zijn gaan volgen.

In figuur 2.9 wordt tevens het verloop van het aantal MBO-leerlingen met een technische opleiding in het Technogebied weergegeven. Hier vormt het regionale beeld een goede reflectie van het nationale beeld. Ook in het Technogebied daalt het aantal MBO-leerlingen in technische opleidingen, waarbij het dieptepunt nog niet in zicht lijkt. De daling heeft minder met demografische factoren te maken, want het aantal potentiële leerlingen (met name jongeren tussen 15 en 19 jaar) stijgt gedurende de laatste jaren, evenals het totale aantal MBO-leerlingen in het Technogebied (met uitzondering van het laatste jaar). De daling zou nog groter zijn uitgevallen als de bevolking en dus ook de groep potentiële leerlingen in het Technogebied was afgenomen. 
Figuur 2.9

Totaal aantal leerlingen in alle MBO-opleidingen en technische MBO-opleidingen in het Technogebied, 1997/'98-2003/'04

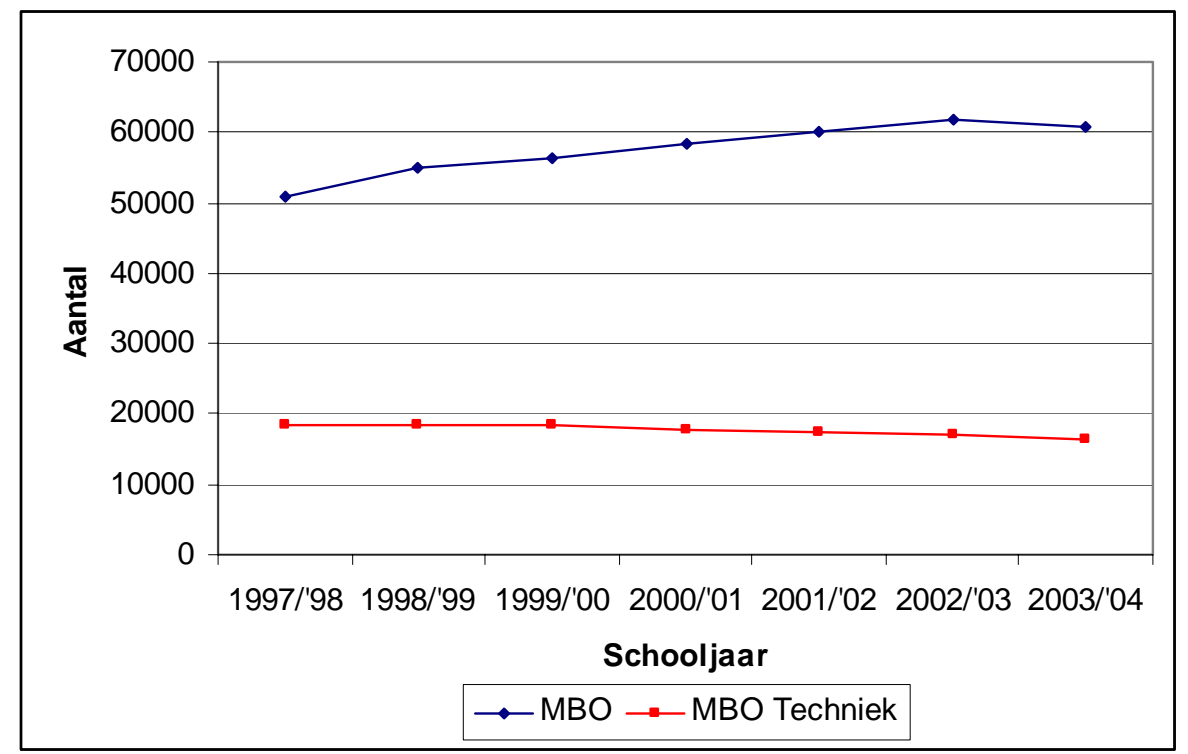

Bron: ROA/CBS

Figuur 2.10

Totaal aantal leerlingen in technische MBO-opleidingen in het Technogebied, uitgesplitst naar BOL en BBL, 1997/'98-2003/'04

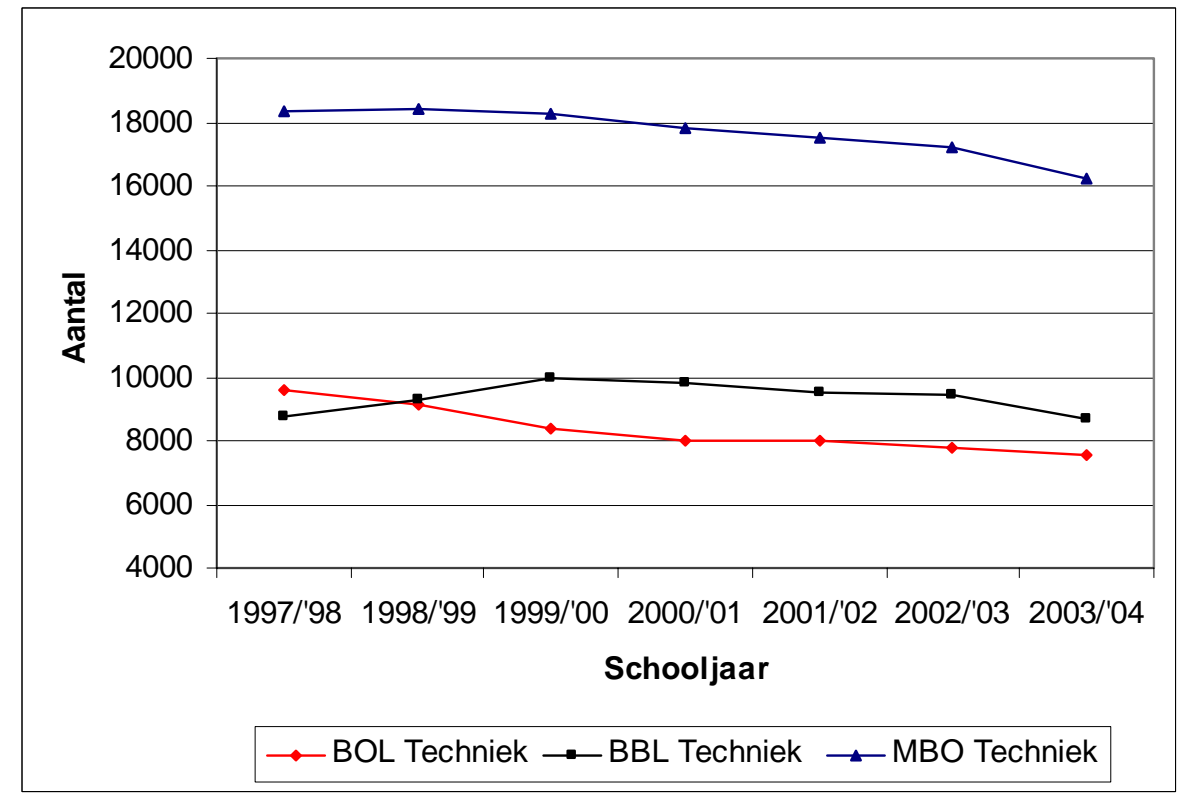

Bron: ROA/CBS 
In figuur 2.10 wordt het aantal leerlingen in MBO techniek verder uitgesplitst naar leerweg. De figuur laat zien dat het aantal BOL-leerlingen techniek tussen 1997 en 2004 voortdurend is gedaald. De sector techniek heeft vanaf het schooljaar 1999/2000 meer BBL- dan BOL-leerlingen. Na dat schooljaar zet echter ook de daling in van het aantal leerlingen techniek in het BBL. In tegenstelling tot de landelijke ontwikkeling (zie figuur 2.7), wordt de daling van het aantal BBL-leerlingen techniek in het Technogebied niet deels gecompenseerd door een stijging van het aantal BOL-leerlingen techniek.

Figuur 2.11 geeft een indicatie van het aandeel leerlingen dat een technische MBOopleiding volgt. Dit aandeel is dus afhankelijk van zowel het totaal aantal MBOleerlingen als het aantal MBO-leerlingen dat voor een technische MBO-opleiding kiest. In de figuur zien we een dalende trend vanaf 1997/'98 tot heden. Voor het Technogebied daalt het aandeel techniek van 36\% naar 27\%, voor Nederland van $30 \%$ naar $26 \%$. Het percentage leerlingen in technische opleidingen in Nederland is met 4\%-punt afgenomen sinds het schooljaar 1997/'98. Ook in de jaren voor $1997 /$ '98 was het aandeel techniek al aan het dalen. In het Technogebied is eveneens een dalend verloop van het aandeel leerlingen techniek te zien. $\mathrm{Er}$ is echter een duidelijk verschil, namelijk dat de daling in het Technogebied veel groter is dan voor Nederland als geheel: ruim 9\%-punt. Het aandeel van de sector techniek in het Technogebied is in het laatste jaar nog slechts 1\%-punt hoger dan in Nederland. Dat betekent dat het Technogebied zich wat betreft het aandeel van leerlingen dat een technische opleiding op het MBO volgt, beweegt in de richting van het landelijke gemiddelde (i.e. convergentie).

Figuur 2.11

Percentage leerlingen technische MBO-opleidingen in Nederland (NL) en in het Technogebied (TG), 1997/'98-2003/'04

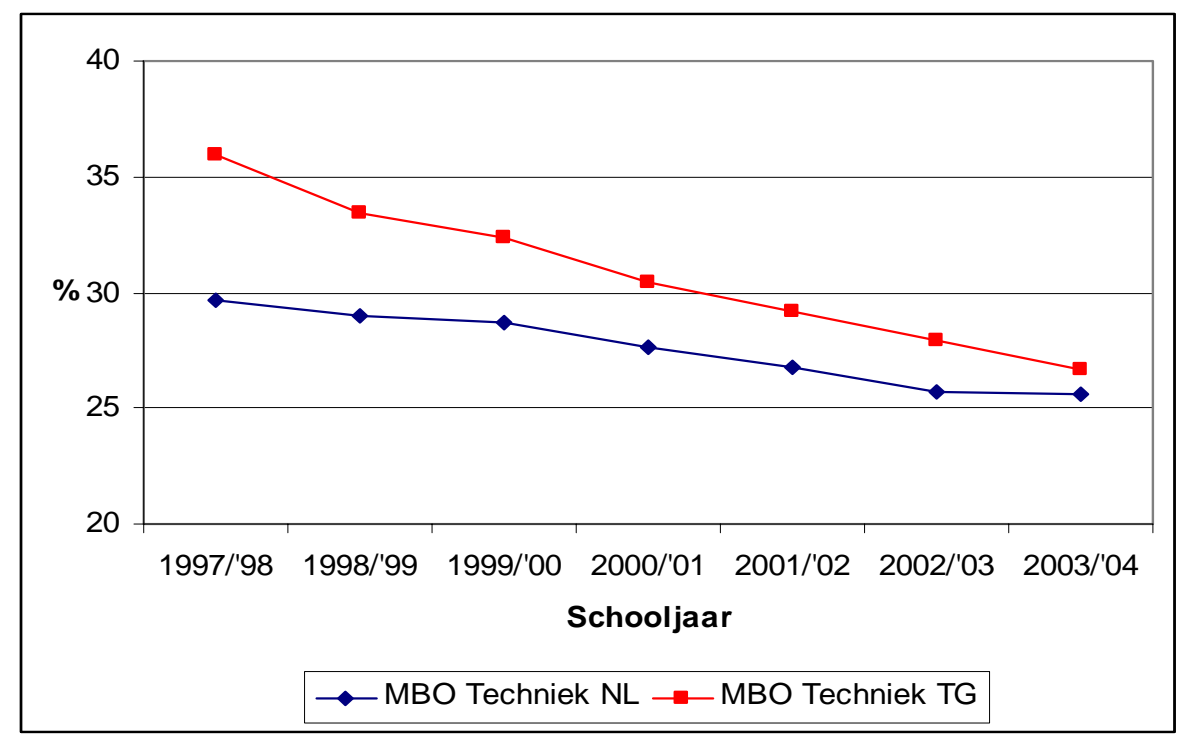

Bron: ROA/CBS 


\subsection{Deelname aan techniekonderwijs in Maaseik}

Van belang voor de ontwikkeling van het leerlingenaantal in Nederland zou verder het grensverkeer tussen Nederland en België kunnen zijn, in het bijzonder de Nederlandse leerlingen die in Vlaanderen (techniek)onderwijs volgen. ${ }^{11} \mathrm{Er}$ zijn drie Vlaamse gemeentes in het grensgebied met Nederland waar meer dan duizend Nederlandse leerlingen in het Vlaamse beroepsonderwijs staan ingeschreven (gegevens van schooljaar 2002/'03). Dit zijn Antwerpen (1.466), Arendonk (1.252) en Maaseik (1.799). Voor dit onderzoek zijn alleen de leerlingen uit Maaseik relevant, aangezien de andere twee Vlaamse gemeentes niet gunstig liggen voor leerlingen die in één van de vier Corop-gebieden van het Technogebied wonen.

Van de 1.799 Nederlandse leerlingen in Maaseik zijn er 1.501 grensoverschrijdend. Ruim 92\% (1.385) daarvan staat ingeschreven bij instellingen voor secundair onderwijs. Het betreft hier voor een groot deel het Technische Secundair Onderwijs (TSO) of het verwante maar meer praktisch gerichte BeroepsSecundair Onderwijs (BSO). Van belang is verder dat de scholen in het secundair onderwijs in Vlaanderen zowel het Voorbereidend Middelbaar BeroepsOnderwijs (VMBO) als het Middelbaar BeroepsOnderwijs (MBO) in Nederland omvatten. Het gaat in totaal om 655 Nederlandse leerlingen (in Nederland woonachtig) in het TSO en BSO in Maaseik. Een groot deel van de Nederlandse leerlingen in Maaseik volgt een technische beroepsopleiding bij het Technisch Instituut Sint-Jansberg, zowel in het speciaal onderwijs (Buitengewoon Secundair Onderwijs, BuSO) als in het gewoon secundair onderwijs (TSO en BSO). Deze laatste groep van leerlingen volgt voornamelijk lessen in de richtingen Elektrotechniek, Houtbewerking en Metaal. Vrijwel alle leerlingen wonen in het Technogebied of in Zuid-Limburg.

Uit aanvullende informatie van het Technische Instituut Sint-Jansberg blijkt dat het merendeel van de Nederlandse leerlingen op deze school begint vlak na het basisonderwijs, dat deze leerlingen voor het overgrote deel in Nederland volgen. lets minder dan 800 Nederlandse leerlingen (woonachtig in Nederland of Vlaanderen) volgen les aan het TI Sint-Jansberg; in de school voor buitengewoon onderwijs zijn er dat nog eens een kleine 200. Ook deze leerlingen stromen meestal in na het basisonderwijs in Nederland. Er zijn slechts ongeveer 220 in Nederland woonachtige Nederlandse leerlingen die ingestroomd zijn vanuit het VMBO in het TSO of BSO van het Technisch Instituut. Slechts ca. 40 van deze leerlingen hebben het VMBO succesvol afgesloten, onder wie 12 nieuwe leerlingen. Het overgrote deel van de Nederlandse leerlingen die aan het Technisch Instituut instromen en in Nederland woonachtig zijn, stroomt in nadat ze één of twee jaren VMBO achter de rug hebben.

Over het algemeen kan gesteld worden dat veruit het grootste deel van de Nederlandse leerlingen (al dan niet woonachtig in Nederland) al vroegtijdig in het Vlaamse onderwijs instroomt. Het gaat daarbij om Nederlandse leerlingen die het

11. De hier weergegeven informatie over Nederlandse leerlingen in België is ontleend aan Cornielje (2004), die zich onder meer baseert op gegevensbronnen van de Nederlandse en Vlaamse ministeries van onderwijs. Het grensverkeer van Vlaamse leerlingen naar Nederland is overigens gering. 
Vlaamse basisonderwijs volgen, of die meteen na het afsluiten van het Nederlandse basisonderwijs besluiten om verder te leren in het Vlaamse secundair onderwijs, of die zonder diploma vanuit het VMBO in het (speciaal) secundair onderwijs in Vlaanderen instromen. In veruit de meeste gevallen is er dus geen sprake van een keuze door gediplomeerde VMBO'ers tussen Vlaams secundair onderwijs en Nederlands middelbaar beroepsonderwijs, omdat de meeste Nederlandse leerlingen (of hun ouders) al op jongere leeftijd voor het Vlaamse onderwijs hebben gekozen. Het opleidingenaanbod in Maaseik speelt derhalve geen rol bij de keuze voor techniek door VMBO'ers, of bij de ontwikkeling van de deelname aan techniek in het Nederlandse middelbaar beroepsonderwijs.

\subsection{Leerlingen per deelsector techniek in het Technogebied}

De sector techniek wordt door het CBS in de Standaard OnderwijsIndeling (SOI, zie Bijlage 2) onderverdeeld in acht verschillende deelsectoren. Figuur 2.12 geeft de geïndexeerde ontwikkeling van het aantal leerlingen per deelsector in het Technogebied weer. Bij deze ontwikkeling van het aantal leerlingen techniek valt een aantal deelsectoren op.

Figuur 2.12

Ontwikkeling van het aantal leerlingen per deelsector techniek in het Technogebied, van 1997/'98 (=100) tot 2003/'04

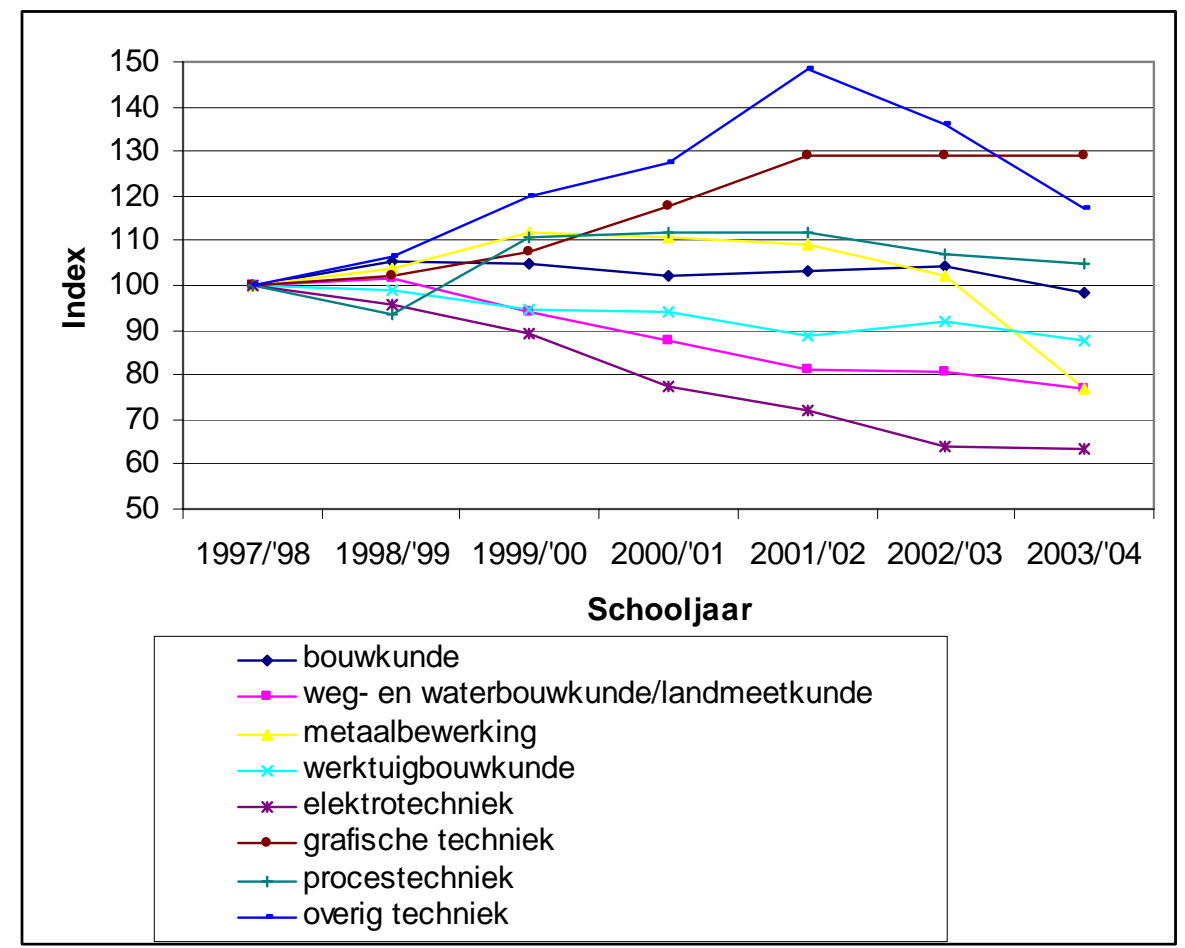

Bron: ROA/CBS 
Allereerst blijkt dat het aantal leerlingen niet voor alle deelsectoren in de techniek afneemt, ondanks de daling van het totale aantal MBO-leerlingen techniek. Het leerlingenaantal in grafische techniek is in de afgelopen zeven jaar met $30 \%$ gestegen, en het aantal leerlingen van de overige technische opleidingen (niet bij de zeven andere deelsectoren behorend) met $17 \%$ is gestegen. Verder ligt het aantal leerlingen van procestechniek 1\% hoger dan zeven jaar geleden. De overige vijf deelsectoren zijn in verschillende mate kleiner geworden wat betreft de leerlingaantallen. Bouwkunde bijvoorbeeld is slechts met $2 \%$ gekrompen, terwijl het aantal leerlingen van metaalbewerking en ook van water- en wegbouwkunde/landmeetkunde met $21 \%$ is afgenomen. Bij metaalbewerking komt dit vrijwel volledig door de zeer sterke daling in het laatste jaar. Het aantal leerlingen elektrotechniek is zelfs met meer dan een derde (36\%) afgenomen in de afgelopen zeven jaar.

Tot slot geeft figuur 2.13 inzicht in het aandeel van de verschillende richtingen in de sector techniek. De grootste richtingen zijn bouwkunde en werktuigbouwkunde. Het aantal leerlingen van bouwkunde daalt tussen 1997/'98 en 2003/'04, terwijl het aandeel binnen techniek stijgt van $27 \%$ naar $31 \%$. Ondanks een afname van $12 \%$ in leerlingenaantal is het aandeel van werktuigbouwkunde onveranderd op $25 \%$ van het totaal aantal leerlingen in de techniek. Het aandeel elektrotechniek binnen de sector techniek daalt aanzienlijk, namelijk van bijna $22 \%$ naar $15 \%$. Overig techniek stijgt weliswaar sterk tussen 1997/'98 en 2003/'04, maar dit heeft slechts een geringe verandering van het aandeel in de hele sector techniek tot gevolg (van 1,4\% naar $1,8 \%)$.

Figuur 2.13

Aandeel deelsectoren van het totaal aantal leerlingen techniek in het Technogebied, 2003/'04

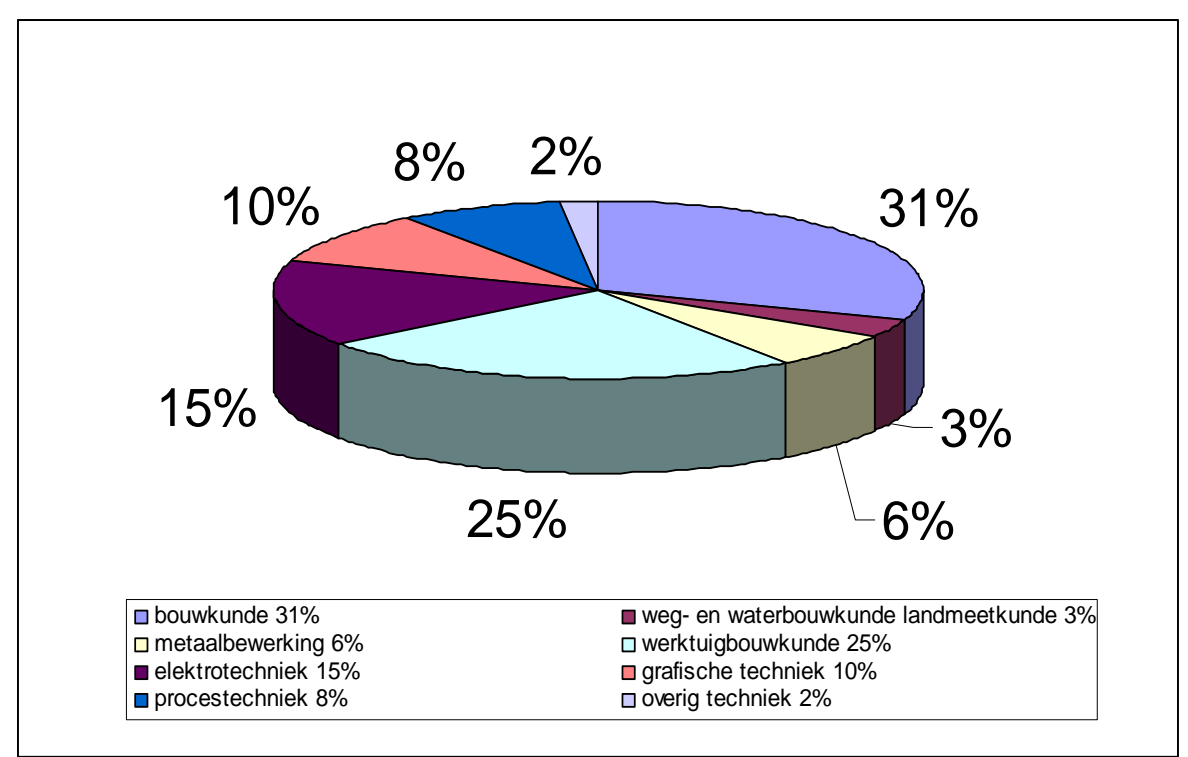

Bron: ROA/CBS 


\subsection{Conclusies}

Aanbod technische opleidingen in Limburgse deel van Technogebied kleiner dan in Brabantse deel

Het valt op dat in Zuidoost-Noord-Brabant de locaties met technische opleidingen in en rondom Eindhoven geconcentreerd zijn. Daarentegen zijn de opleidingslocaties in Noordoost-Noord-Brabant redelijk goed gespreid. Toch worden de meeste opleidingen in Noord-Brabant in slechts enkele gemeentes aangeboden, namelijk Eindhoven, 's Hertogenbosch, Helmond, Oss en Veghel. In Rosmalen (gemeente 's-Hertogenbosch), Boxtel, Nuenen, Mierlo en Veldhoven wordt een beperkt aantal technische opleidingen aangeboden.

In het Limburgse deel van het Technogebied is de dichtheid van de locaties waar technische opleidingen worden aangeboden kleiner dan in het Noord-Brabantse deel. In Roermond en Venlo is er een breed opleidingenaanbod. In Weert, Horst en Venray is het opleidingenaanbod zeer beperkt.

De jongeren met interesse voor techniek en woonachtig in de perifere gebieden van het Technogebied Zuidoost-Nederland kunnen kiezen voor de ROC's in in Tilburg, Arnhem, Nijmegen, Maastricht, Heerlen en Tiel, of een nevenvestiging in SittardGeleen en Geldermalsen. Een andere mogelijkheid voor deze jongeren is om uit te wijken naar België, bijvoorbeeld naar het Technisch Instituut Sint-Jansberg in Maaseik. In veruit de meeste gevallen lijkt er echter geen sprake te zijn van een keuze door gediplomeerde VMBO'ers tussen Vlaams secundair onderwijs en Nederlands middelbaar beroepsonderwijs, omdat de meeste Nederlandse leerlingen (of hun ouders) al op jongere leeftijd voor het Vlaamse onderwijs hebben gekozen. Het opleidingenaanbod in Maaseik speelt derhalve geen rol bij de keuze voor techniek door VMBO'ers, of bij de ontwikkeling van de deelname aan techniek in het Nederlandse middelbaar beroepsonderwijs.

Deelname aan techniek hangt af van demografie, keuze voor MBO en populariteit techniek

Naast de spreiding van opleidingslocaties kunnen drie andere factoren worden genoemd die van invloed zijn op de ontwikkeling van het aantal leerlingen dat voor een technische opleiding kiest. ${ }^{12}$ Wat betreft de leerlingenaantallen in het middelbaar technisch beroepsonderwijs hebben we voornamelijk gekeken naar de periode van

12. Het is duidelijk dat op individueel niveau veel meer factoren een rol spelen bij de opleidingskeuze, zoals bijv. geslacht, opleidingsniveau/richting ouders, sociaal milieu, etniciteit, gezinssituatie, etc. Deze factoren zijn vaak echter nauwelijks van belang op regionaal niveau. Zo is het geslacht sterk bepalend voor de opleidingskeuze, maar kan de verdeling van jongens en meisjes in de bevolking niet een verandering in de opleidingskeuze verklaren omdat deze verdeling bijna niet wijzigt. Daarentegen zou de toename van het aantal allochtonen wel een verklaring kunnen bieden voor de afnemende belangstelling voor techniek. Allochtonen kiezen immers minder snel voor een technische opleiding (zie ook hoofdstuk 6). In de voor dit hoofdstuk gebruikte databestanden over leerlingen wordt echter geen onderscheid naar etniciteit gemaakt. 
de schooljaren 1997/'98 tot 2003/'04. De eerste factor is het aantal jongeren in de leeftijdsklasse van 15-24 jaar. Hoe meer jongeren er zijn, hoe groter het potentieel aan leerlingen dat voor techniek kan kiezen. Het aantal jongeren is na het jaar 2000 weer aan het toenemen, vooral in de leeftijdsklasse 15-19 jaar. Deze constatering geldt voor zowel Nederland als het Technogebied.

Ten tweede is het aantal jongeren dat voor middelbaar beroepsonderwijs kiest van belang. Ook hiervoor geldt dat een toename van het aantal leerlingen in het MBO, een groter potentieel genereert aan leerlingen dat voor het middelbaar technisch beroepsonderwijs kan kiezen. Het totale aantal MBO-leerlingen is gedurende de periode die we onderzocht hebben vrijwel voortdurend toegenomen. Ook hierin verschillen Nederland en het Technogebied nauwelijks. De toename van het totaal aantal leerlingen in het MBO kan voor een groot deel toegeschreven worden aan een stijging van het aantal BBL-leerlingen, welke met name gerelateerd is aan de conjunctuur. Een aanwijzing voor de relatie met de conjunctuur geeft ook de daling van het aantal BBL-leerlingen in het schooljaar 2003/'04.

Ten derde speelt de populariteit van techniekopleidingen onder jongeren die voor het MBO kiezen een rol. Hoe groter deze populariteit is, hoe groter het aandeel jongeren dat een technische opleiding volgt in het middelbaar beroepsonderwijs. Het blijkt dat dit aandeel voor zowel Nederland als het Technogebied aanzienlijk is gedaald in de onderzochte periode, namelijk met 4\%-punt in Nederland en 9\%-punt in het Technogebied. Het aandeel van de sector techniek is in het Technogebied nog slechts $1 \%$-punt hoger dan in Nederland.

\section{Daling deelname aan BBL en elektrotechniek in Technogebied}

Voorts zijn er nog twee ontwikkelingen van belang ten aanzien van deelname aan één van de twee leerwegen en de verschillende opleidingsrichtingen binnen techniek. Wat betreft de leerwegen valt het op dat de beroepsbegeleidende leerweg (BBL) binnen de sector techniek vanaf het schooljaar 1999/2000 meer leerlingen heeft dan de beroepsopleidende leerweg (BOL) in het Technogebied. $\mathrm{Na}$ dat schooljaar zet echter onder invloed van de neergaande conjunctuur ook de daling in van het aantal leerlingen techniek in de BBL. In tegenstelling tot de landelijke ontwikkeling, wordt de daling van het aantal BBL-leerlingen techniek niet deels gecompenseerd door een stijging van het aantal BOL-leerlingen techniek.

Wat betreft de verdeling van de leerlingen over de verschillende opleidingsrichtingen binnen techniek, valt op dat vooral elektrotechniek flink aan belangstelling heeft ingeboet in het Technogebied. ${ }^{13}$ Voor vrijwel alle technische richtingen in het Technogebied is het aantal leerlingen gedaald, met uitzondering van grafische techniek, procestechniek en techniek overig.

13. In een onderzoek van Cinop (2002) wordt aangegeven dat een groot deel van leerlingen die voorheen voor technische MBO-opleidingen kozen, de laatste jaren voor een ICTopleiding kiezen. Deels zijn ICT-opleidingen echter verwant aan elektrotechniek en worden ze in dit rapport bij elektrotechniek geteld (zie Bijlagen 1 en 2). Voor een ander deel worden deze leerlingen in dit rapport ingedeeld bij een economische richting. 
Daling van populariteit techniek is groter dan landelijk, maar niet toe te schrijven aan inkrimping aanbod van technische opleidingen

Geconcludeerd kan worden dat de dalende trend in de deelname aan het middelbaar technisch beroepsonderwijs in het Technogebied voor een belangrijk deel overeenkomt met de landelijke ontwikkeling. Van belang is echter dat deze dalende trend sterker is in het Technogebied dan in de rest van Nederland. In hoofdstuk 3 zal bekeken worden of deze ontwikkelingen ook waar te nemen zijn binnen het VMBO en het HBO.

Het is op basis van de analyses in dit hoofdstuk niet mogelijk om een goede verklaring te geven voor de dalende populariteit van technische opleidingen. Hoewel er veel fusies plaats hebben gevonden tussen scholen in het middelbaar beroepsonderwijs, en er ook enkele opleidingslocaties in het Technogebied zijn (of worden) gesloten waar technische opleidingen werden aangeboden (bijv. Laboratoriumtechniek in Venlo door Gilde Opleidingen), hebben wij geen directe aanwijzingen dat dit op een zodanig grote schaal is gebeurd dat daardoor het aantal leerlingen dat voor een technische opleiding kiest is afgenomen. Men zou evenzeer kunnen betogen dat deze opleidingslocaties zijn gesloten omdat de belangstelling voor deze opleidingen sterk was afgenomen.

De daling in de belangstelling voor techniek is een verschijnsel dat al veel langer speelt en zich niet beperkt tot de periode waarin locaties met technische opleidingen zijn gesloten. Bovendien dient men rekening te houden met andere factoren die de daling in de deelname aan technische opleidingen kunnen verklaren, zoals een toename in de belangstelling voor ICT die met name de deelname aan elektrotechniek zou kunnen treffen (vanwege de verwantschap tussen opleidingen binnen ICT en electrotechniek, zie Cinop, 2002), en de neergaande conjunctuur waardoor er minder BPV-plaatsen voor BBL-leerlingen beschikbaar komen. 



\section{Doorstroom binnen de beroepskolom en arbeidsmarktintrede}

Veel leerlingen van het MBO zijn afkomstig uit het Voorbereidend Middelbaar BeroepsOnderwijs (VMBO). Gezien het grote belang van het VMBO voor het MBO, zal in paragraaf 3.1 worden nagegaan hoe het aantal VMBO-gediplomeerden zich gedurende de afgelopen jaren heeft ontwikkeld. Er wordt gekeken naar het totaal van VMBO-gediplomeerden en naar het aantal VMBO-gediplomeerden in de sector techniek. Daarnaast wordt er gekeken naar de instroom vanuit het VMBO in het MBO. De doorstroom binnen de beroepskolom van het technisch onderwijs wordt vergeleken met het totale beroepsonderwijs. Hierbij wordt tevens Nederland als geheel vergeleken met het Technogebied.

In paragraaf 3.2 wordt verder ingegaan op de aansluiting tussen onderwijs en arbeidsmarkt van gediplomeerde schoolverlaters van het $\mathrm{MBO}$, waarbij tevens gedifferentieerd wordt naar techniek voor Nederland als geheel en voor het Technogebied. Naast de afname van het aantal MBO-leerlingen in de technische richting, zoals geconstateerd in het vorige hoofdstuk, speelt ook de vraag naar middelbaar opgeleide technici op de arbeidsmarkt een belangrijke rol bij de aansluiting tussen onderwijs en arbeidsmarkt. Regionale verschillen in vraag en aanbod van arbeid zorgen voor werkloosheid, dan wel vacatures op de lokale arbeidsmarkt. De discrepanties op de arbeidsmarkt kunnen verminderen als de geografische mobiliteit van schoolverlaters groter wordt. Verder kan een slechte aansluiting tussen onderwijs en arbeidsmarkt van schoolverlaters van het MBO leiden tot verdringing van lager opgeleiden en onderbenutting van de middelbaar opgeleiden. Bovendien kan een deel van de technisch opgeleide schoolverlaters verloren gaan aan beroependomeinen buiten de techniek. Indicatoren hiervoor worden, naast andere indicatoren over de arbeidsmarktintrede, zoals deeltijdwerk en aanstellingsduur, in paragraaf 3.2 besproken. Op deze wijze kan worden nagegaan hoe de aansluiting tussen onderwijs en arbeidsmarkt van schoolverlaters met een technische opleidingsachtergrond in het Technogebied zich verhoudt tot die van schoolverlaters buiten het Technogebied en in andere richtingen.

In paragraaf 3.3 wordt gekeken naar de doorstroom vanuit het MBO naar het HBO, en de ontwikkeling van het aantal HBO-leerlingen. Tot slot wordt in paragraaf 3.4 aandacht geschonken aan de arbeidsmarktintrede van HBO'ers, wederom gedifferentieerd naar richting (techniek versus niet-techniek) en gebied (Nederland en Technogebied) voor de verschillende hierboven genoemde indicatoren (werkloosheid, onderbenutting, etc.). Voor de analyse van de arbeidsmarktintrede en de doorstroom binnen het onderwijs zijn acht uitstroomcohorten van gediplomeerden uit de RUBS-enquête en de HBO-monitor samengenomen. ${ }^{14}$ De enquêtes hebben

14. De gegevens van de RUBS-enquête en de HBO-monitor worden samen met de gegevens van de WO-monitor geïntegreerd in het SchoolverlatersInformatieSysteem (SIS). 
betrekking op de meetjaren 1996 tot en met 2003. In paragraaf 3.5 volgen de conclusies.

\subsection{Uitstroom van VMBO}

In figuur 3.1 is het totaal aantal VMBO- gediplomeerden in Nederland weergegeven, als ook het aantal gediplomeerden uit de sector techniek.

Figuur 3.1

Aantal gediplomeerden van VMBO-opleidingen in Nederland (NL), totaal en techniek, 1997/'982002/'03

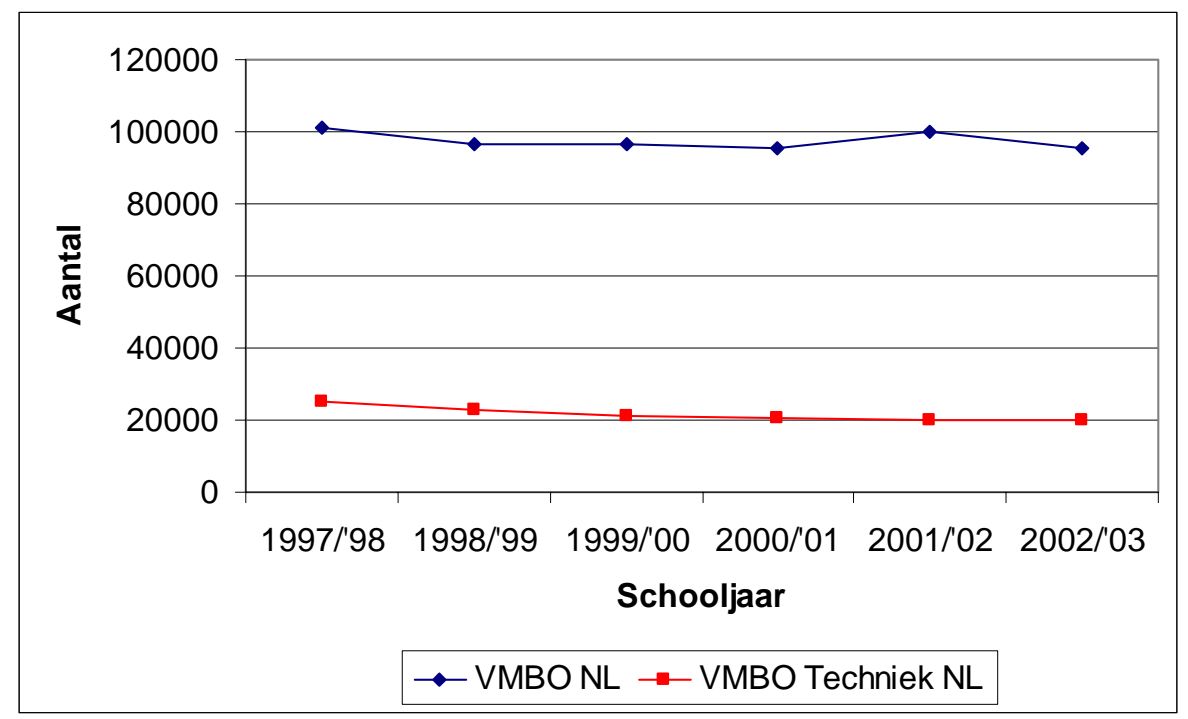

Bron: ROA/CBS

Het blijkt dat het totaal aantal VMBO-gediplomeerden in de weergegeven periode nogal fluctueert. In het laatste jaar ligt het aantal gediplomeerden ongeveer 5.500 lager dan in het eerste jaar. Bij de gediplomeerden uit de sector techniek is er een ander verloop zichtbaar. Tussen 1997/'98 en 2002/'03 daalt het aantal gediplomeerden aanvankelijk, waarna het stabiliseert in 2001/'02. In het laatste jaar van waarneming stijgt het aantal VMBO-gediplomeerden, zij het slechts met enkele tientallen.

In het Technogebied is een vergelijkbaar beeld te zien wat betreft het aantal VMBOgediplomeerden. ${ }^{15}$ In figuur 3.2 zijn dezelfde gegevens als hierboven weergegeven, maar nu met betrekking tot het Technogebied. De vergelijking tussen Nederland en het Technogebied laat weinig verschil zien wat betreft het verloop van het aantal

15. Zie Bijlage 3 voor een overzicht van de VMBO-instellingen met en zonder een sector techniek in het Technogebied Zuidoost-Nederland. Het blijkt dat de concentratie van opleidingslocaties in het VMBO minder sterk is doorgevoerd dan in het MBO. Alleen in het Limburgse deel van het Technogebied zijn er VMBO-scholen waar geen technische opleidingen worden aangeboden. Voor deze scholen bestaat echter een alternatief in dezelfde of in een aangrenzende gemeente. 
gediplomeerden in totaal en techniek. Ook in het Technogebied daalt het totaal aantal gediplomeerden met een fluctuerend patroon. Daarnaast is ook de trend van afname tot stabilisatie bij de gediplomeerden techniek zichtbaar.

Figuur 3.2

Aantal gediplomeerden van VMBO-opleidingen in het Technogebied (TG), totaal en techniek, 1997/'98-2002/'03

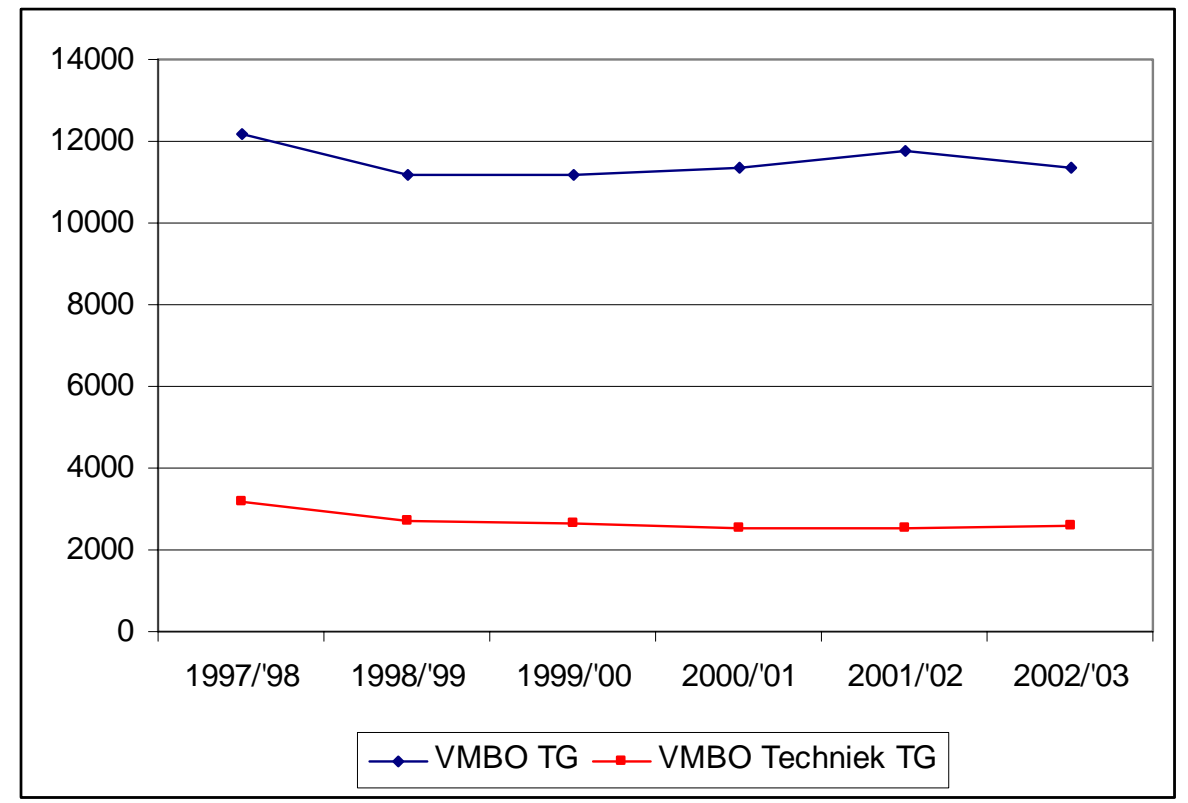

Bron: ROA/CBS

In figuur 3.3 is het aandeel techniek in het totaal aantal VMBO-gediplomeerden voor zowel Nederland als het Technogebied afgebeeld. Het aandeel techniek in het Technogebied is ongeveer 1,5\%-punt groter dan in Nederland. In 2002/'03 is het aandeel techniek in het Technogebied 22,7\%. De figuur laat verder zien dat er tussen 1997/'98 en 2001/'02 in Nederland en het Technogebied sprake was van een gestage afname van het aandeel techniek. Daarna steeg het aandeel weer met 1 à 2 \%-punt. Per saldo is er sprake van een daling van ongeveer 3,5\%-punt over de gehele periode. Hierbij valt op te merken dat de stijging in het laatste schooljaar meer toe te schrijven is aan de afname van het totale aantal VMBO-gediplomeerden in andere sectoren dan techniek dan aan een stijging van het aantal VMBOgediplomeerden techniek.

Zowel in Nederland als in het Technogebied is het aantal VMBO-gediplomeerden afgenomen. Deze trend zal waarschijnlijk de komende jaren doorzetten, want ook de leerlingenaantallen nemen af. Leerlingen kiezen steeds vaker voor het HAVO in plaats van het VMBO als zij de capaciteiten hebben om door te stromen naar het HAVO (CBS, 2002). De afname van het aantal VMBO-leerlingen heeft als gevolg dat het Middelbaar BeroepsOnderwijs veel minder sterk zal groeien dan het Hoger BeroepsOnderwijs, en in mindere mate ook het Wetenschappelijk Onderwijs (CBS, 
2002). Dit heeft tot gevolg dat ook het aantal gediplomeerden in de technische sector van het VMBO en het MBO zal afnemen, zelfs als het aandeel van de leerlingen dat voor techniek kiest constant blijft.

\section{Figuur 3.3}

Percentage gediplomeerden techniek van het totaal aantal VMBO-gediplomeerden in Nederland (NL) en in het Technogebied (TG), 1997/'98-2002/'03

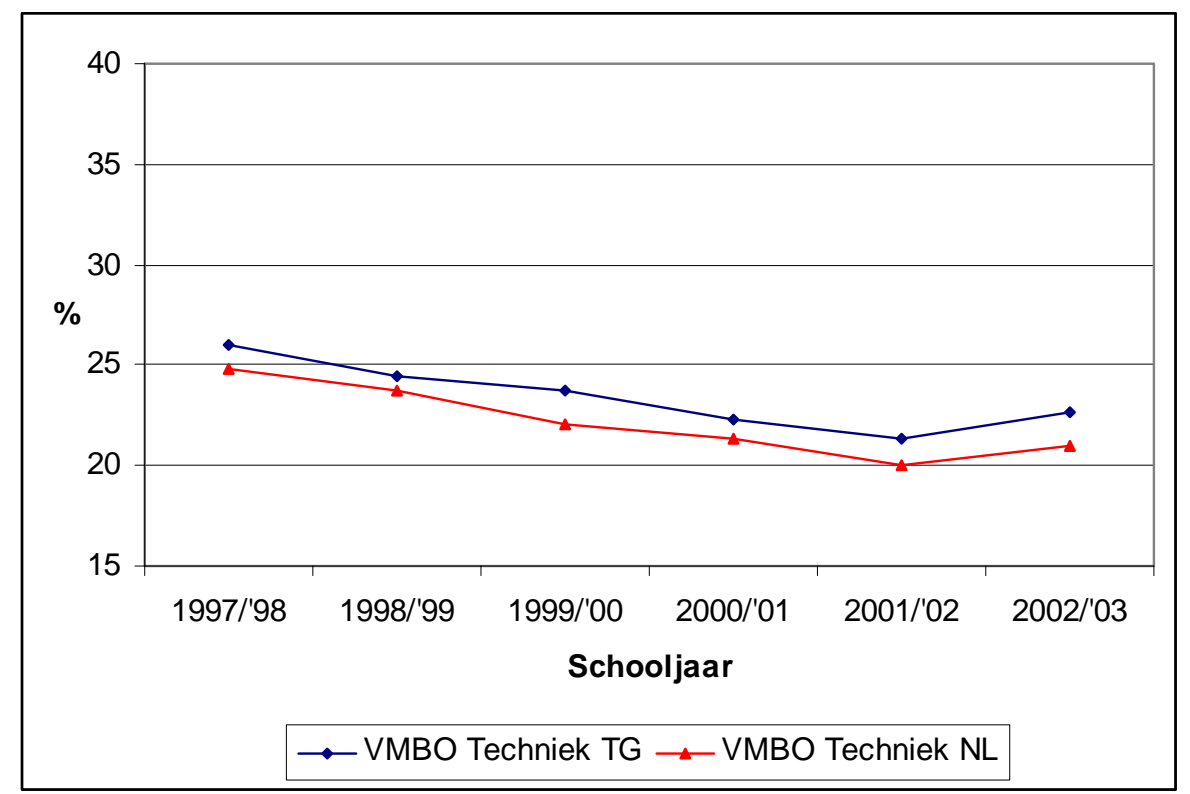

Bron: ROA/CBS

In Nederland stromen na het behalen van het VMBO-diploma jaarlijks ongeveer 19.000 VMBO-gediplomeerden (ongeveer 20\% van het totale aantal) niet of niet direct door naar vervolgonderwijs. Daarnaast stromen circa 11.000 VMBO-leerlingen uit zonder diploma. De jongeren die na het VMBO afzien van vervolgonderwijs lopen het risico op termijn onvoldoende inzetbaar te zijn op de arbeidsmarkt, waardoor er een relatief grote kans is op werkloosheid en inactiviteit. Zij beschikken niet over een zogenaamde startkwalificatie voor de arbeidsmarkt (minimaal MBO niveau 2, of hoger), hun opleiding is immers bedoeld als voorbereiding op het middelbaar beroepsonderwijs. Door middel van de versterking van de beroepskolom en het beleid ten aanzien van voortijdig schoolverlaters wordt beoogd dit potentieel voor het middelbaar beroepsonderwijs te behouden (OCW, 2003). In Tabel 3.1 zijn de vervolgopleidingen van VMBO-gediplomeerden die wel doorstromen in het vervolgonderwijs weergegeven.

Uit tabel 3.1 blijkt dat veruit het grootste deel van de VMBO'ers dat verder leert in het MBO terecht komt. Van alle VMBO-schoolverlaters in Nederland en het Technogebied gaat bijna 94\% verder leren in een BOL- of BBL-opleiding. Voor VMBOschoolverlaters techniek is dit aantal nog hoger, ongeveer 97\%. Dit komt voornamelijk door de slechte toegankelijkheid van het HAVO voor VMBO'ers die niet de theoretische leerweg gevolgd hebben. Ongeveer 40\% sluit het VMBO af met een 
diploma in de theoretische leerweg. BOL-opleidingen van niveau 3/4 zijn veruit het populairst bij schoolverlaters van het VMBO in Nederland en het Technogebied, vooral onder schoolverlaters van de zogenaamde kaderberoepsgerichte leerweg, de gemengde leerweg en de theoretische leerweg. ${ }^{16}$

Tabel 3.1

Vervolgopleidingen van VMBO-gediplomeerden, als percentage van het totaal aantal gediplomeerde VMBO-schoolverlaters dat doorleert, gemiddelde 1996-2003

\begin{tabular}{|c|c|c|c|c|}
\hline \multirow[t]{2}{*}{ Vervolgopleiding } & \multicolumn{2}{|c|}{ Nederland } & \multicolumn{2}{|c|}{ Technogebied } \\
\hline & totaal & techniek & totaal & techniek \\
\hline HAVO & 5 & 1 & 5 & 0 \\
\hline VBO & 1 & 2 & 1 & 3 \\
\hline BOL niveau $1 / 2$ & 15 & 16 & 16 & 15 \\
\hline BOL niveau $3 / 4$ & 62 & 37 & 64 & 38 \\
\hline BBL niveau $1 / 2$ & 10 & 31 & 7 & 30 \\
\hline BBL niveau $3 / 4$ & 8 & 14 & 6 & 14 \\
\hline Totaal & 100 & 100 & 100 & 100 \\
\hline
\end{tabular}

Bron: ROA/SIS

Schoolverlaters met een techniekdiploma op zak kiezen ongeveer drie keer zo vaak als gemiddeld voor een BBL-opleiding. Bovendien kiezen schoolverlaters van de richting techniek VMBO relatief vaak voor een BBL-opleiding op niveau 1/2. Dit zijn veelal schoolverlaters van de zogenaamde basisberoepsgerichte leerweg op het VMBO, de leerweg op het laagste niveau. Werkgevers geven vaak te kennen dat MBO-schoolverlaters van niveau 1/2 relatief slecht inzetbaar zijn, waardoor de arbeidsmarktpositie van deze schoolverlaters over het algemeen slechter is dan die van schoolverlaters van niveau 3/4 (zie bijv. Van Eijs, 2003).

Van groot belang voor de doorstroom binnen de beroepskolom is verder de richting van de vervolgopleidingen. Welk deel van de schoolverlaters van de sector techniek stroomt door naar een technische dan wel een niet-technische vervolgopleiding? Bij het VMBO is de keuze voor een sector vaak nog niet erg definitief. Uit het RUBSbestand 1996-2003 blijkt dat 25\% van alle gediplomeerde VMBO-schoolverlaters die doorleren aan een technische vervolgopleiding deelneemt. In het Technogebied is dit percentage iets hoger, namelijk 26\%.

In Nederland blijft $82 \%$ van de doorlerende VMBO-gediplomeerden met een technische opleiding binnen de technische sector op het $\mathrm{MBO}$, tegenover $84 \%$ in het Technogebied. In het Technogebied kiezen doorlerende VMBO-gediplomeerden van de sector techniek dus relatief vaak voor een vervolgopleiding binnen de sector techniek op het MBO. Uit een studie van het ITS (Van Kuijk en Wartenbergh-Cras, 2004) naar de doorstroom van VMBO'ers van het Raayland College in Venray, blijkt dat slechts $76 \%$ van de VMBO-gediplomeerden techniek doorstroomt naar een

16. Deze drie leerwegen op het VMBO geven toegang tot niveau 3 en 4 op het MBO. Via de theoretische leerweg is er bovendien toegang tot het HAVO. Naast deze drie leerwegen is er nog een vierde leerweg, de basisberoepsgerichte leerweg. Deze zeer praktijkgerichte leerweg geeft alleen toegang tot niveau 1 en 2. Zie voor meer informatie http://www. vmbo.nl/. 
technische MBO-opleiding in de regio. Verschillen in de steekproefkenmerken en de leerlingenpopulatie, maar ook uiteenlopende regiokenmerken en andere waarnemingsjaren kunnen debet zijn aan het verschil in uitkomsten. Voorlopige conclusie is dat ongeveer $80 \%$ van de doorlerende VMBO'ers met een diploma techniek binnen de sector techniek op het MBO verder leert, en niet verloren gaat aan andere sectoren of aan het HAVO/VWO. Binnen het Technogebied was dat percentage gemiddeld genomen over de afgelopen jaren iets hoger.

\subsection{Arbeidsmarktintrede na MBO}

Schoolverlaters van het MBO kiezen er na het behalen van hun diploma vaak voor om een baan te zoeken. Door verschillen tussen vraag en aanbod van arbeid in de regio kunnen zij enige tijd nodig hebben om een baan te vinden. Om werkloosheid te voorkomen hebben schoolverlaters verschillende mogelijkheden. Ze kunnen bijvoorbeeld langer doorstuderen, of een baan accepteren beneden hun opleidingsniveau. In dat laatste geval is er sprake van overscholing. Overscholing kan verdringing van lager opgeleiden tot gevolg hebben. WO'ers nemen arbeidsplaatsen van HBO'ers in, die op hun beurt weer moeten uitwijken naar banen op MBO-niveau. Zo kan het dus ook voorkomen dat MBO'ers op VMBO-niveau moeten gaan werken om niet werkloos te worden, en daarmee de lager geschoolde VMBO'ers verdringen. Uit onderzoek van Asselberghs et al. (1998) komen aanwijzingen naar voren die er op duiden dat het gemiddelde opleidingsniveau van de Nederlandse beroepsbevolking sterker gestegen is dan het niveau van de beschikbare banen. Dat zou er toe leiden dat steeds meer werkenden in Nederland beneden hun opleidingsniveau werkzaam zijn.

Een tweede mogelijkheid voor schoolverlaters om werkloosheid te omzeilen is het accepteren van een baan die niet, of in mindere mate, aansluit op de gevolgde studierichting. De schoolverlater is dan werkzaam buiten het eigen beroependomein. Deze twee alternatieven volgen uit een mismatch tussen vacatures en schoolverlaters binnen het geografisch gebied, waarin de schoolverlater naar een baan zoekt. In plaats van een baan te accepteren van een ander niveau of uit een andere richting kan het geografisch gebied waarbinnen gezocht wordt ook vergroot worden. Omdat verschillen tussen vraag en aanbod van arbeidskrachten heel lokaal kunnen zijn, is de kans op een baan op niveau en binnen de eigen richting groter naarmate het zoekgebied groter wordt. $\mathrm{Er}$ is dan sprake van een 'trade-off' tussen de aansluiting tussen opleiding en beroep en de bereidheid om te pendelen of te verhuizen.

Enerzijds kunnen schoolverlaters bij een overschot op de lokale arbeidsmarkt uitwijken naar een baan buiten eigen niveau of richting. Om dit te voorkomen kunnen ze gaan pendelen tussen woonplaats en werk of verhuizen naar de werklocatie. Dit is vooral van toepassing wanneer er een overschot bestaat aan bepaalde gediplomeerden. Anderzijds kunnen werkgevers bij tekorten op de arbeidsmarkt geschikte schoolverlaters van buiten hun directe omgeving proberen aan te trekken, bijvoorbeeld door het betalen van reiskosten, verhuiskosten, of zelfs huisvestiging. De mate waarin schoolverlaters geografisch mobiel zijn om zich goed in het arbeidsproces te kunnen inpassen wordt de geografische mobiliteit genoemd. Deze 
wordt bepaald door de geografische afstand tussen de gemeentes van de opleidingslocatie en werklocatie te bepalen. ${ }^{17}$ Hoe groter het zoekgebied van een schoolverlater, des te meer kans deze heeft om een passende baan te vinden. Echter, niet iedereen is bereid om over grote afstand te gaan pendelen of verhuizen voor een passende baan. Daarom is de mate waarin schoolverlaters geografisch mobiel zijn een belangrijke factor bij de baankeuze.

Hieronder zullen de verschillende indicatoren over de aansluiting tussen opleiding en beroep worden besproken voor Nederland en het Technogebied, en voor alle schoolverlaters gezamenlijk en schoolverlaters met een technische opleiding afzonderlijk. In tabel 3.2 worden naast de geografische mobiliteit de kans op een baan op niveau, een baan in eigen richting, vast werk en een voltijdbaan weergegeven. Ook is het werkloosheidspercentage van $\mathrm{MBO}$-schoolverlaters en het percentage MBOschoolverlaters dat een vervolgopleiding volgt weergegeven.

Tabel 3.2

Aansluiting tussen opleiding en beroep van gediplomeerde schoolverlaters van het MBO, gemiddelde 1996-2003

\begin{tabular}{|c|c|c|c|c|}
\hline \multirow[t]{2}{*}{ Indicator } & \multicolumn{2}{|c|}{ Nederland } & \multicolumn{2}{|c|}{ Technogebied } \\
\hline & totaal & techniek & totaal & techniek \\
\hline Mobiliteit (in km.) & 23,4 & 26,3 & 21,5 & 24,8 \\
\hline Baan eigen niveau (in \%) & 66 & 64 & 68 & 63 \\
\hline Baan eigen vakrichting (in \%) & 70 & 75 & 72 & 76 \\
\hline Vast werk (in \%) & 81 & 85 & 84 & 89 \\
\hline Voltijdbaan (in \%) & 74 & 91 & 79 & 92 \\
\hline Werkloosheid (in \%) & 4,7 & 3,4 & 2,1 & 2,2 \\
\hline Vervolgopleiding (in \%) & 40 & 40 & 43 & 40 \\
\hline
\end{tabular}

Opm.: In km. voor geografische mobiliteit van werkende schoolverlaters; als percentage van totaal aantal werkende schoolverlaters voor baan op niveau / in eigen vakrichting, vast werk en voltijdbaan; als percentage van beroepsbevolking voor werkloosheid; als Bron: ROA/SIS percentage van totaal aantal diplomeerde schoolverlaters voor vervolgopleiding.

Uit tabel 3.2 is af te lezen dat de gemiddelde afstand tussen de gemeente waar de opleiding gevolgd is en de gemeente waar schoolverlaters werken voor Nederland gemiddeld 23,4 kilometer is. De kleinste gemiddelde afstand tussen locatie van gevolgde opleiding en werklocatie wordt afgelegd in de Corop-gebieden Agglomeratie 's-Gravenhage, Het Gooi en Vechtstreek, Zaanstreek, Zuidwest-Gelderland, Zuidoost-Noord-Brabant en Groot-Amsterdam, namelijk tussen de 7,4 en 16,4 kilometer. Schoolverlaters met de grootste mobiliteit zijn vooral te vinden in de Corop-gebieden Zuidoost-Friesland $(58,1 \mathrm{~km})$, Noord-Drenthe $(41,5 \mathrm{~km})$, Overig Zeeland $(36,7)$ en Zuidoost-Drenthe $(34,7 \mathrm{~km}) .{ }^{18}$ Dit betekent dat de geografische mobiliteit van schoolverlaters in belangrijke mate samenhangt met de bevolkings- en werkgelegenheidsconcentratie van de verschillende gebieden. Ook kan worden

17. Gegevens over de reistijd en -afstand tussen woonadres en opleidingslocatie zijn pas sinds de meting van 2004 beschikbaar.

18. Corop-gebieden zijn hierbij alleen meegenomen als het aantal observaties per Coropgebied minimaal 25 is. In totaal gaat het om bijna 60.000 schoolverlaters van het MBO in het trendbestand 1996-2003. 
afgeleid dat schoolverlaters indien nodig bereid zijn om over een grote afstand te pendelen of te verhuizen.

In het Technogebied ZON is de gemiddelde afstand tussen gemeente van gevolgde opleiding en gemeente van werklocatie iets kleiner dan het landelijke gemiddelde, namelijk 21,5 kilometer. In Noordoost-Noord-Brabant is de afstand het kleinst, namelijk iets meer dan 17 kilometer. In Zuidoost-Noord-Brabant is de gemiddelde afstand tussen opleidings- en werklocatie wat groter. Met 19,3 kilometer blijft deze afstand wel nog beneden het gemiddelde van zowel het Technogebied in totaal als Nederland. In het Noord-Brabantse deel van het Technogebied is de mobiliteit kleiner dan gemiddeld door de relatief grote bevolkings- en werkgelegenheidsconcentratie. In Midden-Limburg ten slotte is de geografische afstand groter: schoolverlaters die hier hun MBO-opleiding hebben gevolgd werken gemiddeld op 27,2 kilometer afstand van de gemeente waar hun opleiding gevestigd is. ${ }^{19}$

Voor de sector techniek valt te verwachten dat de door schoolverlaters afgelegde afstand tussen opleidingslocatie en werklocatie groter is dan voor alle sectoren gemiddeld. De werkgelegenheid in de technische beroepen is immers relatief sterk geconcentreerd op bepaalde industrieterreinen of bij grote bedrijven. In Nederland is de gemiddelde mobiliteit voor MBO-schoolverlaters techniek inderdaad hoger dan voor alle MBO-schoolverlaters, namelijk 26,3 kilometer. In het Technogebied is dit eveneens het geval. Daar legt de MBO-schoolverlater techniek gemiddeld 24,8 kilometer af. Ook nu is de afstand in Noordoost-Noord-Brabant $(22,4 \mathrm{~km})$ het kleinst, gevolgd door Zuidoost-Noord-Brabant (25,5 km) en Midden-Limburg (26,7 km).

MBO-schoolverlaters techniek hebben doorgaans een kleinere kans op een baan op hun eigen niveau dan de gemiddelde MBO-schoolverlater. Dit geldt zowel voor Nederland als voor het Technogebied. Voor alle schoolverlaters gezamenlijk is de kans op een baan op eigen niveau iets hoger in het Technogebied dan in Nederland. Wat betreft de kans op een baan in de eigen vakrichting is er een omgekeerd beeld te zien: MBO-schoolverlaters techniek hebben, zowel in Nederland als in het Technogebied meer kans op een baan in eigen richting dan de gemiddelde MBOschoolverlater. Dit heeft te maken met de beroepsspecifieke aard van technische opleidingen.

In het Technogebied is de kans op een baan in de eigen vakrichting over het algemeen nog iets groter dan in Nederland. Wat de kans op vast werk valt het op dat deze kans in het Technogebied groter is dan in Nederland, waarbij schoolverlaters techniek zowel in het Technogebied als in Nederland meer kans hebben op vast werk dan de gemiddelde MBO-schoolverlater. Eenzelfde beeld is te zien bij de kans op een voltijdbaan. Een schoolverlater met een technische opleiding heeft veel meer kans op een voltijdbaan dan de gemiddelde schoolverlater.

19. Dit gegeven kan enigszins zijn vertekend omdat de werkende schoolverlaters die in Noord-Limburg hebben gestudeerd tot de schoolverlaters van Midden-Limburg - met als schoollocatie de hoofdvestiging Roermond in plaats van de nevenlocatie Venlo - worden gerekend. Voor Noord-Limburg zijn er geen betrouwbare gegevens beschikbaar omdat er geen hoofdvestiging van een ROC is. 
De hierboven besproken gegevens hebben betrekking op werkende MBO-schoolverlaters. In tabel 3.2 worden ook gegevens gepresenteerd over de werkloosheid en doorstroom in een vervolgopleiding na het MBO. Het werkloosheidspercentage (gediplomeerde MBO-schoolverlaters op de arbeidsmarkt zonder werk van minimaal 12 uur per week) is gemiddeld in Nederland hoger dan in het Technogebied. In Nederland zijn MBO-schoolverlaters techniek minder vaak werkloos dan de gemiddelde MBO-schoolverlater. In het Technogebied is er nauwelijks verschil tussen techniek en totaal MBO. Het aantal MBO-schoolverlaters dat een vervolgopleiding volgt is vrijwel gelijk voor zowel Nederland als het Technogebied en voor zowel totaal als techniek. Over het algemeen volgt de gemiddelde MBOschoolverlater iets vaker een vervolgopleiding dan de schoolverlater met een technische opleiding. Een verklaring hiervoor is het hogere aandeel van BBLleerlingen bij technische MBO-opleidingen (een derde versus de helft voor alle sectoren gemiddeld, zie hoofdstuk 2). BBL'ers nemen minder vaak aan een vervolgopleiding deel dan BOL'ers, met name door het praktijkgerichte karakter van hun opleiding en hun vaak verregaande betrokkenheid bij de bedrijven waar ze werken. Tevens zou men kunnen stellen dat het HBO nog niet voldoende is ingericht op doorstromers vanuit het BBL.

\subsection{Doorstroom binnen de beroepskolom na MBO}

In deze paragraaf wordt achtereenvolgens ingegaan op de doorstroom binnen de beroepskolom na het behalen van het MBO-diploma, de instroom van MBOgediplomeerden in het $\mathrm{HBO}$, en de ontwikkeling van het aantal HBO-leerlingen. Hierbij wordt telkens onderscheid gemaakt tussen Nederland en het Technogebied, en de groep van schoolverlaters van de sector techniek versus de totale groep van schoolverlaters.

\section{Doorstroom na $\mathrm{MBO}$}

Uit tabel 3.2 bleek dat ongeveer $40 \%$ van de MBO-schoolverlaters een vervolgopleiding kiest. Gezien dit hoge percentage is het van belang om na te gaan voor welke vervolgopleidingen deze doorleerders kiezen. Zij kunnen een MBO-opleiding uit een andere richting volgen, of een opleiding die aansluit op hun vorige opleiding, maar dan op een hoger niveau. Schoolverlaters van niveau 1/2 kunnen doorstromen naar niveau 3/4. Een groot deel van de MBO-gediplomeerden stroomt door naar het $\mathrm{HBO}$. Deze doorstroom is enerzijds een functie van het MBO, maar anderzijds een verlies aan arbeidskrachten op MBO-niveau. In tabel 3.3 zijn de vervolgopleidingen van MBO-schoolverlaters weergegeven tussen 1996 en 2003.

Uit de tabel blijkt dat landelijk 66\% van de MBO-schoolverlaters die een vervolgopleiding volgen (ongeveer $40 \%$, zie hierboven), doorstroomt naar het HBO. Voor de sector techniek is dit ongeveer $1 \%$ lager. In het Technogebied kiest $64 \%$ van de 'doorleerders' voor het HBO. In het Technogebied maakt slechts $61 \%$ van de doorlerende $\mathrm{MBO}$-schoolverlaters met een technische opleidingsachtergrond de keuze voor het HBO. Het grootste deel van de MBO-schoolverlaters dat in het MBO verder leert, kiest voor een opleiding op niveau 3/4. Een MBO-vervolgopleiding op 
niveau $1 / 2$ is meestal alleen een optie voor degenen die geen startkwalificatie hebben (i.e. niveau 1) en een opleiding op niveau 2 willen volgen. In het Technogebied blijken vooral de technische BBL-opleidingen op niveau 3/4 populair. Dit is mogelijkerwijs een gevolg van de relatief grote werkgelegenheid in de industrie in het Technogebied (zie ook hoofdstuk 4), waardoor er gemakkelijker BPV-plaatsen (leerlingplaatsen) bij werkgevers kunnen worden gecreëerd. De relatief grote doorstroom naar BBL-opleidingen op niveau 3/4 en de relatief lage doorstroom naar HBO-opleidingen zou ook kunnen samenhangen met een gemiddeld lager niveau van de uitstroom uit het MBO in het Technogebied. Bij de uitstroom uit het VMBO was er echter geen indicatie van een lager niveau van de gediplomeerde schoolverlaters als dat afgemeten wordt naar het niveau van de vervolgopleiding (tabel 3.1). ${ }^{20}$

Tabel 3.3

Vervolgopleiding van MBO-gediplomeerden, als percentage van het totaal aantal MBOgediplomeerden dat een vervolgopleiding volgt, gemiddelde 1996-2003

\begin{tabular}{|c|c|c|c|c|}
\hline \multirow[t]{2}{*}{ Vervolgopleiding } & \multicolumn{2}{|c|}{ Nederland } & \multicolumn{2}{|c|}{ Technogebied } \\
\hline & totaal & techniek & totaal & techniek \\
\hline BOL niveau $1 / 2$ & 2 & 2 & 3 & 3 \\
\hline BOL niveau $3 / 4$ & 15 & 13 & 16 & 12 \\
\hline BBL niveau $1 / 2$ & 3 & 5 & 3 & 4 \\
\hline BBL niveau 3/4 & 13 & 15 & 14 & 20 \\
\hline $\mathrm{HBO}$ & 66 & 65 & 64 & 61 \\
\hline Anders & 1 & 1 & 1 & 0 \\
\hline Totaal & 100 & 100 & 100 & 100 \\
\hline
\end{tabular}

Bron: ROA/SIS

Van alle MBO-schoolverlaters in Nederland gaat 24\% een technische vervolgopleiding doen binnen het $\mathrm{MBO}$ dan wel op het $\mathrm{HBO} .^{21}$ In het Technogebied ligt dit percentage beduidend hoger, namelijk 33\% van alle MBO-schoolverlaters. Landelijk stroomt $78 \%$ van de MBO-schoolverlaters techniek door naar een technische vervolgopleiding. In het Technogebied is het percentage doorstroom van MBOschoolverlaters binnen de richting eveneens beduidend hoger dan landelijk, namelijk $7,5 \% .{ }^{22}$ Over heel Nederland verliest techniek dus 22\% van de MBO-schoolverlaters aan andere richtingen, terwijl dit in het Technogebied beperkt blijft tot $12,5 \%{ }^{23}$

\section{Instroom in $\mathrm{HBO}$}

Van de MBO-gediplomeerden die een vervolgopleiding kiezen stroomt een aanzienlijk deel door naar een HBO-opleiding. Alleen de gediplomeerden van een MBOopleiding niveau 4 (en in bepaalde gevallen ook niveau 3 ) hebben de mogelijkheid

20. Nader onderzoek zou moeten uitwijzen waarom het aandeel dat vanuit het MBO naar het HBO doorstroomt relatief klein is.

21. De gegevens in deze alinea zijn niet in een tabel opgenomen.

22. Hierbij dient aangetekend te worden dat deze schoolverlaters minder vaak doorstromen naar een HBO-opleiding dan landelijk het geval is (zie tabel 3.3).

23. Uiteraard zijn er ook schoolverlaters van niet-technische MBO-opleidingen die een technische vervolgopleiding kiezen, maar dat komt relatief weinig voor. 
om deze overstap te maken. Uit tabel 3.2 bleek dat $40 \%$ van het totaal aantal MBOgediplomeerden kiest voor een vervolgopleiding. Bij de BOL-gediplomeerden is dit bijna 50\%. Van de BOL-gediplomeerden op niveau 3/4 uit de sector techniek die voor een vervolgopleiding kiezen, gaat $89 \%$ een HBO-opleiding doen. Van de BBLgediplomeerden techniek op niveau $3 / 4$ is dit slechts $14 \%$ (zie ook Van Eijs, 2003). ${ }^{24}$ Zoals eerder opgemerkt nemen BBL'ers minder vaak aan een vervolgopleiding deel dan BOL'ers door het praktijkgerichte karakter van hun opleiding (die zich minder leent voor doorstroom naar het HBO) en hun vaak verregaande betrokkenheid bij de bedrijven waar ze werken.

In tabel 3.4 is de hoogst voltooide vooropleiding van HBO-gediplomeerden weergegeven. Uit onderstaande tabel wordt duidelijk dat het merendeel van de HBO'ers direct afkomstig is uit het Voortgezet Onderwijs.

Tabel 3.4

Hoogst voltooide vooropleiding van $\mathrm{HBO}$-gediplomeerden, als percentage van het totaal aantal gediplomeerden van het HBO, 1996-2003

\begin{tabular}{|c|c|c|c|c|}
\hline \multirow[t]{2}{*}{ Vooropleiding } & \multicolumn{2}{|c|}{ Nederland } & \multicolumn{2}{|c|}{ Technogebied } \\
\hline & totaal & techniek & totaal & techniek \\
\hline HAVO & 43 & 34 & 42 & 29 \\
\hline VWO & 28 & 27 & 26 & 28 \\
\hline MBO & 26 & 35 & 29 & 39 \\
\hline $\mathrm{HBO}$ & 2 & 2 & 2 & 2 \\
\hline Andere vooropleiding & 2 & 2 & 2 & 2 \\
\hline Totaal & 100 & 100 & 100 & 100 \\
\hline
\end{tabular}

Bron: ROA/SIS

Van alle gediplomeerde HBO'ers in Nederland en het Technogebied is het grootste deel, 43 respectievelijk 42\%, afkomstig uit het HAVO, terwijl het aandeel schoolverlaters met VWO als vooropleiding vrij constant is voor alle vier de groepen (rond de $27 \%$ ). HBO'ers van de sector techniek hebben ten opzichte van de andere HBO'ers beduidend vaker een MBO-opleiding als hoogste vooropleiding, en significant minder vaak een HAVO-opleiding. In Nederland heeft 35\% van de HBOschoolverlaters techniek een MBO-opleiding als hoogst voltooide vooropleiding, in het Technogebied is dit zelfs 39\%. Voor de totale groep van afgestudeerden van het HBO liggen deze percentages lager, namelijk $26 \%$ voor Nederland en $29 \%$ voor het Technogebied. Geconcludeerd kan worden dat de doorstroom binnen de (technische) beroepskolom in het Technogebied beter is dan voor Nederland als geheel.

In figuur 3.4 zijn respectievelijk het totaal aantal HBO-leerlingen en het aantal leerlingen van technische $\mathrm{HBO}$-opleidingen in Nederland weergegeven. In de figuur zien we dat het aantal HBO-leerlingen in de afgelopen zeven jaar gestaag is gestegen. Waren er in 1997/'98 nog ongeveer 280.000 leerlingen, in 2003/'04 is dit aantal gestegen naar ruim 332.000 leerlingen. Volgens het CBS (2002) wordt de

24. De doorstroompercentages die in de verschillende onderzoeken gepubliceerd worden kunnen echter verschillen, afhankelijk van de exacte definities, de periode en het bronmateriaal. 
groei van het aantal HBO-leerlingen veroorzaakt door een hogere onderwijsdeelname van leerlingen ouder dan 22. De verwachting is dat de stijging in de toekomst zal blijven doorzetten, ook omdat middelbare scholieren steeds vaker voor het HAVO of het VWO kiezen dan voor het VMBO. Havisten geven relatief vaak de voorkeur aan een HBO-opleiding ten opzichte van een MBO-opleiding (CBS, 2002).

Figuur 3.4

Aantal leerlingen van HBO-opleidingen in Nederland (NL), totaal en techniek, 1997/'98-2003/'04

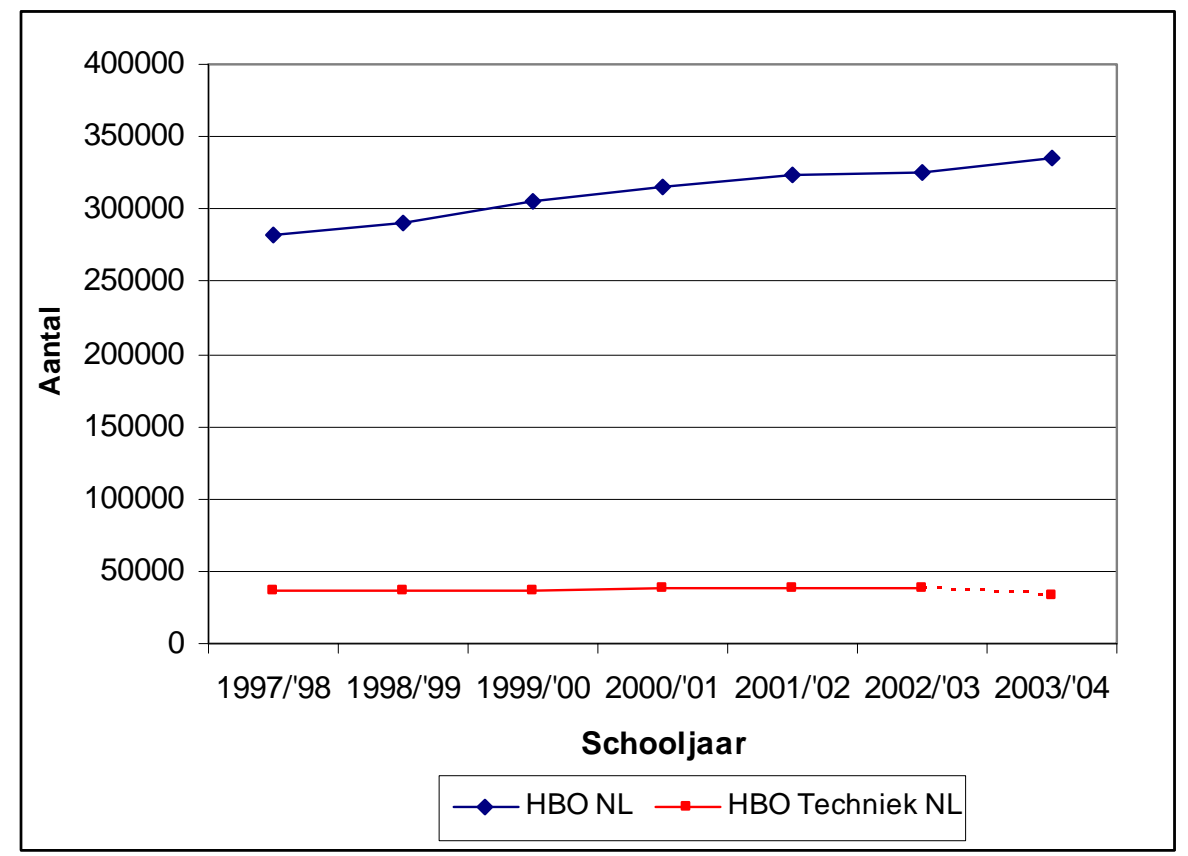

Bron: ROA/CBS

Het aantal leerlingen van technische HBO-opleidingen stijgt van 35.200 naar bijna 37.600 leerlingen, waarna het aantal weer iets terugloopt naar bijna 37.000 leerlingen in 2002/'03. In het laatste jaar lijkt er een relatief grote daling op te treden, maar deze wordt waarschijnlijk volledig veroorzaakt door het gebruik van andere definities en rekenmethodes. ${ }^{25}$

Voor het Technogebied zien de grafieken er gelijksoortig uit. In figuur 3.5 is het totaal aantal HBO-leerlingen en het totaal van leerlingen aan technische HBO-opleidingen weergegeven voor het Technogebied. ${ }^{26}$

25. Vanaf het opleidingsjaar 2003/'04 is er een trendbreuk omdat de gegevens zijn gebaseerd op uitkomsten van het 'Project ééncijfer Hoger Onderwijs'. In dit project werken het CBS, de IB-groep, de HBO-raad, de VSNU, Cfi en het ministerie van OCW samen om bij publicaties over het hoger onderwijs van dezelfde bronbestanden (i.c. dezelfde afslag vanhet CRIHO) gebruik te maken en met uniforme definities en berekeningsmethoden te werken.

26. Zie Bijlage 4 voor een overzicht van de gemeentes met HBO-vestigingen in het Technogebied en Zuid-Limburg. 
Figuur 3.5

Aantal leerlingen van HBO-opleidingen in het Technogebied (TG), totaal en techniek, 1997/'982003/'04

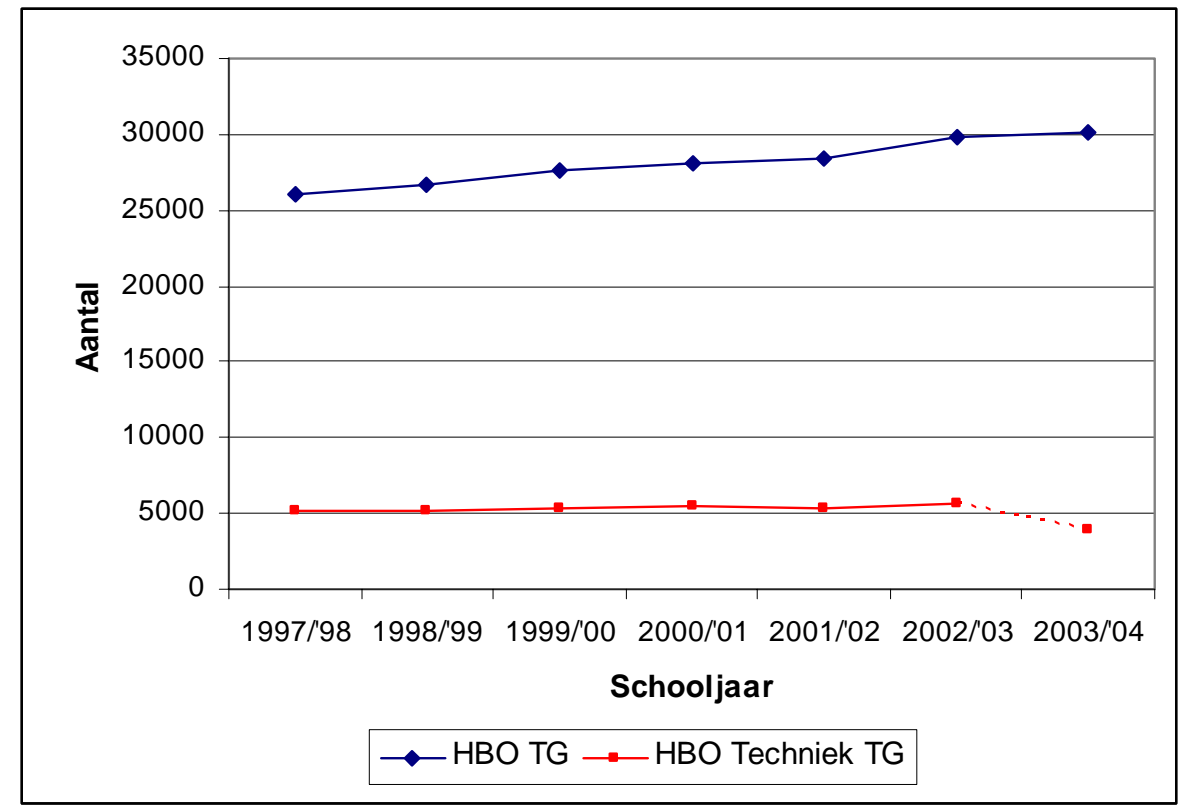

Bron: ROA/CBS

Uit de figuur blijkt dat het totaal aantal HBO-leerlingen in het Technogebied stijgt van 26.000 naar ruim 30.000. Echter hier is de toename minder sterk dan voor Nederland als geheel. De sector techniek groeide daarentegen iets meer (in \%) in het Technogebied dan in heel Nederland, namelijk van 5.200 naar ruim 5.600 leerlingen in het jaar 2002/'03. Ook hier is de daling van het aantal HBO-leerlingen in de sector techniek in het laatste jaar waarschijnlijk vrijwel volledig toe te schrijven aan het gebruik van andere definities en rekenmethoden (zie eerdere voetnoot).

In figuur 3.6 is het aandeel HBO-leerlingen techniek van het totaal aantal HBOleerlingen weergegeven. Opvallend in deze figuur is het grote verschil in aandeel techniek tussen Nederland en het Technogebied, namelijk respectievelijk bijna 13 en ruim $20 \%$ in. Het verschil blijft tussen 1997/'98 en 2002/'03 vrij stabiel, tussen de 7 en $8 \%$-punten. Het aandeel leerlingen techniek van het totaal aantal leerlingen neemt zowel in het Technogebied als in Nederland met ruim 1\%-punt af. ${ }^{27}$

Over het algemeen kan gesteld worden dat door de flinke toename van het totaal aantal HBO-leerlingen de afnemende belangstelling voor de technische opleidingen wordt gecompenseerd, waardoor het totale aantal HBO-leerlingen dat voor techniek kiest stijgt. Wat betreft de ontwikkeling van het leerlingenaantal in de sector techniek lijkt de situatie in het $\mathrm{HBO}$ minder ernstig dan in het VMBO en MBO.

27. De wijziging in de definities en de rekenmethode van het CBS verandert overigens het aandeel techniek sterker voor het Technogebied dan voor Nederland als geheel. 
Figuur 3.6

Percentage leerlingen techniek van het totaal aantal HBO-leerlingen in Nederland (NL) en in het Technogebied (TG), 1997/'98-2003/'04

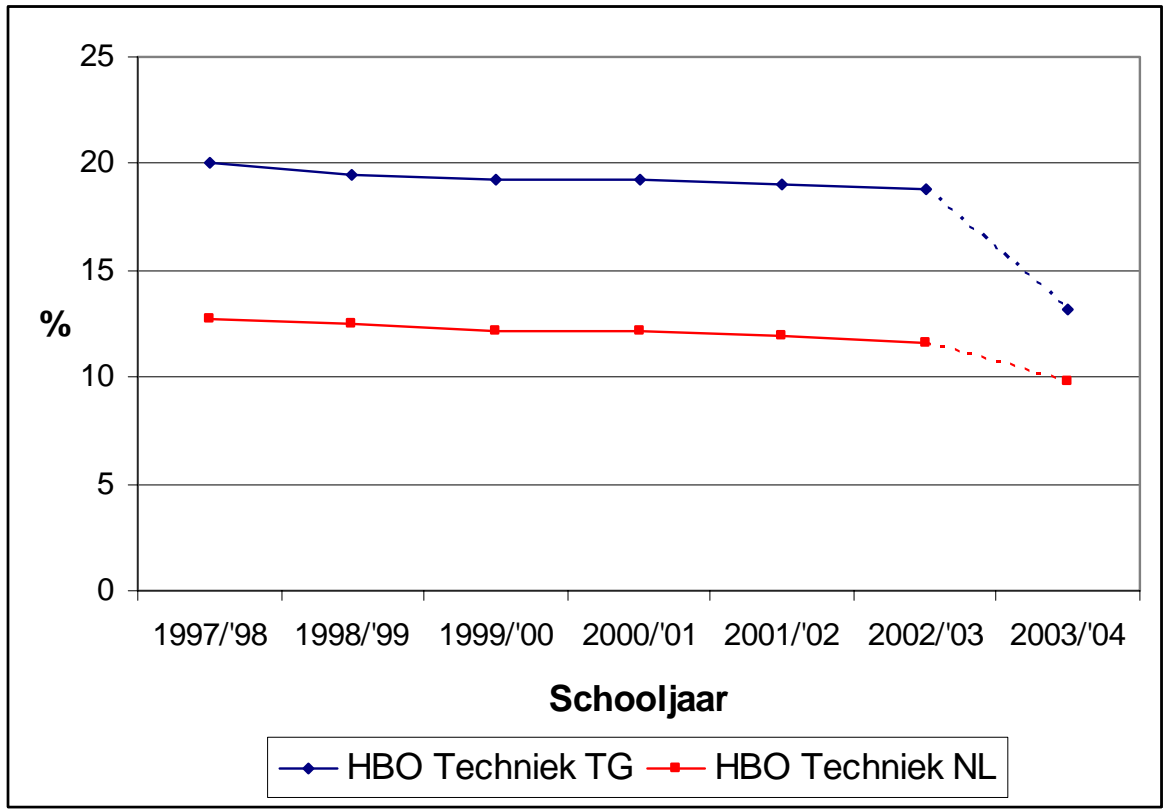

Bron: ROA/CBS

\subsection{Arbeidsmarktintrede na HBO}

De arbeidsmarktintrede van HBO'ers kan op soortgelijke wijze als voor MBO'ers (zie paragraaf 3.2) worden geanalyseerd. Daarvoor worden de resultaten uit de HBOmonitor gebruikt. In tegenstelling tot de RUBS-enquête (steekproef) voor het MBO wordt de HBO-monitor naar vrijwel alle afgestudeerden verstuurd. Beide enquêtes bevatten echter eenzelfde kernvragenlijst. Tabel 3.5 is samengesteld op basis van gegevens van de HBO-monitor. Het blijkt dat onder HBO'ers de geografische mobiliteit veel hoger is dan onder MBO'ers.

In de tabel is te zien dat de gemiddelde afgestudeerde van het HBO in Nederland 39,4 kilometer aflegt van de gemeente waar de opleiding is gevolgd tot de gemeente waar hij werkzaam is. De over het algemeen grotere mobiliteit van afgestudeerden van het $\mathrm{HBO}$ is te verklaren door een lagere baandichtheid van de hogere beroepen dan van de middelbare beroepen. Ook zijn HBO'ers meer bereid om te verhuizen of over een grotere afstand te pendelen dan MBO'ers (zie bijv. Borghans et al., 2005). $\mathrm{Bij} \mathrm{HBO}$-afgestudeerden in de sector techniek is de geografsiche mobiliteit zelfs 43,3 kilometer, vergelijkbaar met de meest mobiele MBO-schoolverlaters in enkele dunbevolkte Corop-gebieden. In het Technogebied is de geografische mobiliteit van afgestudeerden van het HBO lager, namelijk 35,3 kilometer. Voor de afgestudeerden van HBO techniek is dit met 34,2 kilometer zelfs nog iets minder. Dit is opmerkelijk gezien de over het algemeen grotere werkgelegenheidsconcentratie van industriële activiteiten, en de hogere mobiliteit van MBO'ers techniek ten opzichte van andere 
MBO'ers. In het Technogebied zijn er kennelijk relatief veel goed aansluitende banen op korte afstand van de opleidingslocatie beschikbaar voor HBO-afgestudeerden in de technische richtingen.

Tabel 3.5

Aansluiting tussen opleiding en beroep van HBO-gediplomeerden, 1996-2003

\begin{tabular}{|c|c|c|c|c|}
\hline \multirow[t]{2}{*}{ Indicator } & \multicolumn{2}{|c|}{ Nederland } & \multicolumn{2}{|c|}{ Technogebied } \\
\hline & totaal & techniek & totaal & techniek \\
\hline Mobiliteit (in km.) & 39,4 & 43,3 & 35,3 & 34,2 \\
\hline Baan eigen niveau (in \%) & 78 & 84 & 78 & 84 \\
\hline Baan eigen vakrichting (in \%) & 77 & 83 & 81 & 81 \\
\hline Vast werk (in \%) & 83 & 85 & 85 & 86 \\
\hline Voltijdbaan (in \%) & 78 & 95 & 83 & 96 \\
\hline Werkloosheid (in \%) & 4,2 & 3,3 & 3,1 & 3,2 \\
\hline Vervolgopleiding (in \%) & 25 & 25 & 25 & 23 \\
\hline
\end{tabular}

\footnotetext{
Opm.: In km. voor geografische mobiliteit van werkende schoolverlaters; als percentage van totaal aantal werkende schoolverlaters voor baan op niveau / in eigen vakrichting, vast werk en voltijdbaan; als percentage van beroepsbevolking voor werkloosheid; als Bron: ROA/SIS percentage van totaal aantal schoolverlaters voor vervolgopleiding.
}

Een andere aanwijzing voor de relatief grote bereidheid om te pendelen of te verhuizen is het grotere aandeel HBO'ers dat een baan op het eigen opleidingsniveau en binnen de eigen opleidingsrichting vindt ten opzichte van de schoolverlaters van het MBO. Maar liefst $78 \%$ van alle HBO-afgestudeerden vindt een baan op het eigen niveau. Voor het Technogebied is dit percentage gelijk. HBO-afgestudeerden techniek komen nog vaker in een baan op hun eigen niveau terecht dan de ander schoolverlaters. 84\% van de HBO-afgestudeerden techniek in Nederland en het Technogebied vindt een baan op het eigen niveau. Verder vindt $77 \%$ van alle HBO-afgestudeerden een baan binnen de eigen vakrichting. Voor het Technogebied is dat $81 \%$ voor zowel alle richtingen gezamenlijk als voor techniek.

Ook een vaste aanstelling en een voltijdbaan komen bij HBO-afgestudeerden veel vaker voor dan bij schoolverlaters van het MBO. Onder de HBO-afgestudeerden in Nederland en het Technogebied heeft respectievelijk 83 en $85 \%$ van de werkenden een vaste aanstelling. Deze percentages liggen iets hoger voor de HBO'ers techniek. Verder werken HBO-afgestudeerden van de richting techniek beduidend vaker in een voltijdbaan dan gemiddeld. Schoolverlaters van de technische richtingen van zowel het $\mathrm{MBO}$ als het $\mathrm{HBO}$ hebben dus relatief vaak een vaste en een voltijdbaan. Dit komt mede doordat er relatief veel mannen een technische richting volgen.

Het werkloosheidspercentage is ook voor HBO-afgestudeerden in het Technogebied lager dan in Nederland, al is het verschil kleiner dan onder MBO'ers. In het Technogebied is er, net als voor MBO'ers, nauwelijks verschil tussen HBO'ers techniek en de totale groep van afgestudeerden van het HBO. Opmerkelijk is wel dat in het Technogebied de werkloosheid onder afgestudeerde HBO'ers hoger ligt dan die onder afgestudeerde MBO'ers (vergelijk tabel 3.5 met tabel 3.2). Voor Nederland als 
geheel geldt juist het omgekeerde. Het percentage afgestudeerden van het HBO dat aan een vervolgopleiding begint is voor zowel Nederland als het Technogebied ongeveer 25\%. Alleen HBO-afgestudeerden techniek in het Technogebied kiezen relatief minder vaak voor een vervolgopleiding.

\subsection{Conclusies}

Belangstelling voor techniek op VMBO en HBO in Technogebied relatief groot, maar dalende

Evenals in het vorige hoofdstuk meten we de belangstelling voor techniek af naar het aandeel leerlingen en gediplomeerden dat voor een technische opleiding heeft gekozen. In het Technogebied is het aandeel techniek op het VMBO en het HBO (net als voor het MBO, zie hoofdstuk 2) groter dan in Nederland. Het aandeel techniek onder VMBO-gediplomeerden in het Technogebied is in het laatste waargenomen jaar (2002/'03) bijna 23\%, wat ca. 1,5\%-punt meer is dan in Nederland. Ongeveer $20 \%$ van de $\mathrm{HBO}-l e e r l i n g e n$ volgt een technische opleiding. Het verschil met Nederland is met 7 à $8 \%$-punten opvallend groot. In tegenstelling tot het MBO is er op het VMBO en het HBO geen convergentie tussen het Technogebied en Nederland waar te nemen wat betreft het aandeel techniek.

Ook uit dit hoofdstuk is gebleken dat de belangstelling voor techniek dalende is. Dit uit zich in het dalende aandeel leerlingen of gediplomeerden in de technische sector. Deze ontwikkeling geldt voor de gehele beroepskolom, van VMBO tot HBO, en doet zich zowel in Nederland als in het Technogebied voor. De daling van het aandeel techniek voor het VMBO en het $\mathrm{HBO}$ in het Technogebied is met respectievelijk ruim 3 en ruim 1\%-punt beduidend kleiner dan de daling van 9\%-punt voor het MBO in het Technogebied (zie hoofdstuk 2). Bovendien zijn de verschillen met de landelijke ontwikkeling veel kleiner voor het VMBO en het $\mathrm{HBO}$.

Over het algemeen kan gesteld worden dat door de flinke toename van het totaal aantal HBO-leerlingen de afnemende belangstelling voor de technische opleidingen wordt gecompenseerd, waardoor het totale aantal HBO-leerlingen dat voor techniek kiest stijgt. Wat betreft de deelname aan techniek lijkt daardoor de situatie in het $\mathrm{HBO}$ minder ernstig dan in het VMBO en MBO.

Van belang is verder de algemene trend dat het aantal VMBO-gediplomeerden afneemt. Leerlingen kiezen steeds vaker voor het HAVO in plaats van het VMBO als zij de keuze hebben. De afname van het aantal VMBO-leerlingen heeft als gevolg dat het $\mathrm{MBO}$ veel minder sterk zal groeien dan het $\mathrm{HBO}$, en in mindere mate ook het WO (CBS, 2002). Dit heeft tot gevolg dat ook het aantal gediplomeerden in de technische sector van het $\mathrm{VMBO}$ en het $\mathrm{MBO}$ zal afnemen, zelfs als het aandeel van de leerlingen dat voor techniek kiest constant blijft. 
Goede doorstroom binnen de beroepskolom techniek in Technogebied

In het Technogebied is de doorstroom binnen de beroepskolom techniek relatief goed. Ten opzichte van Nederland kiest een iets groter aandeel VMBO'ers voor een vervolgopleiding techniek op het MBO. De doorstroom vanuit het MBO naar het HBO binnen de beroepskolom techniek lijkt beduidend beter te zijn binnen het Technogebied. Over heel Nederland verliest techniek 22\% van de MBO-schoolverlaters aan andere richtingen, terwijl dit in het Technogebied beperkt blijft tot $12,5 \%$. Een kanttekening hierbij is wel dat in het Technogebied wat minder MBO'ers met een technische opleiding lijken door te stromen naar een HBO-opleiding, zowel ten opzichte van andere opleidingen als ten opzichte van Nederland als geheel. Overigens kiest de MBO-schoolverlater met een technische opleiding minder vaak voor een vervolgopleiding op het HBO. Een verklaring hiervoor is het hogere aandeel leerlingen in de beroepsbegeleidende leerweg (BBL) bij technische MBO-opleidingen. In vergelijking met de beroepsopleidende leerweg (BOL) leent deze leerweg zich minder goed voor een vervolgstudie op het HBO. Tevens zou men kunnen stellen dat het $\mathrm{HBO}$ nog niet voldoende is ingericht op doorstromers vanuit het BBL.

\section{Geografische mobiliteit middelbaar technisch opgeleiden relatief groot}

De geografische mobiliteit van schoolverlaters na hun afstuderen hangt in belangrijke mate samen met de bevolkings- en werkgelegenheidsconcentratie in de verschillende regio's. Uit de relatief grote mobiliteit in dunbevolkte gebieden kan worden afgeleid dat schoolverlaters indien nodig bereid zijn om over een grote afstand te pendelen of te verhuizen. In het Technogebied is de geografische mobiliteit (i.e. de afgelegde afstand tussen opleidingslocatie en werklocatie) relatief klein voor zowel MBO'ers als HBO'ers.

Voor afgestudeerden in de sector techniek is de mobiliteit over het algemeen groter dan voor alle sectoren gemiddeld, omdat de werkgelegenheid in de technische beroepen relatief sterk geconcentreerd is op bepaalde industrieterreinen of bij grote bedrijven. In het Technogebied is de gemiddelde mobiliteit voor MBO-schoolverlaters 21,5 kilometer tegenover 24,8 kilometer voor de MBO-schoolverlaters techniek. Het is overigens opmerkelijk dat de mobiliteit van de afgestudeerde HBO'ers in de richting techniek in het Technogebied juist kleiner is dan die van andere HBOafgestudeerden. Voor Nederland als geheel is de mobiliteit van HBO-afgestudeerden techniek wel groter dan die van andere HBO-afgestudeerden.

De beduidend grotere mobiliteit van afgestudeerden van het HBO ten opzichte van MBO-schoolverlaters is te verklaren door een lagere baandichtheid van de hogere beroepen dan van de middelbare beroepen. Ook zijn HBO'ers meer bereid om te verhuizen of over een grotere afstand te pendelen dan MBO'ers.

\section{Arbeidsmarkt in Technogebied relatief krap voor MBO'ers}

De arbeidsmarktintrede van gediplomeerde MBO'ers en HBO'ers verloopt relatief goed in het Technogebied. In het Technogebied hebben afgestudeerden van het 
MBO en het $\mathrm{HBO}$ vaker een vaste en een voltijdbaan, die ook beter aansluit op het niveau en de richting van de gevolgde opleiding. Bovendien hoeft men, afgemeten naar de afstand tussen de gemeente waar de opleiding is gevolgd tot de gemeente waar men werkt, minder ver te pendelen. Tot slot is de werkloosheid onder afgestudeerden van het MBO en het HBO beduidend lager in het Technogebied ten opzichte van Nederland.

De regionale verschillen zijn relatief klein vergeleken met de verschillen tussen techniek en niet-techniek. Hoewel afgestudeerde MBO'ers en HBO'ers met een diploma techniek relatief ver moeten pendelen (of verhuizen), verloopt hun arbeidsmarktintrede relatief goed ten opzichte van afgestudeerden uit andere richtingen. Alleen de werkloosheid lijkt een sterkere regionale component te hebben, omdat deze voor gediplomeerden van zowel het MBO als het HBO duidelijk lager ligt in het Technogebied en er weinig verschil is tussen techniek en de andere opleidingsrichtingen. Opmerkelijk is tot slot dat de gemiddelde werkloosheid in het Technogebied tussen 1996 en 2003 onder afgestudeerde MBO'ers lager was (zowel voor techniek als totaal) dan onder afgestudeerde HBO'ers. Voor Nederland als geheel was juist de werkloosheid onder de afgestudeerde HBO'ers lager.

De analyse van de arbeidsmarktintrede laat zien dat de arbeidsmarkt relatief krap is in het Technogebied, in het bijzonder onder MBO'ers. Er kan op basis van deze analyse niet geconcludeerd worden dat dit in nog sterkere mate geldt voor afgestudeerde MBO'ers en HBO'ers met een technische opleidingsachtergrond. 


\section{Arbeidsmarkt naar beroep en opleiding voor techniek}

De dalende leerlingenaantallen in de technische sector hangen waarschijnlijk voor een deel samen met de dalende werkgelegenheid in de technische beroepen. Dit is een gevolg van de krimpende werkgelegenheid in de industrie en de daaraan gerelateerde verdienstelijking van de werkgelegenheid. ${ }^{28}$ In dit hoofdstuk wordt de werkgelegenheidsontwikkeling in de technische beroepen afgezet tegen de totale werkgelegenheidsontwikkeling in zowel het Technogebied als Nederland. Hiermee wordt een indicatie van de ontwikkeling van de relatieve vraag naar technisch opgeleiden in het Technogebied verkregen. Verder zal de arbeidsmarktpositie van het relatief grote aandeel technisch opgeleiden in het Technogebied worden vergeleken met de arbeidsmarktpositie van technisch opgeleiden in Nederland. Er wordt daarbij gekeken naar de ontwikkeling van de werkloosheid en de arbeidsparticipatie, en de mate waarin technisch opgeleiden van de verschillende opleidingsniveaus binnen de beroepskolom (VMBO, MBO, HBO) werkzaam zijn in een technisch beroep. Op deze wijze wordt een indicatie verkregen van de ernst van de schaarste aan technisch opgeleiden in het Technogebied.

Er wordt gebruik gemaakt van de gegevens uit de Enquête Beroepsbevolking $(\mathrm{EBB})^{29}$ om de ontwikkeling van de totale werkgelegenheid en de werkgelegenheid in de technische beroepen weer te geven. Het gaat hierbij om de werkgelegenheid uitgedrukt in werkzame personen tussen 15 en 64 jaar oud, die voor minimaal 12 uur per week betaald werk verrichten. Er wordt verder gebruik gemaakt van de Standaard BeroepenClassificatie (SBC) van het CBS en de daarmee samenhangende beroepenclassificatie van het ROA (2002) om de technische en de niet-technische beroepen te onderscheiden. Bovendien worden twee aan de technische beroepen gerelateerde beroepsgroepen onderscheiden, te weten de wiskundige en natuurwetenschappelijke beroepen (waaronder laboratoriumpersoneel) en de niettechnische ICT-beroepen (waaronder programmeurs). De afbakening tussen technische, aan techniek grenzende en niet-technische beroepen is opgenomen in Bijlage 6. De Enquête Beroepsbevolking wordt ook gebruikt om de werkgelegenheidsontwikkeling en de arbeidsmarktpositie van de technisch opgeleiden in het Technogebied en Nederland weer te geven. Voor het onderscheid tussen technische

28. Zie verder ook De Grip en Dijksman (2004) over de veranderingen in de werkgelegenheid en de overgang naar een 'handelskenniseconomie'.

29. De Enquête Beroepsbevolking (EBB) van het CBS is een onderzoek onder personen van 15 jaar en ouder die in Nederland wonen, met uitzondering van personen in inrichtingen, instellingen en tehuizen (institutionele bevolking). De steekproef wordt sinds 1987 gehouden en bevat ongeveer 90.000 personen. In de EBB worden naast persoons- en huishoudenskenmerken onder meer gegevens verzameld over de arbeidsmarktpositie, het arbeidsmarktverleden en het opleidingsniveau. Vanaf 1996 is de weging van de steekproef herzien. Daardoor zijn de gegevens tot en met 1995 niet geheel vergelijkbaar met die vanaf 1996. De EBB-gegevens van 2003 en 2004 naar beroep en opleiding waren nog niet beschikbaar op het moment dat het voorliggende onderzoek werd uitgevoerd. 
en niet-technische opleidingen wordt aangesloten bij de gebruikte afbakening van de twee vorige hoofdstukken (zie ook Bijlage 2).

In paragraaf 4.1 wordt gekeken naar de werkgelegenheidsontwikkeling in de technische beroepen voor Nederland, in paragraaf 4.2 voor het Technogebied. In paragraaf 4.3 wordt de arbeidsmarktpositie van de technisch opgeleiden bekeken. In deze paragraaf wordt ingegaan op het aandeel technisch opgeleiden in de werkende beroepsbevolking en op de werkloosheid, de non-participatie en het werken buiten een technisch beroep onder de technisch opgeleiden van Nederland en het Technogebied. In paragraaf 4.4 volgen de conclusies.

\subsection{Werkgelegenheidsontwikkeling van technische beroepen in Nederland}

In figuur 4.1 is de geïndexeerde werkgelegenheidsontwikkeling van de technische beroepen, de wiskundige en natuurwetenschappelijke beroepen, de niet-technische ICT-beroepen en de overige beroepen weergegeven $(1996=100)$. De wiskundige en natuurwetenschappelijke beroepen en de niet-technische ICT-beroepen gelden als beroepen die verwant zijn aan de technische (ICT-)beroepen. Daarnaast is ook de totale werkgelegenheidsontwikkeling van Nederland weergegeven.

Figuur 4.1

Werkgelegenheidsontwikkeling $(1996=100)$ voor de technische, de aan techniek grenzende, en de overige beroepen, Nederland (NL), 1996-2002

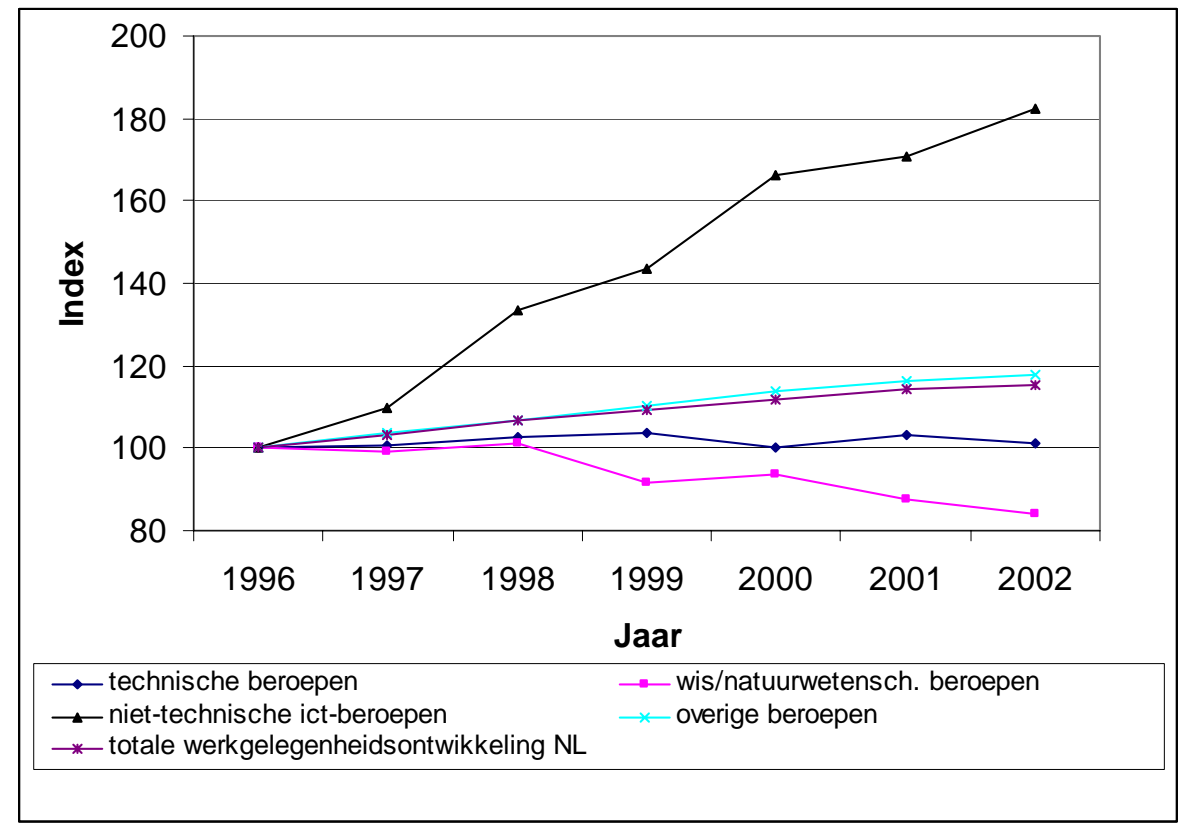

Bron: ROA/CBS

Figuur 4.1 laat zien dat de werkgelegenheid over het algemeen stijgt voor de verschillende beroepsgroepen. In 2002 was er ruim 15\% meer werkgelegenheid dan in 1996. De stijging bedroeg ruim 950.000 werkenden. Daarmee komt de totale 
Nederlandse werkgelegenheid in 2002 uit op 7.141.500 personen. De werkgelegenheid in de technische beroepen is in Nederland sinds 1996 slechts licht gestegen. De werkgelegenheid in de technische beroepen bestond in 2002 uit 1.446 .500 personen, dit zijn ongeveer 17.000 werkzame personen meer dan in 1996. De werkgelegenheidsgroei bedroeg slechts 1,2\% over een periode van 6 jaar. Dit steekt schril af tegen de veel grotere groei van de totale werkgelegenheid.

De werkgelegenheid in de wiskundige en natuurwetenschappelijke beroepen is zelfs aanzienlijk gedaald sinds 1996. In 2002 was het aantal werkzame personen in deze beroepsgroep gedaald met bijna $14 \%$ (ongeveer 7.250 werkzame personen), tot bijna 38.500. De werkgelegenheid in de ICT-beroepen die niet onder de technische beroepen worden geclassificeerd (veelal automatisering) is echter fors gestegen. Dit heeft vooral te maken met de technologische vooruitgang, waardoor het gebruik van ICT-toepassingen in het afgelopen decennium sterk groeide. Tussen 1996 en 2002 groeide de werkgelegenheid in deze beroepen met meer dan 125.000 - dit is $82 \%$ tot bijna 278.000 arbeidsplaatsen.

Van belang is verder het aandeel van elk van deze beroepsgroepen in de totale werkgelegenheid. Dit wordt weergegeven in figuren 4.2 en 4.3 voor respectievelijk 1996 en 2002. In de cirkeldiagrammen is de werkgelegenheid in de technische beroepen, de wiskundige en natuurwetenschappelijke beroepen en de niettechnische ICT-beroepen weergegeven als percentage van de totale werkgelegenheid in Nederland.

\section{Figuur 4.2}

Aandeel van technische, aan techniek grenzende en overige beroepen in de totale werkgelegenheid, Nederland, 1996

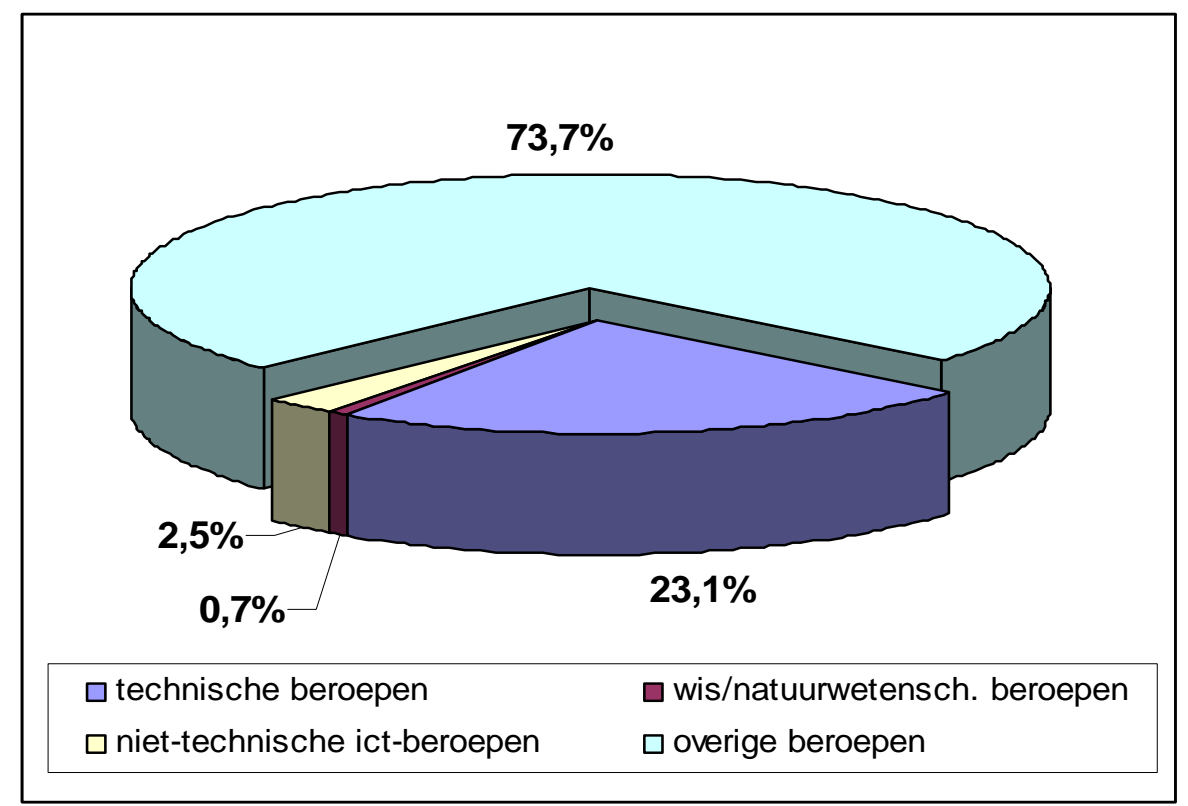

Bron: ROA/CBS 
Uit figuur 4.2 blijkt dat in 1996 het aandeel van de technische beroepen in de werkgelegenheid ongeveer $23 \%$ was. $2,5 \%$ van de werkzame personen werkte toen in de niet-technische ICT-beroepen. De werkgelegenheid in de wiskundige en natuurwetenschappelijke beroepen maakte voor $0,7 \%$ deel uit van de totale Nederlandse werkgelegenheid. De technische en de aangrenzende beroepsgroepen waren samen verantwoordelijk voor ruim $26 \%$ van de werkgelegenheid.

In figuur 4.3 zijn de werkgelegenheidsaandelen in 2002 voor de verschillende beroepsgroepen weergegeven. Er blijkt dat het aandeel van de technische beroepen is gedaald ten opzichte van 1996. In 2002 had iets meer dan $20 \%$ van de werkzame personen in Nederland een baan in een technisch beroep. Dit is een daling van bijna $3 \%$-punten. Tegenover de daling van het werkgelegenheidsaandeel van de technische beroepsgroepen staat een stijging van het aandeel van de niettechnische ICT-beroepen. Dit aandeel stijgt in 2002 naar bijna 4\%. De wiskundige en natuurwetenschappelijke beroepen zijn tussen 1996 en 2002 naar verhouding nog kleiner geworden dan ze al waren. Slechts $0,5 \%$ van de totale werkgelegenheid komt voor in dit soort beroepen. Het werkgelegenheidsaandeel van de technische beroepen inclusief de aangrenzende beroepen is tussen 1996 en 2002 met 1,6\%punten gedaald tot bijna $25 \%$.

\section{Figuur 4.3}

Aandeel van technische, aan techniek grenzende en overige beroepen in de totale werkgelegenheid, Nederland, 2002

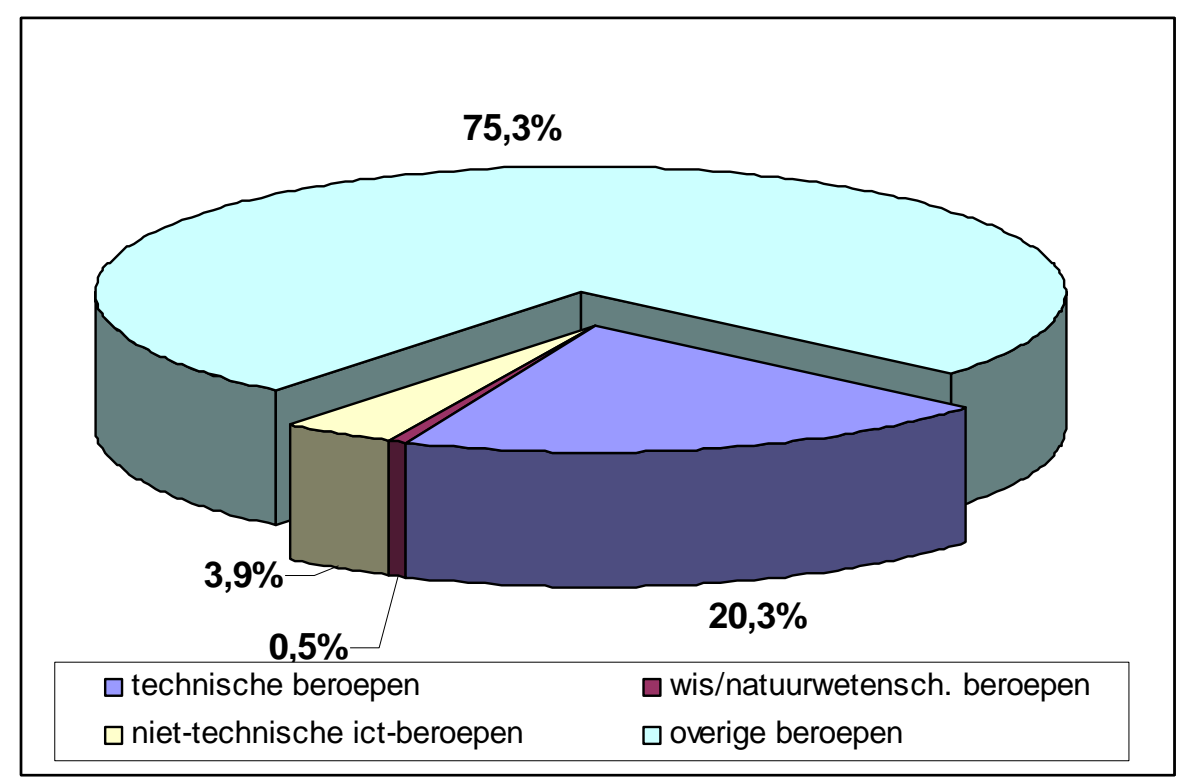

Bron: ROA/CBS 


\subsection{Werkgelegenheidsontwikkeling van technische beroepen in het Technogebied}

Het Technogebied Zuidoost-Nederland is één van de meest geïndustrialiseerde regio's van Nederland, waardoor het voor de hand ligt dat er relatief veel personen in technisch beroepen werken. Eerst wordt hier ingegaan op de werkgelegenheidsontwikkeling van de verschillende beroepsgroepen in het Technogebied voor de periode tussen 1996 en 2002. In figuur 4.4 is de geïndexeerde werkgelegenheidsontwikkeling $(1996=100)$ van de technische beroepen, en de twee aan techniek grenzende beroepsgroepen afgebeeld. Daarnaast laat de figuur ook de totale werkgelegenheidsontwikkeling in het Technogebied zien.

Figuur 4.4

Werkgelegenheidsontwikkeling $(1996=100)$ voor de technische, de aan techniek grenzende, en de overige beroepen, Technogebied (TG), 1996-2002

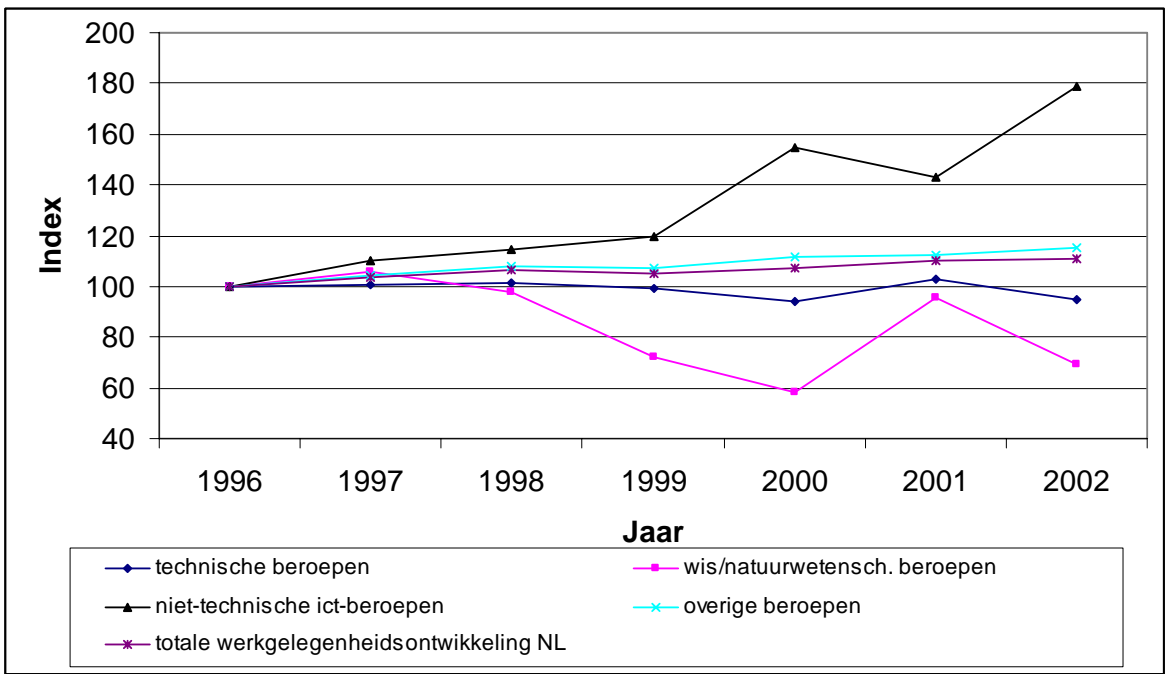

Bron: ROA/CBS

Uit de figuur blijkt dat de totale werkgelegenheid in het Technogebied tussen 1996 en 2002 is gestegen, zij het iets minder sterk dan in Nederland, namelijk met ongeveer $11 \%$ tot ruim 829.500 werkzame personen. In nagenoeg elk jaar was er sprake van een stijgende werkgelegenheid. In 2002 waren er in het Technogebied bijna 83.000 werkzame personen meer dan in 1996. In het Technogebied ligt de werkgelegenheidsgroei dus aanzienlijk lager dan in heel Nederland.

Tussen 1996 en 2002 daalde het aantal werkzame personen in de technische beroepen met ongeveer 5\% van ca. 202.500 naar ca. 192.500, tegenover een lichte stijging in Nederland. De werkgelegenheid in de wiskundige en natuurwetenschappelijke beroepen daalde nog sterker dan in heel Nederland. In 2002 waren er nog geen 3.900 personen werkzaam in deze beroepsgroepen. Dit is ruim $30 \%$ minder dan in 1996. Net als in Nederland steeg de werkgelegenheid in de niet-technische 
ICT-beroepen sterk. Tussen 1996 en 2002 is het aantal werkzame personen in deze beroepen met $79 \%$ gestegen tot ongeveer 30.500 .

In de figuren 4.5 en 4.6 worden de werkgelegenheidsaandelen van de verschillende beroepsgroepen in de totale werkgelegenheid weergegeven voor 1996 respectievelijk 2002.

\section{Figuur 4.5}

Aandeel van technische, aan techniek grenzende en overige beroepen in de totale werkgelegenheid, Technogebied, 1996

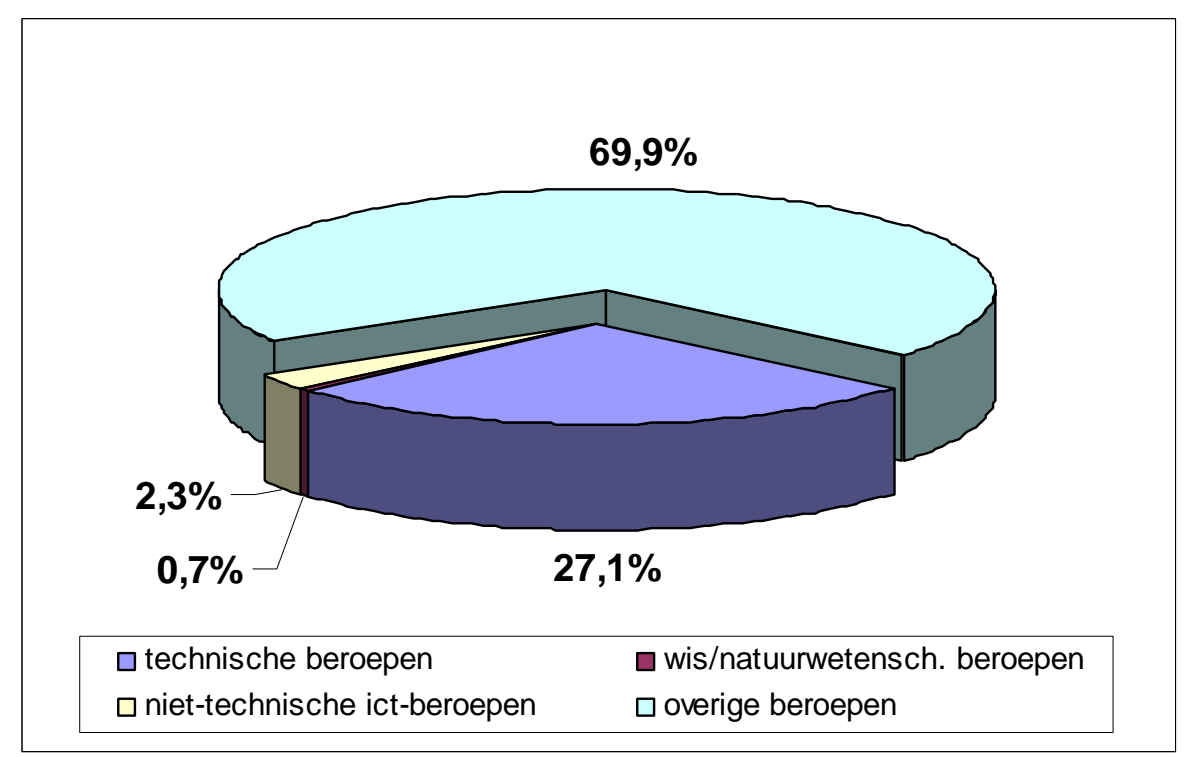

Bron: ROA/CBS

In 1996 is het aandeel van de technische beroepen in de werkgelegenheid in het Technogebied 27\%. De niet-technische ICT-beroepen nemen 2,3\% van de werkgelegenheid voor hun rekening. De wiskundige en natuurwetenschappelijke beroepen nemen, evenals in Nederland, $0,7 \%$ van de werkgelegenheid in het Technogebied in beslag. De werkgelegenheid in het Technogebied bestaat in 1996 dus voor $30 \%$ uit arbeidskrachten werkzaam in de technische en aan techniek grenzende beroepsgroepen.

In 2002 is het werkgelegenheidsaandeel van de technische beroepen met ongeveer 4\%-punten gedaald tot iets meer dan $23 \%$. Deze daling is dus groter dan voor Nederland, waar het werkgelegenheidsaandeel met 3\%-punten afnam. Ook in het Technogebied is het werkgelegenheidsaandeel van de niet-technische ICT-beroepen gestegen. In het Technogebied stijgt dit aandeel in 2002 naar 3,7\%. De daling van het aantal werkzame personen binnen de wiskundige en natuurwetenschappelijke beroepen is in het Technogebied nog sterker geweest dan in Nederland. Nog slechts $0,5 \%$ van de totale werkgelegenheid komt voor in deze beroepen. 
Het werkgelegenheidsaandeel van de technische beroepen inclusief de aangrenzende beroepen is lager dan in 1996, maar wel nog steeds hoger dan in Nederland. Dit werkgelegenheidsaandeel daalt tussen 1996 en 2002 van 30\% naar ruim 27\% van de totale werkgelegenheid in het Technogebied Zuidoost-Nederland. De afname van het werkgelegenheidsaandeel valt - evenals voor Nederland - ongeveer 1\%-punt lager uit als de aangrenzende beroepen worden meegenomen bij de technische beroepen. Dit komt doordat de afname bij de technische beroepen deels gecompenseerd wordt door de stijging van de niet-technische ICT-beroepen.

Figuur 4.6

Aandeel van technische, aan techniek grenzende en overige beroepen in de totale werkgelegenheid, Technogebied, 2002

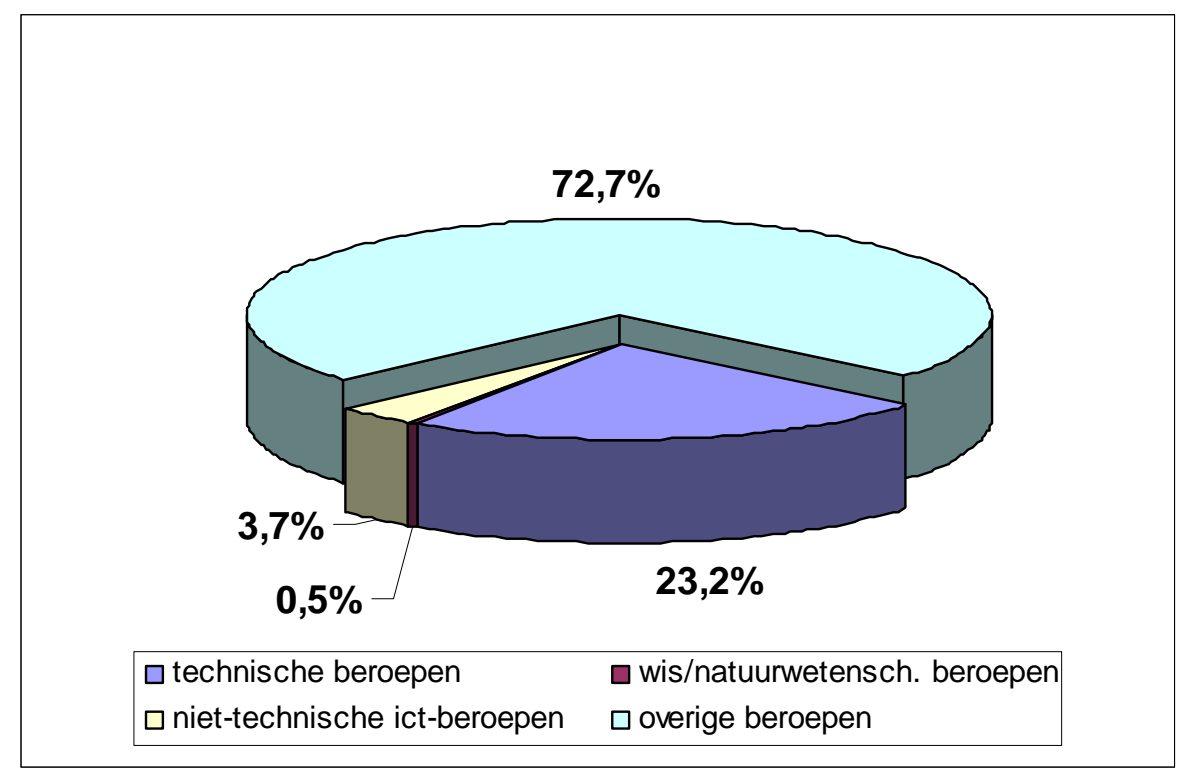

Bron: ROA/CBS

\subsection{Arbeidsmarkt voor technisch opgeleiden in het Technogebied}

Uit paragraaf 4.1 en 4.2 is gebleken dat gedurende de periode 1996-2002 de werkgelegenheid in de technische sector en technische beroepen is afgenomen. Vooral in het Technogebied Zuidoost-Nederland is de werkgelegenheid in de technische beroepen sterk gedaald. De vraag is nu hoe de verandering van de arbeidsmarktpositie van de technisch opgeleiden samenhangt met de werkgelegenheidsontwikkeling in de technische beroepen. In deze paragraaf zal derhalve nader worden ingegaan op de werkloosheid, de non-participatie en mate waarin de werkenden met een technische opleiding terecht komen in een technisch beroep (volgens eerder gebruikte definitie, zie ook Bijlage 6).

Voor de analyse van de arbeidsmarktpositie van de technisch opgeleiden dient er onderscheid te worden gemaakt tussen de werkenden, de werklozen en de niet- 
participerenden. Hierbij wordt gebruik gemaakt van gegevens uit de Enquête Beroepsbevolking (EBB) van het CBS. De totale beroepsbevolking bestaat uit de werkzame en de werkloze beroepsbevolking. De werkzame beroepsbevolking wordt door het CBS gespecificeerd als alle personen tussen 15 en 64 jaar die tenminste twaalf uur per week werken, of die werk hebben aanvaard waardoor ze tenminste twaalf uur per week gaan werken. De werkloze beroepsbevolking bestaat uit personen die verklaren ten minste twaalf uur per week te willen werken, daarvoor beschikbaar zijn en activiteiten ontplooien om werk voor ten minste twaalf uur per week te vinden. Het aantal werklozen gedeeld door de totale beroepsbevolking resulteert in het werkloosheidspercentage. Degenen tussen 15 en 64 jaar oud die werkend noch werkloos zijn behoren tot de zogenaamde niet-participerenden. In dit hoofdstuk wordt de non-participatie uitgedrukt als het percentage niet-participerenden van de potentiële beroepsbevolking (i.e. iedereen tussen 15-64 jaar). ${ }^{30}$

In de volgende subparagraaf wordt eerst ingegaan op de verandering van het aandeel technisch opgeleiden in de werkgelegenheid. Vervolgens wordt aandacht besteed aan de werkloosheid en non-participatie onder de technisch opgeleiden en de mate waarin zij buiten een technisch beroep werkzaam zijn. Er wordt een vergelijking gemaakt tussen het Technogebied en Nederland. Daarbij worden de resultaten van de technisch opgeleide beroepsbevolking afgezet tegen die van de totale beroepsbevolking. Tot slot worden de analyses van de technisch opgeleiden in het Technogebied uitgesplitst naar opleidingsniveau.

\section{Werkgelegenheidsaandeel}

In figuur 4.7 wordt de ontwikkeling weergegeven van het werkgelegenheidsaandeel van technisch opgeleiden in het Technogebied en Nederland voor de periode 19962002. De figuur laat zien dat het aandeel van de werkzame technisch geschoolde beroepsbevolking in het Technogebied hoger is dan voor Nederland. In 1996 waren ruim 202.000 technisch geschoolden werkzaam in het Technogebied. Het aandeel van de technisch geschoolden in de totale beroepsbevolking kwam daarmee uit op 27\%. In Nederland daarentegen had in 1996 maar 23\% (1.422.500 personen) van de werkzame beroepsbevolking een technische opleidingsachtergrond.

Daarnaast valt op dat het aandeel van de technisch opgeleiden in de totale werkzame beroepsbevolking voor zowel het Technogebied als geheel Nederland gedaald is vanaf 1996. In het Technogebied Zuidoost-Nederland daalde het werkgelegenheidsaandeel van $27 \%$ in 1996 naar $24 \%$ in 2002 . Voor Nederland daalde het aandeel technisch opgeleiden van 23\% in 1996 naar 21\% in 2002. De afname van het werkgelegenheidsaandeel van de technisch opgeleiden met 3 respectievelijk 2\%-punten komt zowel voor het Technogebied als voor Nederland overeen met de afname van het werkgelegenheidsaandeel van de technische beroepen 'in brede zin' (dat wil zeggen inclusief de wiskundige en natuurwetenschappelijke beroepen, en de niet-technische ICT beroepen).

30. In de analyse in dit rapport worden scholieren en studenten die regulier onderwijs volgen niet meegeteld bij de potentiële beroepsbevolking. 
Ondanks deze overeenkomstige werkgelegenheidsontwikkeling naar beroep en opleiding is het van belang op te merken dat de relatie tussen opleiding en beroep niet één-op-één is. Dat wil zeggen dat er niet alleen technisch opgeleiden buiten de technische beroepen werken (zie de volgende subparagraaf), maar ook dat er personen zonder een technische opleiding in een technische beroep kunnen werken. Dit laatste kan bijvoorbeeld voorkomen in functies binnen technische beroepen waarvoor weinig scholing is vereist (bijv. hulpkrachten of handlangers van de bakkers, schoenmakers of bouwvakkers), maar ook in functies op een hoger niveau waarbinnen managementvaardigheden een belangrijkere rol spelen (bijv. bedrijfshoofden).

Figuur 4.7

Werkgelegenheidsaandeel van technisch opgeleiden, in procenten van de totale werkzame beroepsbevolking in het Technogebied en Nederland, 1996-2002

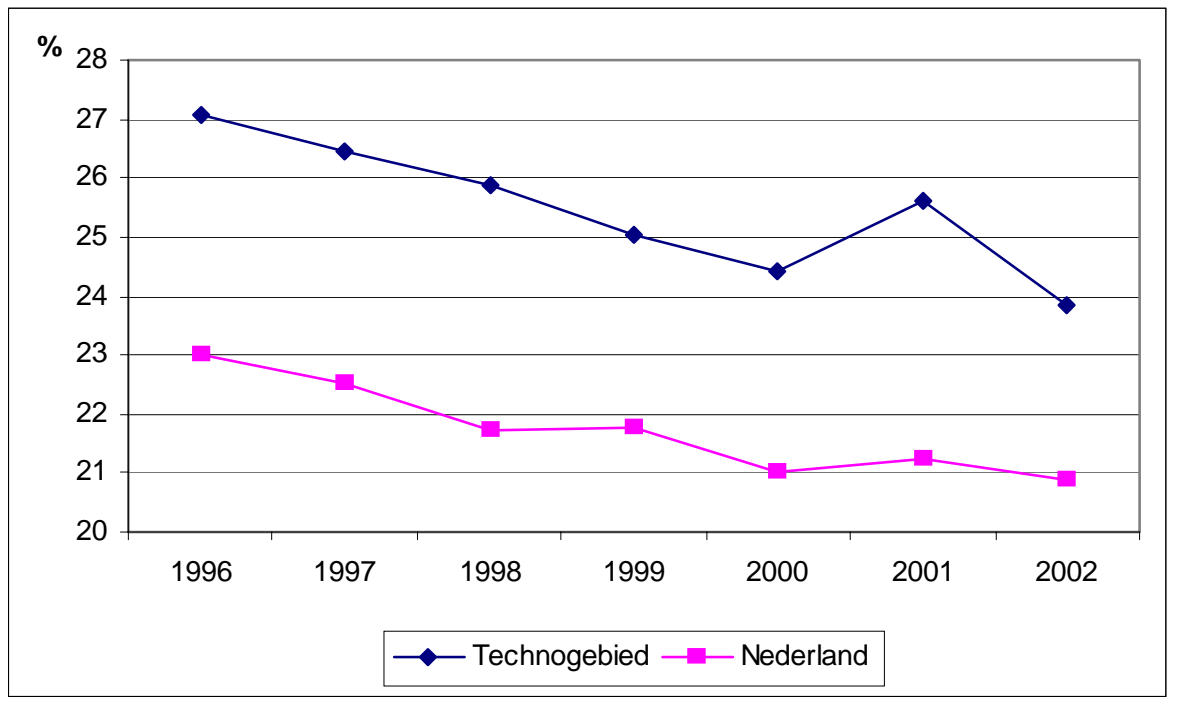

Bron: ROA/CBS

\section{Arbeidsmarktpositie}

De arbeidsmarktpositie van technisch geschoolden wordt bepaald door verschillende factoren. Eén van de belangrijkste factoren is de werkloosheid. Naarmate meer mensen met een bepaalde opleidingsachtergrond werkloos zijn, zullen de baankansen voor een individu met eenzelfde opleidingsachtergrond kleiner zijn. De arbeidsmarktpositie van opleidingen wordt hier niet alleen afgelezen uit de werkloosheidcijfers. Bij het verlies van een baan kan een persoon ook besluiten om uit de arbeidsmarkt te treden. In slechte economische tijden kan een werkgever besluiten eerst de oudere werknemers te laten afvloeien (bijvoorbeeld via de VUT of een Prepensioenregeling). Een andere mogelijkheid is dat langdurig werklozen gedesillusioneerd raken en besluiten niet meer te solliciteren of genoegen nemen met een baan waarin zij minder dan 12 uur werken per week. Als personen 
(vervroegd) uittreden van de arbeidsmarkt, of niet actief zoeken naar een baan van 12 uur of meer worden zij niet gerekend tot de beroepsbevolking, maar worden zij gekenmerkt als non-participanten. Daarom is het van belang dat, naast de werkloosheid, ook gekeken wordt naar de non-participatie.

Een laatste factor die van belang is voor de arbeidsmarktpositie in het kader van dit rapport, is het aandeel van de technisch opgeleiden dat werkzaam is buiten het eigen beroependomein. Als het aandeel technisch opgeleiden werkzaam buiten de eigen vakrichting stijgt, dan kan dit verschillend geïnterpreteerd worden. Enerzijds kan dit er op duiden dat de vraag op de arbeidsmarkt naar personen met de desbetreffende opleidingen achterblijft bij het aanbod. Dit kan dus duiden op een verslechtering van de arbeidsmarktpositie van technisch opgeleiden. Anderzijds kan dit ook duiden op een brede vraag naar technisch opgeleiden vanuit andere niettechnische sectoren en beroepen. Dat laatste is juist positief voor de arbeidsmarktpositie van personen met een technische opleiding.

In figuur 4.8 wordt de werkloosheid weergegeven voor de technisch opgeleiden in het Technogebied en Nederland. In de figuur is het effect van de hoogconjunctuur in de tweede helft van de jaren negentig goed zichtbaar. Vanaf 1996 daalde de werkloosheid voor zowel technisch opgeleiden in het Technogebied als in Nederland. Vanaf 2001 neemt de werkloosheid weer licht toe. Deze ontwikkeling van de werkloosheid onder technisch opgeleiden komt overeen met de totale werkloosheidsontwikkeling tussen 1996 en 2002.

De werkloosheid onder technisch opgeleiden is in het Technogebied relatief laag ten opzichte van Nederland. In 1996 was 3,6\% van de technisch opgeleiden in het Technogebied werkloos, tegenover $4,8 \%$ voor heel Nederland. Het verschil is echter wel in de loop van de tijd afgenomen. In 2002 bedroeg het verschil in werkloosheid onder technisch opgeleiden nog maar 0,1 \%-punt. Deze ontwikkeling kan gedeeltelijk verklaard worden door de achterblijvende werkgelegenheidsgroei in het Technogebied. Zoals bleek uit paragraaf 4.1 en 4.2 was deze ruim 4\%-punt lager dan voor geheel Nederland.

Verder is het van belang op te merken dat de werkloosheid voor de totale beroepsbevolking hoger is dan voor de technisch opgeleiden. In 2002 was deze namelijk $4,1 \%$ voor Nederland en 3,5\% voor het Technogebied. In 1996 was nog 7,5\% van de totale beroepsbevolking in Nederland werkloos, tegen $6,8 \%$ in het Technogebied. Hieruit blijkt tevens dat ook voor de totale beroepsbevolking de werkloosheid relatief laag is in het Technogebied, en dat dit verschil in de betreffende periode nauwelijks afgenomen.

De over het algemeen lagere werkloosheid in het Technogebied is in overeenstemming met de bevindingen in het vorige hoofdstuk over de in het Technogebied lagere werkloosheid onder afgestudeerden van het MBO en HBO op basis van de schoolverlatersgegevens van het ROA. Ook uit de gegevens van de Enquête Beroepsbevolking van het CBS blijkt dat de werkloosheid een regionale dimensie heeft, en niet uitsluitend laag is onder de technisch opgeleiden in het Technogebied. 
Figuur 4.8

Werkloosheid onder technisch opgeleiden in het Technogebied en Nederland, als percentage van de totale beroepsbevolking, 1996-2002

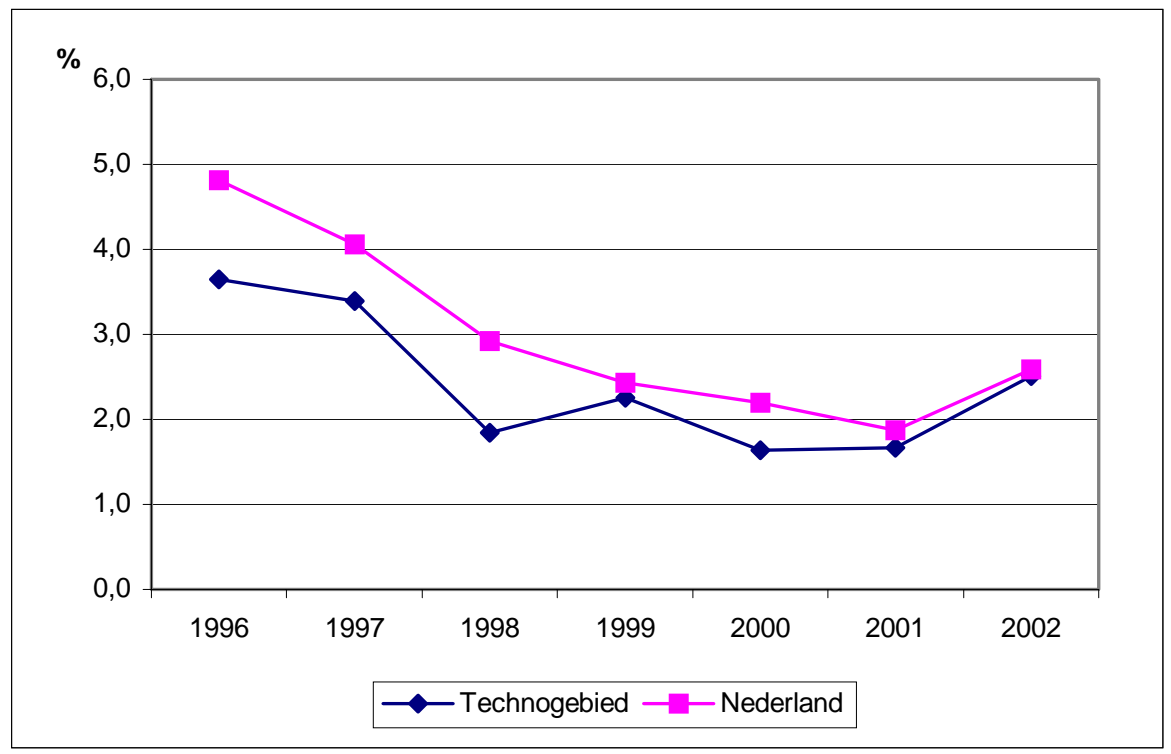

Bron: ROA/CBS

Vervolgens wordt in figuur 4.9 de ontwikkeling van de non-participatie van technisch opgeleiden in de potentiële beroepsbevolking weergegeven voor het Technogebied en Nederland. Mede onder invloed van de conjunctuur is tussen 1996 en 2002 de non-participatie met 3\%-punten van 19,4\% naar 16,4\% gedaald voor zowel het Technogebied als geheel Nederland. De non-participatie van technisch opgeleiden is beduidend lager dan de non-participatie van de totale potentiële beroepsbevolking (alle personen tussen 15 en 64 jaar oud). De totale non-participatie was in 2002 $30,9 \%$ voor het Technogebied en 31,5\% voor heel Nederland. De non-participatie voor de totale potentiële beroepsbevolking in het Technogebied en Nederland is tussen 1996 en 2002 sterker gedaald dan voor de technisch opgeleiden, namelijk met respectievelijk 5,5 en 5,0\%-punten. Dat betekent dat het verschil in nonparticipatie tussen het Technogebied en Nederland voor de totale potentiële beroepsbevolking is toegenomen.

De laatste indicator van de arbeidsmarktpositie die hier besproken wordt, is het aandeel technisch opgeleiden dat werkzaam is buiten de eigen vakrichting. In figuur 4.10 wordt het percentage werkenden buiten de eigen vakrichting weergegeven voor alle technisch opgeleiden in plaats van alleen de schoolverlaters. Bovendien wordt hier de eigen vakrichting anders gedefinieerd, dat wil zeggen niet volgens wat de technisch opgeleide er zelf van vindt (subjectieve maatstaf) maar volgens de lijst van technische beroepen zoals eerder besproken (objectieve maatstaf, zie ook Bijlage 6). 
Figuur 4.9

Non-participatie onder technisch opgeleiden in het Technogebied en Nederland, als percentage van de totale potentiële beroepsbevolking, 1996-2002

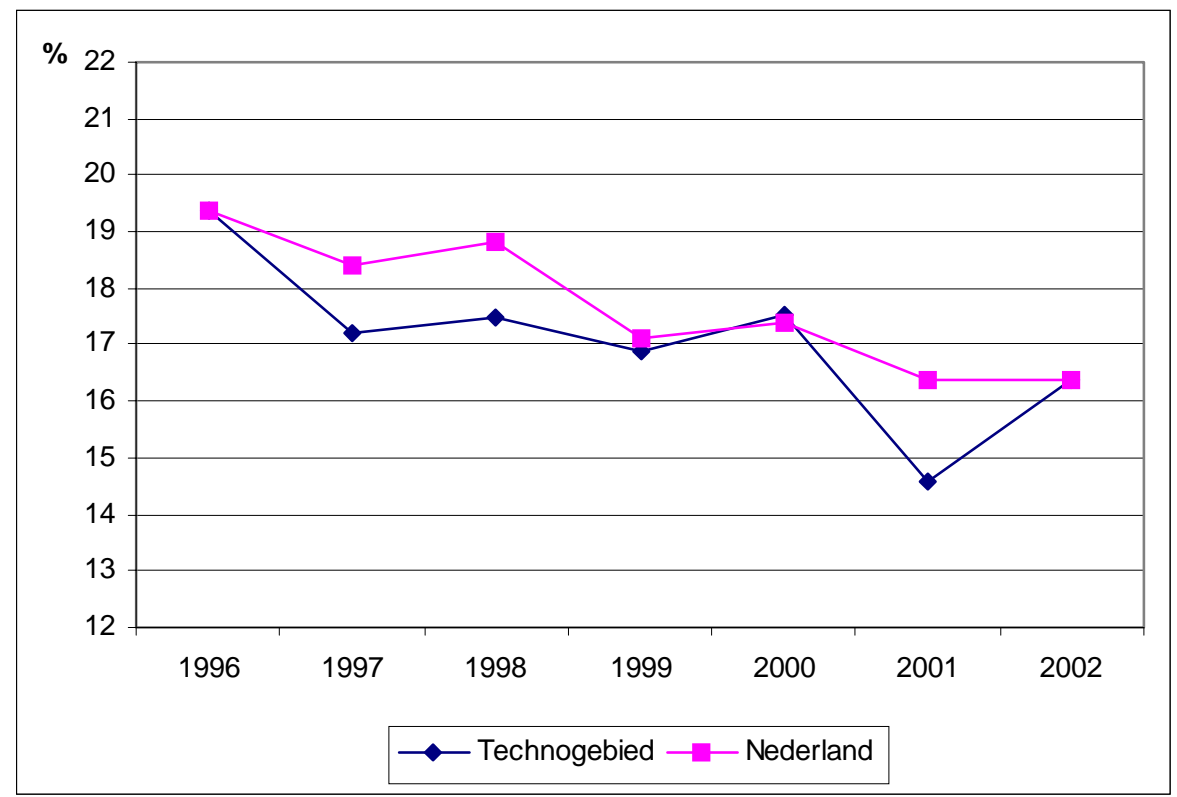

Bron: ROA/CBS

Figuur 4.10

Technisch opgeleiden werkzaam buiten de eigen vakrichting, als percentage van de werkzame beroepsbevolking van technisch opgeleiden, 1996-2002

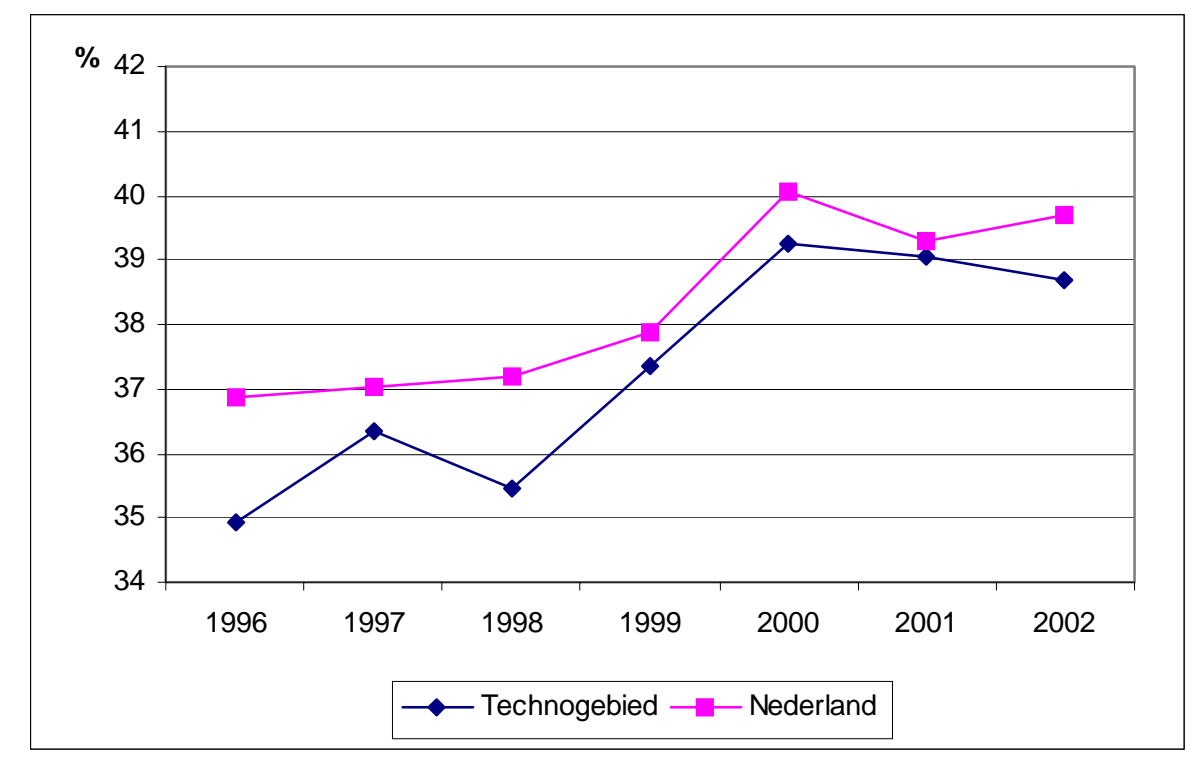

Bron ROA/CBS 
Het percentage technisch opgeleiden dat werkzaam is buiten de eigen vakrichting is groter dan in het vorige hoofdstuk werd vastgesteld. Zoals eerder opgemerkt kan dit zowel te maken hebben met de samenstelling van de groep van technisch opgeleiden als met het op een andere manier vaststellen van de eigen vakrichting. Het werken buiten de eigen vakrichting lijkt in het Technogebied minder voor te komen dan in Nederland. Er gaan dus minder technisch opgeleiden 'verloren' aan andere niet-technische beroepen in het Technogebied.

Daarnaast valt op dat het aandeel van personen dat buiten de eigen (technische) vakrichting werkt toeneemt over de tijd. In Nederland steeg het aandeel over de periode 1996-2002 met 2,8\% tot bijna 40\%. In het Technogebied nam het aandeel werkzame personen met een technische opleiding dat buiten de eigen vakrichting werkzaam is in dezelfde periode toe met 3,8\%-punt tot bijna 39\%. Deze ontwikkeling kan deels verklaard worden uit de forse stijging in de werkgelegenheid in de niettechnische ICT-beroepen. Een hiermee samenhangende verklaring is de hoogconjunctuur en de krappe arbeidsmarkt in de jaren voor 2002, terwijl de werkgelegenheid in de technische beroepen nauwelijks groeide en in het Technogebied zelfs afnam. Dit betekent dat de krappe arbeidsmarkt in de niet-technische beroepen een sterke aanzuigende werking had op de technisch opgeleiden, waardoor zij steeds meer buiten hun eigen vakrichting zijn gaan werken.

Afgaande op de ontwikkelingen in de werkloosheid, de non-participatie en het aandeel dat werkzaam is buiten de eigen vakrichting, kan worden geconcludeerd dat de arbeidsmarktpositie van technisch opgeleiden in het Technogebied beter is dan in Nederland. Dat betekent ook dat de arbeidsmarkt voor technisch opgeleiden in het Technogebied krapper is dan voor Nederland als geheel. Dit blijkt overigens over het algemeen ook te gelden per opleidingsniveau (VMBO, MBO en HBO) ${ }^{31}$ Dat wil zeggen dat op elk niveau binnen de beroepskolom de arbeidsmarktpositie van technisch opgeleiden beter is en de arbeidsmarkt krapper is binnen het Technogebied vergeleken met Nederland als totaal.

Hierbij dient echter te worden aangetekend dat de werkloosheid en de nonparticipatie in het Technogebied voor àlle opgeleiden (technisch en niet-technisch) lager zijn dan in Nederland. De verschillen tussen het Technogebied en Nederland lijken echter kleiner te worden (werkloosheid en werk buiten eigen vakrichting) of klein te blijven (non-participatie) voor de technisch opgeleiden, terwijl de verschillen voor alle opgeleiden over de periode 1996-2002 juist even groot blijven (werkloosheid) of zelfs groter worden (non-participatie).

31. De vergelijking van de arbeidsmarktpositie tussen het Technogebied en Nederland per opleidingsniveau is niet weergegeven in deze paragraaf. In de volgende subparagraaf wordt uitsluitend de vergelijking tussen de technische opleidingen van het VMBO, MBO en HBO binnen het Technogebied weergegeven. 


\section{Arbeidsmarktpositie naar opleidingsniveau ${ }^{32}$}

In figuur 4.11 is de werkloosheid van technisch opgeleiden binnen het Technogebied uitgesplitst naar opleidingsniveau binnen de beroepskolom van het technisch onderwijs. De werkloosheid onder technisch opgeleiden van het VMBO is relatief hoog. De werkloosheid onder MBO'ers en HBO'ers (met uitzondering van 2002) met een technische opleidingsachtergrond is daarentegen verhoudingsgewijs laag. De werkloosheid onder technisch opgeleiden in het Technogebied is het laagst in 2000 (zie figuur 4.8). Vanaf dat jaar stijgt de werkloosheid, maar blijft deze voor MBO'ers in de technische richting lager dan die voor HBO'ers van dezelfde richting.

Figuur 4.11

Werkloosheid onder technisch opgeleiden in het Technogebied naar opleidingsniveau, als percentage van de totale beroepsbevolking, 1996-2002

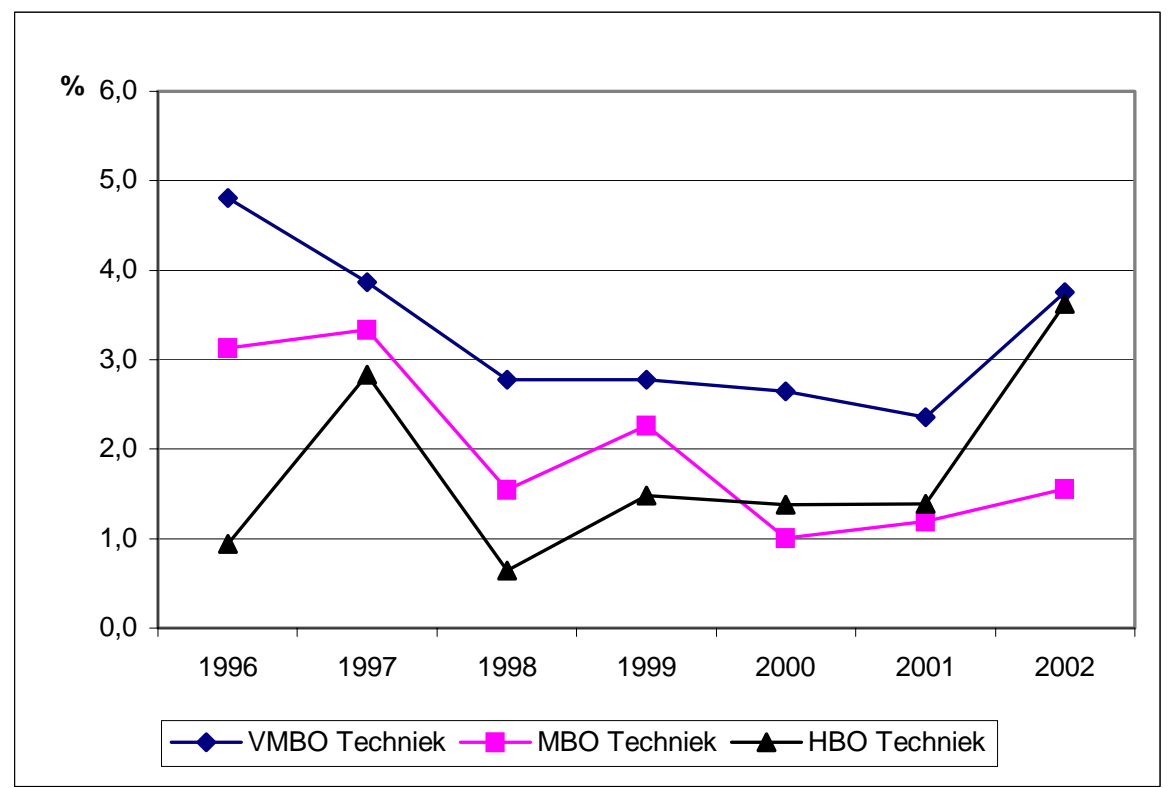

Bron: ROA/CBS

Eerder is al gebleken dat de non-participatie van technisch opgeleiden in het Technogebied is gedaald over de periode 1996-2002. Uit figuur 4.12 zien we deze trend het duidelijkst terug in het verloop van de non-participatie onder VMBO'ers. De non-participatie onder VMBO'ers is over het algemeen hoger dan die onder de middelbaar en hoger opgeleiden. Dit zien we ook terug voor de technische opleidingen. De non-participatie onder de HBO'ers met een technische opleiding is het laagst in 1999. In de laatste twee jaar is de non-participatie van MBO'ers met een technische opleiding lager dan die van HBO'ers van dezelfde richting.

32. In de onderstaande analyse moet rekening worden gehouden met uitschieters ten gevolge van steekproeffluctuaties. Deze fluctuaties zullen incidenteel niet de werkelijke ontwikkeling weergeven. 
In figuur 4.13 is het percentage werkzame personen met een technische opleiding die buiten de eigen vakrichting werken weergegeven voor de drie opleidingsniveaus. Uit de figuur volgt dat relatief veel HBO'ers met een technische opleiding in het Technogebied buiten hun eigen vakrichting werken. In 2002 werkt bijna 60\% van de HBO'ers met een technische opleiding buiten hun eigen vakrichting. MBO'ers met een technische opleiding werken het minst buiten hun eigen vakrichting. Op elk opleidingsniveau lijkt er een trend te zijn om vaker buiten de eigen vakrichting te werken.

In het vorige hoofdstuk is gebleken dat pas afgestudeerden van het MBO en HBO met een technische opleiding relatief weinig een baan buiten de eigen vakrichting krijgen. Ongeveer een kwart van de afgestudeerde MBO'ers en bijna een vijfde van de afgestudeerde HBO'ers in de technische richting vindt naar eigen zeggen een baan buiten de eigen vakrichting. Eerder is al gewezen op de verschillende methodiek om het werken buiten de vakrichting vast te stellen (subjectief versus objectief), en het verschil tussen pas afgestudeerden en de totale populatie van werkenden. Wat wel uit de vergelijking van deze gegevens kan worden geconcludeerd is dat HBO'ers aan het begin van hun carrière minder dan MBO'ers buiten hun eigen vakrichting werken, terwijl met het vorderen van de loopbaan HBO'ers meer dan MBO'ers in een niet-technisch beroep terecht komen.

Figuur 4.12

Non-participatie onder technisch opgeleiden in het Technogebied naar opleidingsniveau, als percentage van de totale potentiële beroepsbevolking, 1996-2002

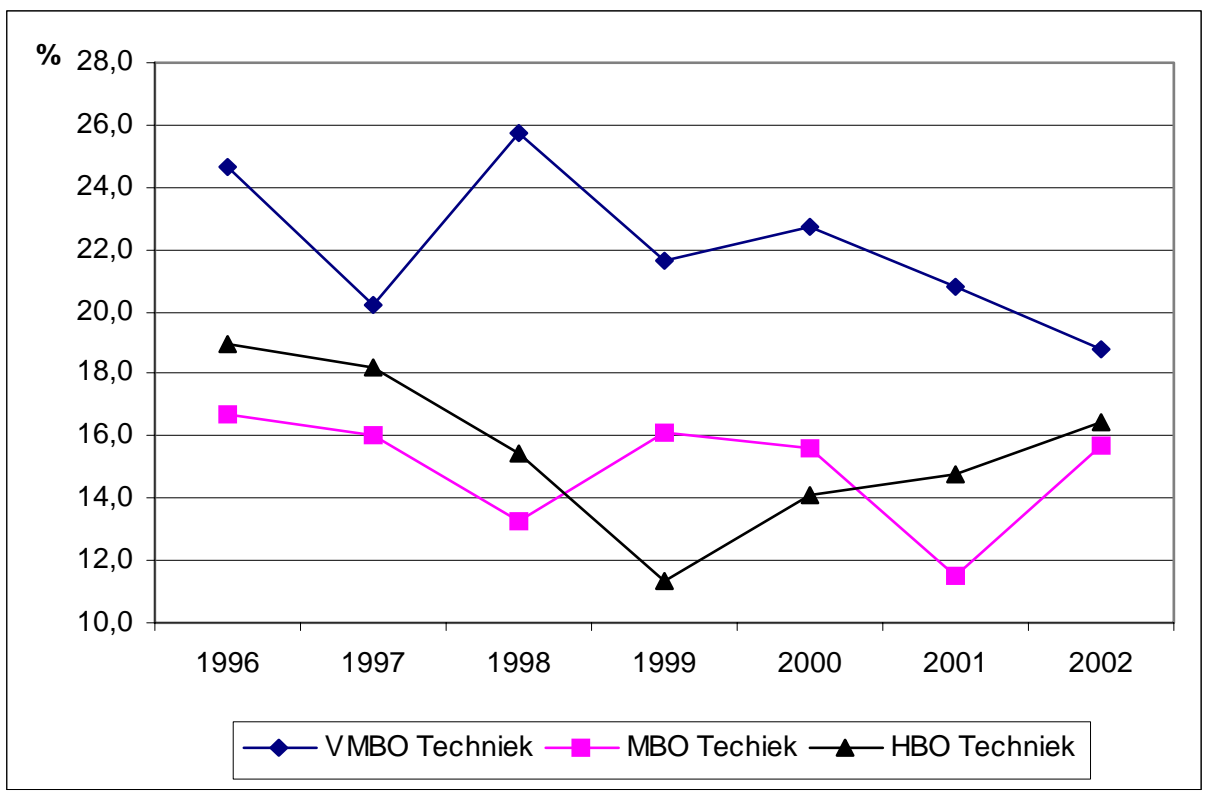

Bron: ROA/CBS 
Figuur 4.13

Technisch opgeleiden werkzaam buiten de eigen vakrichting naar opleidingsniveau, als percentage van de werkzame beroepsbevolking van technisch opgeleiden, 1996-2002

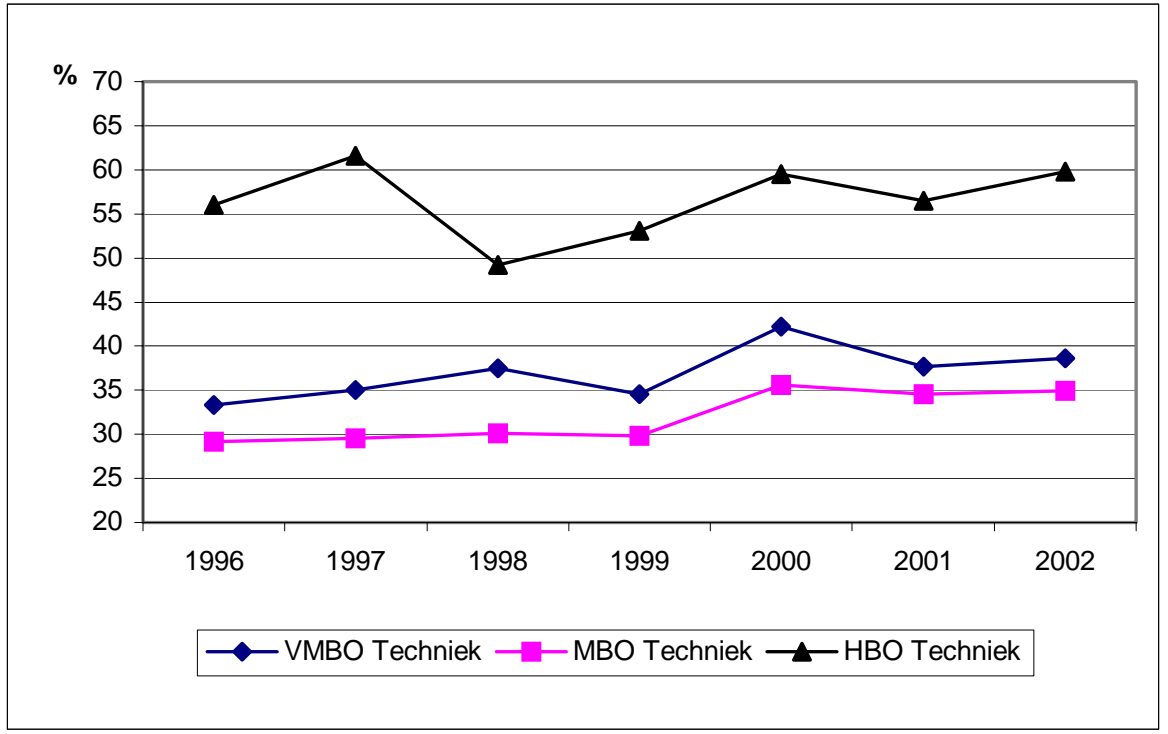

Bron: ROA/CBS

\subsection{Conclusies}

Werkgelegenheid in technische beroepen is relatief sterk gedaald in Technogebied

Er is gebleken dat de totale werkgelegenheid zich tussen 1996 en 2002 positief heeft ontwikkeld, zowel voor Nederland als voor het Technogebied. Hoewel de werkgelegenheidsgroei in het Technogebied ruim 4\%-punt lager was dan in Nederland, steeg de werkgelegenheid met $11 \%$. Ondanks deze hoge groeipercentages is de werkgelegenheid in de technische beroepen in het Technogebied gedaald, en nauwelijks gestegen in Nederland.

Het werkgelegenheidsaandeel van de technische beroepen in Nederland is tussen 1996 en 2002 gedaald van ongeveer 23\% tot 20\%. In het Technogebied is het werkgelegenheidsaandeel van de technische beroepen steeds hoger geweest dan in Nederland, maar hier is tevens de daling sterker. Tussen 1996 en 2002 is het percentage werkgelegenheid in de technische beroepen in het Technogebied gedaald van $27 \%$ naar $23 \%$.

Ook voor de aan de technische beroepen verwante wiskundige en natuurwetenschappelijke beroepen is de werkgelegenheid gedaald in het Technogebied en in Nederland. De werkgelegenheid in de niet-technische ICT-beroepen is daarentegen sterk gestegen. De afname van het werkgelegenheidsaandeel valt - evenals voor Nederland - ongeveer 1\%-punt lager uit als de aangrenzende wiskundige en natuurwetenschappelijke beroepen en niet-technische ICT beroepen worden meegenomen 
bij de technische beroepen. Dit komt doordat de afname bij de technische beroepen deels gecompenseerd wordt door de stijging van de niet-technische ICT-beroepen. De afname van het werkgelegenheidsaandeel van de technisch opgeleiden met 3\%punten voor het Technogebied en 2\%-punten voor Nederland komt zowel voor het Technogebied als voor Nederland overeen met de afname van het werkgelegenheidsaandeel van de technische beroepen 'in brede zin' (i.e. als de wiskundige en natuurwetenschappelijke beroepen en niet-technische ICT beroepen worden gerekend tot de technische beroepen).

\section{Arbeidsmarkt relatief krap in Technogebied}

Afgaande op de ontwikkelingen in de werkloosheid, de non-participatie en het aandeel dat werkzaam is buiten de eigen vakrichting, kan worden geconcludeerd dat de arbeidsmarktpositie van technisch opgeleiden in het Technogebied beter is dan in Nederland. Dat betekent ook dat de arbeidsmarkt voor technisch opgeleiden in het Technogebied krapper is dan voor Nederland als geheel. Dit blijkt overigens over het algemeen ook te gelden per opleidingsniveau (VMBO, MBO en HBO). Dat wil zeggen dat op elk niveau binnen de beroepskolom de arbeidsmarktpositie van technisch opgeleiden beter is en de arbeidsmarkt krapper is binnen het Technogebied vergeleken met Nederland als totaal.

Hierbij dient echter te worden aangetekend dat de werkloosheid en de nonparticipatie in het Technogebied voor àlle opgeleiden (technisch en niet-technisch) lager is dan in Nederland. De verschillen tussen het Technogebied en Nederland lijken echter kleiner te worden (werkloosheid en werk buiten eigen vakrichting) of klein te blijven (non-participatie) voor de technisch opgeleiden, terwijl de verschillen voor alle opgeleiden over de periode 1996-2002 juist even groot blijven (werkloosheid) of zelfs groter worden (non-participatie).

Arbeidsmarktpositie het best voor middelbaar technisch opgeleiden in het Technogebied

Vooral onder de technisch opgeleiden van het MBO in het Technogebied is de werkloosheid en de non-participatie laag. Bovendien werken zij weinig buiten hun eigen vakrichting, dat wil zeggen in een niet-technisch beroep. Binnen het Technogebied lijkt derhalve de arbeidsmarktpositie van MBO'ers met een technische opleiding het beste te zijn, gevolgd door die van de HBO'ers en de VMBO'ers. De keerzijde van de relatief goede arbeidsmarktpositie van technisch opgeleide MBO'ers in het Technogebied kan zijn dat werkgevers juist relatief moeite hebben om deze personen te rekruteren. Overigens kan het relatief grote aandeel HBO'ers dat buiten een technisch beroep terecht komt ook wijzen op hun brede inzetbaarheid op de arbeidsmarkt en de ontwikkeling van de loopbaan in managementfuncties waarvoor mogelijk toch een hogere technische opleiding gewenst is. 



\section{Overwegingen bij het sluiten of starten van een technische opleiding}

Uit de voorgaande hoofdstukken blijkt dat de belangstelling van jongeren voor het volgen van een bepaalde beroepsopleiding te verschuift van richtingen binnen techniek naar andere richtingen, zoals bijvoorbeeld verzorging. Deze ontwikkeling weerspiegelt deels de teruggang van de industrie als bron van werkgelegenheid naar allerlei vormen van dienstverlening. $\mathrm{Er}$ is echter meer aan de hand. De globalisering van de economie en het opkomende belang van kennis hierbij hebben ingrijpende gevolgen voor de techniek en organisatie van productieprocessen en daarmee voor de inhoud van de beroepen waarop de opleidingen zich richten. Naast een verschuiving van de beroepenstructuur van industrie naar diensten hebben we dus te maken met een versnelde vernieuwing van de inhoud van beroepen. Deze vernieuwing gaat gepaard met een vervaging van de grenzen tussen techniek en dienstverlening. Voor de adequate uitoefening van dienstverlenende beroepen is vaak een bepaalde mate van technische kennis vereist en voor industriële beroepen zijn ook communicatieve vaardigheden van belang en kan zelfs enige economischadministratieve kennis nodig zijn.

Bovengeschetste ontwikkelingen zijn moeilijk eenduidig te interpreteren naar de optimale verhouding tussen technische en niet-technische opleidingen binnen het beroepsonderwijs. Aan de ene kant lijkt de dalende belangstelling van leerlingen voor techniek te sporen met de structuurverschuiving van de economie in de richting van dienstverlening. Anderzijds zijn er veranderingsprocessen van techniek en organisatie in bedrijven die vragen om een vernieuwing van beroepsopleidingen zowel binnen als buiten techniek. In dit niet altijd even duidelijke spanningsveld tussen de opleidingsvoorkeuren van leerlingen en de eisen van de arbeidsmarkt moeten ROC's trachten hun opleidingenaanbod strategisch te positioneren. Zij hebben hierbij te maken met de beperkte mobiliteit van leerlingen en schoolverlaters waardoor de ROC's bij hun positionering van het opleidingenaanbod rekening moeten houden met de spreiding van zowel de bevolking als de werkgelegenheid over de ruimte. Bij beslissingen over het inhoudelijk vernieuwen, het afbouwen en het starten van opleidingen is dus steeds een ruimtelijke dimensie aan de orde. In dit hoofdstuk zullen we aan de hand van een tweetal cases, een sluiting en een opstart, aangeven welke overwegingen bij deze beslissingen in de praktijk een rol kunnen spelen.

De cases werden aangereikt vanuit de begeleidingscommissie van het onderzoek. Beide cases speelden zich af binnen het bestudeerde Technogebied. Elke case werd onderzocht door middel van een halfgestructureerd interview met een persoon die van alle ins en outs van de sluiting of opstart op de hoogte was. Het interview werd voorbereid door middel van het doornemen van een uitvoerige documentatie over het desbetreffende geval. Deze documentatie werd ons door de betrokken ROC's ter beschikking gesteld. 


\subsection{Het sluiten van een opleiding}

Het geval van sluiting betreft de laboratoriumopleidingen van Gilde Opleidingen te Venlo. Het gaat om opleidingen in technische, biologische, chemische en medische richtingen. De opleidingen zijn herkenbaar en heel traditioneel opgezet. Ze staan nogal op zichzelf en vertonen weinig verwantschap met andere opleidingen. De opleiding tot apothekersassistent komt nog het meeste in de buurt. De laboratoriumopleidingen worden, in aansluiting op CREBO, alleen langs de beroepsopleidende leerweg aangeboden. De opleidingen betreffen uitsluitend niveau 4. Van oudsher hadden de opleidingen een hele goede naam. Sinds de fusievorming in het middelbaar beroepsonderwijs is er echter weinig veranderd. Nog steeds dezelfde docenten, hetzelfde gebouw en dezelfde manier van onderwijs geven.

De opleidingen betrekken hun leerlingen niet alleen uit de directe omgeving. Het zijn vaak gemotiveerde leerlingen die aan deze opleidingen deelnemen. Afstand is voor hen geen probleem. De opleidingen kennen een relatief hoge doorstroom naar de HBO opleiding laboratoriumtechniek (HLO). De leerlingen staan bekend als erg goede leerlingen. In samenhang met de dalende belangstelling voor technische opleidingen kregen de opleidingen te kampen met dalende leerlingaantallen. Een niveau werd bereikt van zo'n 40 leerlingen, ver beneden het niveau waarbij de kosten worden goedgemaakt. Een probleem dat trouwens veel technische opleidingen treft. Extra wervingscampagnes en voorlichtingsactiviteiten leverden niet meer leerlingen op voor de kwakkelende laboratoriumopleidingen.

De plannen voor samenvoeging van alle technische opleidingen in Venlo in een nieuw modern gebouw (Technodôme) vormden de aanleiding om de laboratoriumopleidingen te beëindigen. Invoeging in het nieuwe gebouw zou een aanzienlijke nieuwe investering in de opleidingen hebben gevergd met uiterst twijfelachtig rendement. Besloten is de opleidingen vanaf augustus 2004 af te bouwen.

Er zijn nog verschillende opties bekeken om de opleidingen open te houden. Getracht werd de gemeente Venlo financieel te interesseren. Dit stuitte af op de geringe herkomst van de leerlingen uit Venlo zelf. Een andere mogelijkheid is om verwante technische opleidingen te concentreren op één vestigingsplaats. Dit geeft schaalvoordelen en meer mogelijkheden voor herstructurering en vernieuwing van opleidingen. Zoals gezegd staan de laboratoriumopleidingen nogal op zichzelf waardoor geen synergie met andere opleidingen te verwachten is. Concentratie van technische opleidingen is overigens niet zonder gevaren. Bij opleidingen die hun leerlingen betrekken uit de naaste omgeving kan verandering van vestigingsplaats van de opleiding tot verminderde deelname leiden. Dit probleem geldt in het bijzonder voor Gilde Opleidingen dat een uitgestrekt voedingsgebied heeft met een relatief geringe bevolkingsconcentratie. Anders ligt de situatie voor een ROC dat een grote stad tot zijn voedingsgebied kan rekenen, zoals bijvoorbeeld ROC Eindhoven (zie verder hoofdstuk 6).

Onderzoek laat zien dat er op nationaal niveau een nijpend tekort is aan MBO'ers met een laboratoriumopleiding. Er werden echter geen signalen afgegeven vanuit het 
bedrijfsleven dat men de school wilde steunen bij het overeind houden van de opleidingen. Hier kunnen verschillende redenen voor zijn. Men denkt gemakkelijk de nodige schoolverlaters met een laboratoriumopleiding te kunnen werven die afkomstig zijn van andere ROC's. Ook kan het zijn dat de desbetreffende werkgevers niet in staat zijn dergelijke signalen af te geven omdat het middelgrote en kleine bedrijven betreft die niet tot samenwerking kunnen komen. Verder is er met deze bedrijven geen bestaande band aanwezig, waarlangs eventuele samenwerking zou kunnen worden geïnitieerd, door het ontbreken van een stelsel van leerlingplaatsen. Het betreft immers opleidingen volgens de beroepsopleidende leerweg.

\subsection{Het starten van een opleiding}

De oprichtingscase betreft het schildersvakcentrum te Nuenen. Dit initiatief is ontstaan uit de onvrede van werkgevers uit de regio met het verdwijnen van steeds meer schildersopleidingen uit het opleidingenaanbod van scholen. De opleiding verdween uit het VMBO (toen nog LTS) en was aanvankelijk binnen het MBO alleen aanwezig als korte opleiding volgens de beroepsbegeleidende leerweg (KMBO). Pas veel later kwamen er ook niveau 2 en 3 opleidingen, eerst in Helmond en later in Eindhoven. De onvrede met het verdwijnen van de schildersopleidingen leidde tot de oprichting van een samenwerkingsverband van werkgevers (de latere SPOS). Zeven jaar geleden kwam het samenwerkingsverband met het idee voor de oprichting van een schildersvakcentrum. In de schildersbranche gaat het vaak om kleine familiebedrijven, die in toenemende mate ook personeel in dienst hebben. Zij zouden zich via het vakcentrum kunnen verzekeren van voldoende toestroom van jonge medewerkers en zouden ook hun eigen kinderen naar een specifieke schildersopleiding kunnen sturen. Het duurde toch nog enige tijd alvorens de plannen gerealiseerd konden worden. Verschillende partijen zagen het vakcentrum aanvankelijk als een bedreiging, met name het vakcentrum van de eigen branche. Het ROC Ter AA en het ROC Eindhoven, waarmee al langer werd samengewerkt, bleken bereid deel te nemen aan het op te richten schildersvakcentrum. Voor hen zou deze samenwerking uitzicht kunnen bieden op continuïteit en stabiele leerlingenaantallen van voldoende omvang.

Het vakcentrum is nu operationeel. Er worden opleidingen aangeboden op de niveaus 1, 2 en 3, allen volgens de beroepsbegeleidende leerweg. Daarnaast is er een 22+ traject en zijn er aanvullende scholingen en trainingen in samenwerking met Savantis, de branche-organisatie voor schildersvakopleidingen. De beide deelnemende ROC's zullen hun schildersvakopleidingen in Helmond en Eindhoven volledig afbouwen. Alles zal in Nuenen worden aangeboden. De leerlingen van de reguliere opleidingen werken vier dagen per week bij een (schilders)bedrijf en gaan een dag per week naar school. Het vakcentrum organiseert per jaar twee terugkomweken. De mogelijkheden voor opleidingen volgens de beroepsopleidende leerweg worden nog onderzocht. Men zou dan ook kunnen opleiden voor middenkaderfuncties. Het centrum wil voorzien in een behoefte van zo'n 90, na de 'babyboom' dalend tot 60 , vaklieden per jaar. Het aantal leerlingen is groeiend en ligt nu op 127. 
Als vestigingsplaats werd bewust gekozen voor Nuenen, midden in het eigen voedingsgebied, zodat zo weinig mogelijk leerlingen vanwege de afstand naar school verloren gaan aan andere opleidingen. De ruimtelijke dimensie heeft dus bij de vestigingsplaatskeuze expliciet als strategische factor een rol gespeeld. Het gemeenschappelijke belang van bedrijven en scholen bij het schildersvakcentrum heeft ook geleid tot een gezamenlijke financiële betrokkenheid. De betrokken bedrijven hebben het gebouw voorgefinancierd en de overheid draagt bij in de kosten van het centrum, via de deelnemende ROC's, op basis van de leerlingaantallen en het aantal behaalde diploma's. Het bedrijfsleven is hier de belangrijkste risicodrager. De aangeboden opleidingen zijn overigens meer dan kostendekkend.

Er wordt bij het centrum heel bedrijfsmatig gedacht en gewerkt. De bedrijven zorgen voor een gegarandeerde werkgelegenheid voor een periode van twee tot vier jaar bij het behalen van het diploma. Daarnaast is er een commissie werving en selectie actief met een jaarprogramma. VMBO scholen komen met groepen leerlingen op bezoek en er worden allerlei promotionele activiteiten ondernomen, bijvoorbeeld op beroepsdagen in het VO. Jongeren die belangstelling hebben voor de opleiding worden getest op kleurenblindheid, hoogtevrees en motorisch disfunctioneren. Ook wordt naar hun motieven om de opleiding te volgen gevraagd. Het krijgen van een baangarantie is hierbij een onvoldoende motief.

De schildersvakopleidingen horen wel tot de categorie technische opleidingen maar de exacte vakken zijn er minder belangrijk. Het accent ligt op het aanbrengen van praktische intelligentie en communicatieve vaardigheden. De koppeling tussen theorie en praktijk is heel belangrijk.

Het schildersvakcentrum te Nuenen wil een voorbeeld zijn op landelijk niveau van hoe de samenwerking tussen werkgevers en onderwijsinstellingen zou kunnen zijn en wat het zou kunnen opleveren. Gewezen wordt op het belang om vooraf marktonderzoek te doen en de technische, commerciële en economische haalbaarheid goed te onderzoeken. Als de haalbaarheid is aangetoond, maak dan een bedrijfsplan. Echter, zonder voldoende ondernemingsgeest van betrokken partijen zal er niets van de grond komen, zo wordt gesteld.

Men wil het vakcentrum verder uitbouwen als kennis- en opleidingscentrum. Men zoekt naar mogelijkheden, zoals al gezegd, voor de beroepsopleidende leerweg, maar ook voor het VMBO en het HBO. Het gaat bij het schildersbedrijf niet meer om alleen schilderen maar om allerlei vormen van afwerkingstechnieken (met nieuwe technologieën zoals 'spray \& go' en 'laser'). Er is een ontwikkeling naar onderhoud in brede zin. Het centrum zou een rol kunnen spelen ten aanzien van de kennisontwikkeling op dit vlak. Dit is echter vooralsnog een verder weg liggend perspectief. 


\subsection{Conclusies}

Uit de hier besproken cases komen enkele interessante conclusies naar voren. Twee cases zijn natuurlijk onvoldoende om een en ander hard te maken. Het volgende moet daarom vooral als indicatief worden gezien.

\section{Betrokkenheid van bedrijfsleven van belang bij bepalen van opleidingenaanbod}

Bij het vraagstuk van starten of sluiten van een opleiding is het belangrijk dat alle betrokken partijen zich als mede-eigenaar van het probleem zien en bereid zijn in een oplossing te investeren. Als het bedrijfsleven niet betrokken raakt, blijt een sluitingsprobleem al gauw een afweging waarin het louter gaat om al of niet voldoende leerlingenaantallen en wel of niet dragelijke kosten. De eventuele schade aan de kant van de arbeidsmarkt blijft dan buiten beeld en wordt niet meegewogen. Ook worden de risico's van eventuele vernieuwing al gauw als onverantwoord ingeschat.

Daadwerkelijke betrokkenheid van het bedrijfsleven, inclusief deelname aan de financiële risico's, kan nieuwe perspectieven openen. Het vormt in de eerste plaats een signaal dat er een behoefte ligt op de arbeidsmarkt, zodat er in principe rendabel in een opleiding kan worden geïnvesteerd. Daarnaast ontstaat een cultuur van ondernemen en een bedrijfsmatige kijk op de te nemen investeringsbeslissingen. Hierdoor wordt een klimaat geschapen voor creatieve oplossingen die het rendement van deze beslissingen vergroten. Zo kan aan de outputkant een optimale benutting plaatsvinden van de geschapen opleidingsvoorzieningen in de vorm van allerlei scholingsactiviteiten in het initiële en post-initiële traject en van activiteiten met het karakter van onderzoek. Aan de inputkant kan een marketingbenadering worden gevolgd die alle facetten van de keuzes van leerlingen die nog in de aanvoerlijnen van de opleidingen zitten systematisch 'bespelen'.

\section{Afweging tussen voor- en nadelen bij ruimtelijke concentratie van opleidingen}

Samenbundeling en ruimtelijke concentratie van verwante opleidingen geven voordelen van schaal en synergie. Het opleidingsproces kan dan efficiënter worden georganiseerd door intensiever gebruik van leraren en materieel. De drempels voor vernieuwing van opleidingen via processen van afbouw, opstarten en herstructurering worden lager: meer perspectief en minder pijn.

Niet alle ROC's hebben hier dezelfde mogelijkheden. De beperkte mobiliteit van leerlingen van het MBO geeft ROC's in of nabij grote bevolkingsconcentraties een voordeel ten opzichte van ROC's die in 'buitengebieden' opereren. Een te grote concentratie van verwante opleidingen in het buitengebied leidt tot een uitwijk van de verder weg wonende leerlingen naar andere opleidingen die gemakkelijker bereikbaar zijn. Dit betekent dat dergelijke ROC's bij verdere concentratie van opleidingen eerder met een scherpe afweging worden geconfronteerd tussen enerzijds de voordelen van meer synergie en een grotere locale schaal en anderzijds de dalende belangstelling van leerlingen voor het desbetreffende opleidingencluster door de grotere reisafstand. 



\section{De keuze voor techniek}

Uit de voorgaande hoofdstukken is gebleken dat de populariteit van een technische beroepsopleiding ten opzichte van andere beroepsopleidingen is gedaald in de loop der tijd, ondanks dat de arbeidsmarktperspectieven voor technisch geschoolden overwegend goed zijn (ROA, 2003). In dit hoofdstuk wordt de studiekeuze van leerlingen nader onderzocht, waarbij wordt gekeken naar de verschillen in achtergrondkenmerken tussen eerstejaarsleerlingen van het MBO die voor techniek en niet voor techniek hebben gekozen. De achtergrondkenmerken hebben onder meer betrekking op geslacht, leeftijd, vooropleiding, herkomst, kenmerken van de ouders. Er wordt tevens nagegaan welk belang leerlingen bij hun studiekeuze hechten aan de opleiding en het beroep dat men met de opleiding kan uitoefenen, aan de school en de omgeving van de school, en aan de reisafstand en -tijd bij de studiekeuze.

De keuze van leerlingen voor een vervolgopleiding na het voortgezet onderwijs wordt bepaald door hun preferenties. Het gaat daarbij om de waarde die een leerling toekent aan verschillende aspecten die met de keuze voor een bepaalde opleiding gepaard gaan. Het gaat er bijvoorbeeld om hoe leuk of interessant een opleiding wordt gevonden, welk beroep men met de opleiding kan uitoefenen, welk inkomen daarmee gepaard gaat, wat de kans op werk is, wat de carrièreperspectieven zijn, welke status het beroep heeft, etc. Ook als vrienden en vriendinnen van de leerling voor een bepaalde opleiding kiezen of in de familie- of kennissenkring een opleidings- of beroepsachtergrond domineert kan dit bijdragen aan een hogere (en soms ook lagere) waardering voor een opleiding of beroep.

Daarnaast kunnen ook restricties bij de opleidingskeuze een rol spelen, zoals de moeilijkheidsgraad van een opleiding, de studiekosten en de afstand tot de opleidingslocatie. Deze restricties vertegenwoordigen een negatieve waarde bij de opleidingskeuze. Volgens de economische theorie kent een leerling (impliciet) aan elk van de genoemde aspecten een positieve of negatieve waarde toe bij de opleidingskeuze (zie bijv. Borghans, 1999 en Borghans en De Steur, 1999). De studiekeuze is in de economische theorie dus een rationeel proces, waarbij ook het vermogen van leerlingen om zich een beeld te vormen van de toekomstige situatie en de consequenties van de keuze voor een opleiding een rol speelt. ${ }^{33}$ De opleiding die voor een bepaalde leerling het grootste positieve verschil genereert tussen verwachte kosten en baten wordt door de leerling gekozen.

Uit onderzoek door Bloemen en Dellaert (2000) blijkt dat leerlingen in het voortgezet onderwijs (VMBO en HAVO/VWO) zich vooral laten leiden door hoe interessant ze een opleiding vinden, en in welke mate ze in het beroep dat met de opleiding wordt geassocieerd iets voor andere mensen of voor de maatschappij kunnen betekenen. De kosten van het volgen van een bepaalde opleiding spelen nauwelijks een rol. Het

33. Daarbij ligt de relatie met de percepties van de leerlingen voor de hand. Hier ligt in de psychologische literatuur de nadruk op. Vooral bij gebrek aan volledige informatie spelen beeldvorming en imago een rol in het keuzeproces. 
verwachte loon en de kans op werk zijn relatief belangrijk voor mannen en voor leerlingen die kiezen voor economie en informatica. Een groter loonverschil of een groter verschil in de arbeidsmarktsituatie tussen twee opleidingen kan echter slechts in beperkte mate de keuze tussen deze opleidingen veranderen. Vrouwen en leerlingen die kiezen voor de zorg of het onderwijs waarderen juist het helpen van andere mensen en de bijdrage aan de maatschappij relatief hoog. In het kader van het voorliggende onderzoek is vooral van belang dat zij concluderen dat een reisafstand tot $30 \mathrm{~km}$. van thuis naar school nauwelijks invloed heeft op de studiekeuze. Bij een reisafstand van $80 \mathrm{~km}$. of langer is deze invloed wel significant aanwezig. Voor de tussenliggende afstanden is er niet getoetst hoe groot de invloed is.

Het onderzoek van Bloemen en Dellaert (2000) is gebaseerd op zogenaamde 'stated preferences'. Dit zijn door individuen aangegeven voorkeuren als een situatie zich zou voordoen. Het gaat dus niet om de feitelijke keuze van individuen, maar om de keuze die men aangeeft in een beperkt aantal, vaak hypothetische situaties, te zullen maken. Dit in tegenstelling tot de 'revealed preferences' waarin de feitelijk gemaakte keuzes centraal staan. Deze hebben in dit rapport betrekking op de werkelijke opleidingskeuze en de werkelijke afstand die leerlingen reizen van thuis naar school.

Voor de analyse in dit hoofdstuk is gebruik gemaakt van beide methodes. Ten eerste is er een databestand gegenereerd op basis van de gegevens uit de leerlingenadministratie van vijf grote ROC's in het Technogebied (Gilde Opleidingen, ROC Eindhoven, ROC Ter Aa, ROC De Leijgraaf en Koning Willem I College). Het betreft daarbij alleen de nieuwe instroom van (eerstejaars) leerlingen in het reguliere onderwijs (geen volwasseneducatie, geen contractonderwijs) op deze ROC's. De gegevens van deze leerlingen hebben betrekking op een beperkt aantal gegevens zoals deze voorkomen in of af te leiden zijn uit de leerlingenadministratie van de ROC's, waaronder geslacht, leeftijd, herkomst, vooropleiding, onderwijsachterstand, opleiding, opleidingslocatie en woonadres. Het totale bestand heeft betrekking op 15.761 leerlingen die in het voorjaar van 2005 stonden ingeschreven bij één van de vijf genoemde ROC's.

Van alle in Nederland wonende leerlingen is met behulp van een routeplanner de kortste afstand bepaald tussen de postcodes van het woonadres en de opleidingslocatie. Aan de hand van het databestand wordt inzicht gegeven in de reisafstand naar school van een zeer groot deel van de eerstejaars MBO-leerlingen die wonen in het Technogebied, en van een deel van de leerlingen die in de aangrenzende regio's wonen maar in het Technogebied naar school gaan. Hiermee wordt tevens inzicht gegeven in de reikwijdte en het 'voedingsgebied' van de ROC's, en de eerder genoemde 'revealed preferences' ten aanzien van de reisafstand die leerlingen bereid zijn te overbruggen.

Ten tweede is een beperkt aantal eerstejaars leerlingen van vier ROC's in het Technogebied geënquêteerd, namelijk van Gilde Opleidingen, ROC Eindhoven, ROC De Leijgraaf en Koning Willem I College. De enquête is uitgevoerd met behulp van de ROC Spiegel (zie www.rocspiegel.nl). Op basis van de respons van de leerlingen is er een koppeling gemaakt met een selectie van leerlingen uit de leerlingen- 
administratie (3.886 leerlingen, zie Bijlage 7) om door middel van weging te kunnen corrigeren voor selectiviteit. Verder dient de leerlingenenquête vooral ter aanvulling op de gegevens over de achtergrondvariabelen in de bestanden van de leerlingenadministratie. Veel gegevens over leerlingen zijn immers bekend uit de leerlingenadministratie (geslacht, leeftijd, herkomst, opleidingen, etc). De enquêtegegevens hebben betrekking op aanvullende achtergrondkenmerken als vooropleiding en gegevens over de ouders. Daarnaast is de enquête bedoeld om een indicatie te geven van de motieven bij de studiekeuze en de relatie met de reisafstand. Dit gebeurt door de eerder genoemde 'stated preferences', te achterhalen. Dat betekent dat aan leerlingen bijvoorbeeld is gevraagd of zij hun opleidingskeuze zouden veranderen als ze voor het volgen van een alternatieve opleiding veel minder ver hoeven te reizen dan voor de opleiding van de eerste keuze.

De analyse in dit hoofdstuk heeft tot doel antwoord te krijgen op de vraag of leerlingen die in potentie geïnteresseerd zijn in een technische opleiding niet voor een technische opleiding kiezen omdat ze de afstand tot de school waar ze deze opleiding kunnen volgen te groot vinden. We willen weten in welke mate leerlingen daardoor niet kiezen voor een technische opleiding maar voor een niet-technische opleiding op een school die dichterbij ligt. Om antwoord te krijgen op deze vraag worden analyses uitgevoerd met betrekking tot de volgende deelvragen:

(1) Hoe groot is het aandeel leerlingen dat kiest voor een opleiding techniek in de verschillende regio's in en rondom het Technogebied?

(2) Wat is de relatie tussen dat aandeel en de spreiding van de opleidingslocaties van de vijf eerder genoemde ROC's in het Technogebied voor de sector techniek ten opzichte van de andere sectoren economie en zorg?

(3) Hoe groot is de reisafstand van leerlingen techniek, economie en zorg tot de verschillende opleidingslocaties in het Technogebied?

(4) Hoe groot is de invloed van de reisafstand en reistijd op de opleidingskeuze ten opzichte van andere factoren zoals achtergrondkenmerken van de leerlingen en de ouders van de leerlingen, interesse voor de opleiding of het vak, schoolkenmerken en kenmerken van de omgeving van de school?

In de volgende paragraaf wordt eerst gekeken naar de verdeling van leerlingen van de vijf ROC's over de sectoren techniek, economie en zorg per 2-cijferig postcodegebied. Daarbij wordt tevens aangegeven of er in het postcodegebied waar de leerlingen wonen een opleiding techniek, zorg of economie wordt aangeboden door één of meerdere van de vijf ROC's. In paragraaf 6.2 wordt nader ingegaan op de achtergrondkenmerken van de leerlingen techniek, economie en zorg, in het bijzonder op de reisafstand naar school. Hierbij wordt ook ingegaan op de verschillen tussen de ROC's. In paragraaf 6.3 volgt een beschrijving van de resultaten van de leerlingenenquête. Deze resultaten hebben betrekking op zowel de achtergrondkenmerken van leerlingen en hun ouders als de eerder genoemde 'stated preferences'. In paragraaf 6.4 volgen de conclusies. 


\subsection{Deelname aan techniek, economie en zorg per postcodegebied}

Tabel 6.1 geeft het aandeel leerlingen techniek, economie en zorg weer naar postcodegebied van de woonplaats van de leerlingen. Het betreft eerstejaars leerlingen die nieuw in een opleiding (evt. aan dezelfde ROC) zijn ingestroomd. De leerlingen stonden in het voorjaar van 2005 (schooljaar 2004/2005) geregistreerd bij één van de vijf ROC's (excl. contractonderwijs en volwasseneducatie). ${ }^{34}$ Van de vijf ROC's gezamenlijk heeft $27 \%$ van de leerlingen voor techniek gekozen, $41 \%$ voor economie en $32 \%$ voor zorg.

In tabel 6.1 is tevens weergegeven of er een opleidingslocatie van de drie onderscheiden opleidingsrichtingen in het betreffende gebied aanwezig is. Bij de vaststelling of er in een postcodegebied een opleidingslocatie is voor techniek, economie of zorg, is alleen gekeken naar de hoofd- en nevenvestigingen van de vijf bij het onderzoek betrokken ROC's. Als het opleidingenaanbod van andere ROC's en van opleidingsbedrijven en vakscholen (BBL) wordt betrokken in de tabel dan worden er in alle hier onderscheiden postcodegebieden technische opleidingen aangeboden. Hierbij is echter van belang op te merken dat het aanbod van technische opleidingen beperkt is als er geen hoofd- of nevenvestiging van één de vijf grote ROC's is in deze gebieden (zie hoofdstuk 2). ${ }^{35}$

Het valt op dat de leerlingen die een opleiding volgen op één van de vijf ROC's en van buiten het Technogebied afkomstig zijn, vaker voor een technische opleiding kiezen. Van de leerlingen woonachtig in Sittard e.o. - en geregistreerd bij één van de vijf ROC's - kiest 32\% voor een technische opleiding binnen het Technogebied. In de omgeving Waalwijk is dit eveneens $32 \%$ en in de omgeving Tilburg zelfs $35 \%$. Ook in de buitengebieden $^{36}$ woont een bovengemiddeld groot aandeel van de nieuwe leerlingen (31\%) dat voor techniek kiest. Consequentie hiervan is dat de aandelen in economie en zorg van leerlingen die woonachtig zijn in deze gebieden meestal onder het gemiddelde aandeel van alle ROC's ligt. Belangrijkste uitzondering hierop is het aandeel zorg van de leerlingen die woonachtig zijn in Sittard e.o. Dat hoge aandeel kan verklaard worden doordat het onderzoek zich hier uitsluitend op Gilde Opleidingen richt, welke instelling in Sittard-Geleen uitstuitend zorgopleidingen aanbiedt.

Ook voor techniek zou dus het aanbod van opleidingen in een postcodegebied een rol kunnen spelen voor de opleidingskeuze van leerlingen die in dat gebied wonen. Dat lijkt echter niet waarschijnlijk gezien het relatief grote aandeel leerlingen dat voor techniek kiest maar woonachtig is in een gebied waar geen technische opleiding wordt aangeboden door één van de vijf ROC's. Het aantal gebieden waar geen

34. Zie Bijlage 7 voor de methodologie van de selectie en de koppeling van leerlinggegevens van de vijf ROC's.

35. Zie ook Bijlage 3. Zie Bijlage 8 voor het aandeel leerlingen techniek per opleidingslocatie van de vijf ROC's

36. Dit zijn alle 2-cijferige postcodegebieden kleiner dan 50 en groter dan 61 waar relatief weinig leerlingen woonachtig zijn die bij één van de vijf ROC een opleiding volgen. Overigens valt ook het grootste gedeelte van de postcodegebieden 50, 51 en 61 buiten de formele grenzen van het Technogebied Zuidoost-Nederland. Van enkele leerlingen is de postcode niet bekend. 
technische opleidingen door de vijf ROC's wordt aangeboden, is bovendien nauwelijks kleiner dan voor de economie- en zorgopleidingen (respectievelijk 1 en 2 gebieden). Verder valt het op dat in de gebieden waar technische opleidingen moeten concurreren met de economie- en zorgopleidingen het aandeel techniek vaak juist kleiner is dan gemiddeld. Uitzonderingen hierop zijn de gebieden rondom Oss en Veghel.

Tabel 6.1

Aandeel eerstejaars leerlingen techniek, economie en zorg naar postcodegebied van hun woonplaats, voorjaar 2005

\begin{tabular}{|c|c|c|c|c|c|c|c|c|}
\hline \multirow{2}{*}{\multicolumn{2}{|c|}{$\begin{array}{l}\text { Postcodegebied } \\
\text { (2 - ciiferig) van woon- } \\
\text { plaats van leerlingen }\end{array}$}} & \multirow{2}{*}{$\begin{array}{r}\text { Eerstejaars } \\
\text { leerlingen } \\
\text { aantal } \\
(=100 \%)\end{array}$} & \multicolumn{2}{|c|}{ Techniek } & \multicolumn{2}{|c|}{ Economie } & \multicolumn{2}{|c|}{ Zorg } \\
\hline & & & $\begin{array}{r}\text { aandeel } \\
\%\end{array}$ & locatie* & $\begin{array}{r}\text { aandeel } \\
\%\end{array}$ & locatie* & $\begin{array}{c}\text { aandeel } \\
\%\end{array}$ & locatie* \\
\hline 50 & Tilburg, Hilvaren-beek & 243 & 35 & nee & 33 & nee & 32 & nee \\
\hline 51 & Waalwijk, Dongen & 273 & 32 & nee & 40 & nee & 28 & nee \\
\hline 52 & Den Bosch, Vught & 1.277 & 26 & ja & 42 & ja & 33 & ja \\
\hline 53 & Oss, Zaltbommel & 1.854 & 33 & ja & 39 & ja & 28 & ja \\
\hline 54 & Veghel, Cuijk, Uden & 2.529 & 28 & ja & 38 & ja & 34 & ja \\
\hline 55 & Valkenswaard, Veldhoven & 665 & 32 & nee & 36 & nee & 32 & nee \\
\hline 56 & Eindhoven, Nuenen, Best & 1.308 & 24 & ja & 45 & ja & 31 & ja \\
\hline 57 & Helmond, Deurne & 1.448 & 24 & ja & 41 & ja & 35 & ja \\
\hline 58 & Venray, Boxmeer & 743 & 25 & nee & 42 & ja & 33 & ja \\
\hline 59 & Venlo & 2.002 & 24 & ja & 42 & ja & 34 & ja \\
\hline 60 & Roermond, Weert & 1.935 & 25 & ja & 46 & ja & 30 & ja \\
\hline 61 & Echt, Sittard, Geleen & 390 & 32 & nee & 27 & nee & 40 & ja \\
\hline \multicolumn{2}{|c|}{ Totaal 50-61 } & 14.667 & 27 & & 41 & & 32 & \\
\hline \multicolumn{2}{|c|}{ Totaal buitengebieden } & 1.084 & 31 & nee & 46 & nee & 23 & nee \\
\hline \multicolumn{2}{|c|}{$\begin{array}{l}\text { Totaal ROC's } \\
\text { Technogebied }\end{array}$} & 15.751 & 27 & & 41 & & 32 & \\
\hline
\end{tabular}

* Opm.: Zie voetnoten.

Bron: ROA / ROC Ter AA / Gilde Opleidingen / ROC Eindhoven / Koning Willem I College / ROC De Leijgraaf

Leerlingen die kiezen voor een technische opleiding overbruggen dus een grotere afstand naar school dan andere leerlingen. Er lijken daarbij andere factoren een rol te spelen dan de spreiding van het opleidingenaanbod. Niettemin zou een extra opleidingslocatie met uitsluitend technische opleidingen in het Technogebied wel extra leerlingen voor een techniekopleiding kunnen winnen ten koste van de andere richtingen. Tabel 6.1 laat echter ook zien dat als techniekopleidingen met economieen zorgopleidingen op dezelfde opleidingslocatie of binnen een relatief klein gebied concurreren om de gunst van de leerling, zij in het nadeel lijken te zijn. 
Er zijn ook andere verklaringen voor het relatief grote aandeel leerlingen dat op grotere afstand van een opleidingslocatie woont en voor techniek kiest. Zo zouden leerlingen met interesse voor techniek meer gemotiveerd kunnen zijn om te doen wat ze leuk vinden, en een grotere reisafstand voor lief willen nemen. Daarnaast zijn er relatief veel mannelijke leerlingen die interesse hebben in techniek. Mannen zijn over het algemeen meer bereid om over langere afstand te reizen dan vrouwen. Verder biedt ook het relatief grote aandeel BBL'ers een verklaring. BBL'ers hoeven slechts één dag per week naar school waardoor een grotere reisafstand naar school minder zwaar weegt. Tot slot is het mogelijk dat in gebieden met grotere bevolkingsconcentraties de dienstensectoren in plaats van de industrie belangrijker zijn, waardoor leerlingen eerder geneigd zouden kunnen zijn om te kiezen voor een opleiding die aansluit bij de werkgelegenheid in hun directe omgeving. In het vervolg van dit hoofdstuk wordt gekeken naar deze en andere mogelijke verklaringen voor de relatief grote spreiding van leerlingen die voor techniek kiezen.

\subsection{Achtergrondkenmerken van leerlingen en leerlingenpopulatie per ROC}

Om beter zicht te krijgen op de verklarende factoren voor de spreiding van leerlingen binnen het Technogebied naar opleidingsrichting, worden in deze paragraaf de achtergrondkenmerken van de 15.761 leerlingen van de vijf ROC's beschreven. Vervolgens wordt gekeken naar de populatie van eerstejaars leerlingen per ROC. Hierbij gelden voor het gebruikte databestand dezelfde kanttekening als die bij tabel 6.1 van de vorige paragraaf zijn gemaakt.

In tabel 6.2 is een aantal kenmerken van leerlingen weergegeven per opleidingsrichting. Deze kenmerken betreffen het gemiddelde en de mediaan van de afstand naar school en de leeftijd van de leerlingen, en het aandeel leerlingen dat kiest voor een technische, economische of zorgopleiding. Dit aandeel dient te worden vergeleken met het totale aandeel van één van de drie sectoren onderaan de tabel. Uit de mediaan en het gemiddelde van de afstand blijkt dat er relatief veel techniekleerlingen zijn die een grote afstand naar school afleggen, terwijl er een relatief kleine groep economieleerlingen is die een grote afstand naar school aflegt (zie ook de standaard deviatie in Bijlage 9). Van alle mannen in de steekproef kiest iets minder dan de helft voor een technische opleiding, terwijl nog geen $4 \%$ van de vrouwen dit doet. In de zorg is dit omgedraaid: bijna 60\% van alle vrouwen kiest voor een zorgopleiding, tegenover slechts $8 \%$ van de mannen. Mannen zijn dus oververtegenwoordigd bij de technische opleidingen en ondervertegenwoordigd bij de zorgopleidingen. Alleen bij de economische opleidingen ontloopt het aandeel mannen en vrouwen elkaar relatief weinig. Verder zijn de leerlingen bij economie iets ouder, en bij zorg iets jonger dan gemiddeld. Voor alle drie de richtingen geldt echter dat $50 \%$ van de leerlingen 18 jaar of jonger is. Wat betreft de herkomst blijkt dat autochtonen beduidend vaker voor een technische of een zorgopleiding kiezen. $60 \%$ van de allochtonen kiest voor een economische opleiding, terwijl de resterende $40 \%$ gelijk verdeeld is tussen de technische en de zorgopleidingen.

Voorts blijkt dat ruim $40 \%$ van de leerlingen op niveau 1 en 2 een technische opleiding volgt, terwijl leerlingen op niveau 3 of 4 juist eerder een zorgopleiding volgen. 
Verder blijkt dat er een oververtegenwoordiging van leerlingen is op niveau 1 in de economische opleidingen. Wat betreft de leerweg zien we dat bijna de helft van de $\mathrm{BBL}$-leerlingen van de nieuwe instroom een technische opleiding kiest, terwijl slechts $19 \%$ van de BOL'ers voor techniek kiest. Aansluitend op het relatief grote aandeel leerlingen van niveau 1 in de economische richting, laat tabel 6.2 zien dat de leerlingen van de economische opleidingen ook oververtegenwoordigd zijn onder degenen met een onderwijsachterstand. Deze oververtegenwoordiging van economie geldt niet voor leerlingen die geen diploma voor hun vooropleiding hebben behaald. Leerlingen die geen diploma behaald hebben voor hun vooropleiding kiezen iets vaker voor techniek en iets minder vaak voor de zorg in vergelijking met leerlingen die wel een diploma behaald hebben.

Tabel 6.2

Verdeling van eerstejaars leerlingen naar kenmerk over de drie sectoren techniek, economie en zorg, voorjaar 2005

\begin{tabular}{|c|c|c|c|c|c|c|}
\hline \multirow{2}{*}{\multicolumn{2}{|c|}{ Kenmerk }} & \multirow{2}{*}{$\begin{array}{r}\text { Techniek } \\
\%\end{array}$} & \multirow{2}{*}{$\begin{array}{r}\text { Economie } \\
\%\end{array}$} & \multirow{2}{*}{$\begin{array}{r}\text { Zorg } \\
\%\end{array}$} & \multicolumn{2}{|c|}{ Totaal } \\
\hline & & & & & $\mathrm{km}$. of jr & $(=100 \%)$ \\
\hline \multirow[t]{2}{*}{ Afstand (km.) } & Gemiddelde & 17,1 & 17,1 & 14,3 & 16,2 & \\
\hline & Mediaan & 13,0 & 11,1 & 11,3 & 11,7 & \\
\hline \multirow[t]{2}{*}{ Geslacht } & Man & 48 & 44 & 8 & & 8.443 \\
\hline & Vrouw & 4 & 38 & 59 & & 7.318 \\
\hline \multirow[t]{2}{*}{ Leeftijd (jr.) } & Gemiddelde & 20,5 & 20,0 & 21,1 & 20,5 & \\
\hline & Mediaan & 18 & 18 & 18 & 18 & \\
\hline \multirow[t]{2}{*}{ Herkomst } & Autochtoon & 28 & 39 & 33 & & 14.200 \\
\hline & Allochtoon & 20 & 60 & 20 & & 1.561 \\
\hline \multirow[t]{4}{*}{ Niveau } & 1 & 41 & 52 & 7 & & 825 \\
\hline & 2 & 41 & 40 & 19 & & 4.639 \\
\hline & 3 & 16 & 39 & 45 & & 3.710 \\
\hline & 4 & 22 & 42 & 36 & & 6.549 \\
\hline \multirow[t]{2}{*}{ Leerweg } & BOL & 19 & 46 & 35 & & 4.439 \\
\hline & BBL & 49 & 28 & 22 & & 11.322 \\
\hline \multirow[t]{2}{*}{ Leerachterstand } & Nee & 26 & 42 & 32 & & 11.603 \\
\hline & $\mathrm{Ja}^{*}$ & 27 & 46 & 27 & & 1.723 \\
\hline \multirow[t]{2}{*}{ Diploma vooropleiding } & $\mathrm{Ja}$ & 26 & 41 & 33 & & 12.054 \\
\hline & $\mathrm{Nee}^{\star \star}$ & 31 & 41 & 30 & & 3.503 \\
\hline \multicolumn{2}{|c|}{ Totale leerlingenpopulatie } & 27 & 41 & 32 & & 15.761 \\
\hline \multicolumn{7}{|c|}{$\begin{array}{ll}\text { * } & \text { Op basis van VOA-registratie, exclusief Koning Willem I College } \\
\text { ** Van ongeveer een kwart van de leerlingen is onbekend of zij een diploma van de } \\
\text { vooropleiding hebben behaald. Ook voor andere variabelen kan er informatie over } \\
\text { leerlingen ontbreken. }\end{array}$} \\
\hline
\end{tabular}


In tabel 6.3 gaan we verder in op de kenmerken van de leerlingen van elk van de vijf ROC's. In totaal gaat het om 15.761 eerstejaars leerlingen die studeren aan één van de vijf ROC's. Uit de tabel blijkt dat de eerstejaars leerlingen op gemiddeld iets meer dan 16 kilometer afstand van hun ROC wonen. De leerlingen van ROC ter AA zijn gemiddeld de kleinste afstand af. Zij wonen op ruim $12 \mathrm{~km}$ van hun school. De afstand van thuis naar school is voor leerlingen van Gilde opleidingen en ROC de Leijgraaf iets groter maar nog steeds minder dan het gemiddelde. De afstand van thuis naar school is voor leerlingen van het Koning Willem 1 College gemiddeld ruim $18 \mathrm{~km}$, en is voor leerlingen van ROC Eindhoven gemiddeld het hoogst, namelijk 22 $\mathrm{km}$.

\section{Tabel 6.3}

Karakteristieken van de eerstejaars leerlingen bij vijf ROC's in het Technogebied, nieuwe instroom, voorjaar 2005

\begin{tabular}{|c|c|c|c|c|c|c|}
\hline & $\begin{array}{l}\text { Totaal } \\
\text { ROC's }\end{array}$ & $\begin{array}{r}\text { ROC ter } \\
\text { AA }\end{array}$ & $\begin{array}{r}\text { Gilde } \\
\text { opleidingen }\end{array}$ & $\begin{array}{r}\mathrm{ROC} \\
\text { Eindhoven }\end{array}$ & $\begin{array}{c}\text { Koning } \\
\text { Willem I } \\
\text { College }\end{array}$ & $\begin{array}{r}\mathrm{ROC} \\
\mathrm{De} \\
\text { Leijgraaf }\end{array}$ \\
\hline $\begin{array}{l}\text { Aantal }(=100 \%) \\
\text { Afstand (km.) }\end{array}$ & 15.761 & 998 & 4.669 & 3.438 & 2.435 & 4.221 \\
\hline Gemiddelde & 16,2 & 12,4 & 13,3 & 22,0 & 18,3 & 14,5 \\
\hline Mediaan & 11,7 & 8,9 & 10,7 & 15,2 & 15,3 & 10,3 \\
\hline $\begin{array}{l}\text { Vrouw (\%) } \\
\text { Leeftijd (jr.) }\end{array}$ & 46 & 47 & 50 & 47 & 45 & 43 \\
\hline Gemiddelde & 20,5 & 19,4 & 20,0 & 21,4 & 17,8 & 22,2 \\
\hline Mediaan & 18 & 18 & 19 & 18 & 18 & 19 \\
\hline $\begin{array}{l}\text { Allochtoon }(\%) \\
\text { Leerachterstand }\end{array}$ & 10 & 14 & 11 & 12 & 9 & 6 \\
\hline $\begin{array}{l}\text { (\%) } \\
\text { Geen diploma }\end{array}$ & 13 & 1 & 21 & 8 & - & 11 \\
\hline $\begin{array}{l}\text { vooropl. (\%) } \\
\text { Niveau (\%) }\end{array}$ & 23 & 26 & 23 & 21 & 10 & 30 \\
\hline mong (t) & 5 & 2 & 3 & 7 & 4 & 8 \\
\hline $\begin{array}{l}2 \\
3\end{array}$ & 30 & 32 & 30 & 32 & 31 & 25 \\
\hline $\begin{array}{l}3 \\
4\end{array}$ & $\begin{array}{l}24 \\
42\end{array}$ & $\begin{array}{l}29 \\
36\end{array}$ & $\begin{array}{l}33 \\
34\end{array}$ & $\begin{array}{l}20 \\
41\end{array}$ & 11 & $\begin{array}{l}22 \\
45\end{array}$ \\
\hline Leerweg (\%) & & & & & & \\
\hline BBL & 28 & 22 & 27 & 31 & 24 & 31 \\
\hline Sector (\%) & & & & & & \\
\hline Techniek & 27,3 & 26,3 & 23,5 & 27,9 & 32,4 & 28,2 \\
\hline Economie & 41,1 & 38,0 & 41,5 & 43,7 & 34,8 & 42,9 \\
\hline Zorg & 31,6 & 35,8 & 35,0 & 28,4 & 32,8 & 28,9 \\
\hline
\end{tabular}

Bron: ROA / ROC Ter AA / Gilde Opleidingen / ROC Eindhoven / Koning Willem I College / ROC De Leijgraaf

Wat betreft de afstand tussen thuis en school is in tabel 6.3 ook de mediaan weergegeven. De mediaan van de afstand is minder gevoelig voor uitschieters naar boven dan de gemiddelde afstand. De mediaan van de afstand is $11,7 \mathrm{~km}$. voor alle ROC's. Dit betekent dat 50\% van de leerlingen op minder dan $11,7 \mathrm{~km}$. van de school woont. Voor ROC ter AA is de mediaan beduidend kleiner, voor ROC Eindhoven en Koning Willem I College beduidend groter. 
De percentages in tabel 6.3 geven het aandeel weer van leerlingen met een bepaald kenmerk in het totale aantal leerlingen van het betreffende ROC (of van het totaal aantal leerlingen over de vijf ROC's). Uit de tabel blijkt bijvoorbeeld dat Gilde opleidingen het grootste percentage vrouwen heeft (50\%) en ROC de Leijgraaf het kleinste (43\%). Voor de vijf ROC's gezamenlijk is $46 \%$ van de leerlingen van het vrouwelijke geslacht.

De gemiddelde leeftijd van 20,5 jaar van de eerstejaars leerlingen is vrij hoog te noemen $^{37}$ als men bedenkt dat leerlingen ongeveer 16 jaar oud zijn als ze de basisschool en het VMBO zonder vertraging doorlopen en aansluitend in het eerste jaar van het MBO instromen. Maar liefst $50 \%$ is ouder dan 18 jaar. De hogere leeftijd betekent dat er veel leerlingen zijn die van opleiding veranderen op het MBO. Verder is van belang dat de nieuwe instroom van BBL-leerlingen, die vaak al gewerkt hebben voordat ze een BBL-opleiding gaan volgen, gemiddeld ongeveer zes jaar ouder zijn dan de BOL-leerlingen.

In het Technogebied bestaat de nieuwe instroom voor ongeveer 10\% uit allochtone leerlingen. ROC ter AA heeft met bijna $14 \%$ het hoogste aandeel allochtonen in de nieuwe instroom, terwijl ROC de Leijgraaf het laagste aandeel allochtonen heeft. Gemiddeld heeft $13 \%$ van de eerstejaars leerlingen in het Technogebied een onderwijsachterstand. Bij Gilde Opleidingen is dit percentage $21 \%$, terwijl het voor de andere ROC's (in het bijzonder ROC Ter AA) aanzienlijk lager ligt. ${ }^{38}$ Van de nieuwe instroom leerlingen in het Technogebied heeft $22,5 \%$ geen diploma uit een vooropleiding behaald. Met ongeveer $30 \%$ is dit percentage bij ROC de Leijgraaf het hoogst. Bij het Koning Willem 1 College daarentegen heeft slechts $10 \%$ geen diploma van een vooropleiding.

In het Technogebied is volgt slechts $5 \%$ van de leerlingen een opleiding op niveau 1 , $30 \%$ op niveau 2, $24 \%$ op niveau 3 en $42 \%$ op niveau 4 . De nieuwe instroom van leerlingen bij de vijf ROC's in het Technogebied bestaat gemiddeld uit $72 \%$ BOL'ers en $28 \%$ BBL'ers. Het verschil tussen het ROC's met het hoogste en laagste aandeel BBL bedraagt bijna 10\%-punt. Op ROC ter AA kiest 22\% van de nieuwe leerlingen voor een BBL-opleiding, terwijl dit bij de ROC's Eindhoven en de Leijgraaf $31 \%$ is.

Uit tabel 6.3 blijkt dat het aandeel leerlingen dat voor een technische opleiding gekozen heeft bij Gilde Opleidingen het laagst is, namelijk 23,5\%. Bij ROC ter AA koos $26,3 \%$ van de nieuwe instroom voor een technische opleiding, terwijl ROC Eindhoven en ROC de Leijgraaf beide $28 \%$ van de nieuwe instroom voor techniek zagen kiezen. Koning Willem 1 college kent met $32 \%$ duidelijk het hoogste percentage nieuwe instroom van leerlingen in een technische opleiding.

37. Het gaat om de leeftijd van de leerlingen op 1 januari 2005.

38. Bij Koning Willem 1 College wordt de onderwijsachterstand niet geregistreerd. Bij de overige ROC's zijn de verschillen in het aandeel leerlingen met een onderwijsachterstand erg groot. Deze verschillen lijken eerder te wijten aan andere manier van registreren door elk ROC dan aan grote verschillen tussen de eerstejaarsleerlingen van de vier overige ROC's. 
Verder blijkt uit tabel 6.3 dat economische opleidingen het meest worden gekozen door de eerstejaars leerlingen die naar ROC Eindhoven gaan, en het minst door de eerstejaars leerlingen van Koning Willem I College. Voor de zorgopleidingen wordt bij ROC Eindhoven het minst gekozen. Bij ROC Ter AA in Helmond kiest men juist het meest voor een zorgopleiding.

\subsection{Motieven en achtergronden bij de keuze voor techniek}

Aan de hand van een steekproef onder eerstejaars leerlingen van vier ROC's in Zuidoost Nederland is getracht te achterhalen wat de motieven en achtergronden zijn van leerlingen bij de keuze voor techniek. Er is een beperkt aantal eerstejaars techniek- en economieleerlingen van Gilde Opleidingen, ROC Eindhoven, ROC De Leijgraaf en Koning Willem I College geënquêteerd. Het bestand dat is samengesteld op basis van de leerlingenenquête kan na diverse selecties en na weging ${ }^{39}$ als representatief worden beschouwd voor de mannelijke leerlingen die de beroepsopleidende leerweg (BOL) volgen op niveau 2 of 4 aan één van de vier bovengenoemde ROC's (niet ROC Ter Aa) in de richting techniek of economie. Door de weging naar ROC wordt ook de verdeling van niveau 2 of 4 binnen de richting techniek in de goede richting bijgesteld. De aanvankelijke sterke oververtegenwoordiging van niveau 4 in de steekproef wordt sterk gereduceerd. Er is echter nog steeds sprake van een lichte oververtegenwoordiging van niveau 4 bij techniek. Hieraan zal waar nodig in de volgende paragrafen worden gerefereerd.

In het navolgende worden de resultaten van de gewogen steekproef van leerlingen gepresenteerd. Allereerst zal aandacht worden besteed aan persoonlijke achtergrond van de leerlingen. Vervolgens wordt gekeken naar de determinanten bij de opleidingskeuze en de keuze voor de school. Als laatste zal de invloed van de reistijd op de studiekeuze nader worden onderzocht.

\section{Achtergrondkenmerken van leerlingen en ouders}

De studiekeuze van leerlingen is voor een groot deel afhankelijk van de persoonlijke achtergrond. De achtergrond van leerlingen wordt gevormd door de persoonlijke kenmerken van het individu en de kenmerken van de leefomgeving van de leerling. In tabel 6.4 worden enkele kenmerken van de leerlingen uit de steekproef getoond.

Uit tabel 6.4 blijkt dat het merendeel van de MBO-leerlingen het VMBO als vooropleiding had (94\% voor economieleerlingen en $96 \%$ voor techniekleerlingen). De overige leerlingen hadden een hogere opleiding (HAVO). Daarbij valt op dat in de

39. Voor de weging is een selectie van de populatie van eerstejaarsleerlingen uit de leerlingenadministratie gebruikt. Het betreft een selectie van 3.886 leerlingen uit het totaal van 15.761 eerstejaars leerlingen. Zie voor nadere toelichting Bijlage 7. 
economie iets meer leerlingen een HAVO-achtergrond hebben dan het geval is bij techniek (verschil is $2 \%$-punt).

Tabel 6.4

Gegevens over vooropleiding van leerlingen naar opleidingsrichting

\begin{tabular}{|c|c|c|}
\hline & $\begin{array}{r}\text { Economie } \\
\%\end{array}$ & $\begin{array}{r}\text { Techniek } \\
\%\end{array}$ \\
\hline \multicolumn{3}{|l|}{ Vooropleiding } \\
\hline VMBO & 94 & 96 \\
\hline HAVO & 6 & 4 \\
\hline MBO & 0 & 0 \\
\hline Totaal & 100 & 100 \\
\hline \multicolumn{3}{|l|}{ Leerweg VMBO (vooropleiding) } \\
\hline Theoretische of Gemengde leerweg & 47 & 59 \\
\hline Kaderberoepsgericht & 22 & 23 \\
\hline Basisberoepsgericht & 31 & 18 \\
\hline Totaal & 100 & 100 \\
\hline \multicolumn{3}{|l|}{ Diploma vooropleiding behaald } \\
\hline Behaald & 94 & 94 \\
\hline Niet behaald & 6 & 6 \\
\hline Totaal & 100 & 100 \\
\hline \multicolumn{3}{|l|}{ Duur vooropleiding } \\
\hline 1 jaar & 2 & 0 \\
\hline 2 jaar & 8 & 4 \\
\hline 3 jaar & 2 & 0 \\
\hline 4 jaar & $7 \overline{7}$ & 85 \\
\hline 5 jaar & 8 & 8 \\
\hline 6 jaar & 2 & 2 \\
\hline Meer dan 6 jaar & 0 & 0 \\
\hline Totaal & 100 & 100 \\
\hline
\end{tabular}

Van de leerlingen met een VMBO techniek achtergrond in de steekproef heeft $59 \%$ de Theoretische of Gemengde leerweg gevolgd. Voor economieleerlingen is dit $47 \%$. Het blijkt dat techniekleerlingen vaker de leerwegen met de hoogste moeilijkheidsgraad hebben gevolgd op het VMBO. Hierbij speelt waarschijnlijk de oververtegenwoordiging van kwalificatieniveau 4 onder techniekleerlingen een rol. Dit kan ook verklaren dat economieleerlingen vaker kiezen voor de Basisberoepsgerichte leerweg (de leerweg met de laagste moeilijksheidsgraad). Voor zowel techniek- als economieleerlingen geldt dat $94 \%$ het diploma van de voorafgaande opleiding heeft behaald. Het merendeel van de leerlingen heeft het diploma van de voorafgaande opleiding behaald in 4 jaar.

Een belangrijke factor in de leefomgeving is de achtergrond van de ouders van de leerling. In tabel 6.5 wordt de opleidingsachtergrond weergegeven van zowel de vader als moeder. Er zijn vragen gesteld over de hoogst behaalde opleiding, de richting waarin de ouders werkzaam zijn en of de leerling ook werkzaam wil zijn in dezelfde richting als zijn / haar ouders. 
Tabel 6.5

Opleidingsachtergrond van ouders en voorkeur van leerlingen voor beroep van ouders naar opleidingsrichting

$\begin{array}{lrr} & \text { Economie } & \text { Techniek } \\ & \%\end{array}$

Moeder

Hoogst behaalde opleiding

Laagopgeleid

Middelbaar opgeleid

Hoog opgeleid

Totaal

$48 \quad 42$

Niet Technisch

$100 \quad 100$

Technisch

Totaal

$100 \quad 100$

$100 \quad 100$

Voorkeur van leerling voor hetzelfde

beroep als ouders

Zelfde als vader

Zelfde als moeder

Ander beroep dan ouders

Totaal

$\begin{array}{rr}16 & 48 \\ 8 & 4 \\ 76 & 48 \\ 100 & 100\end{array}$

De opleidingsachtergrond van de vaders van MBO leerlingen is veelal laag. ${ }^{40}$ Voor zowel techniek- als economieleerlingen geldt dat ongeveer $40 \%$ van de vaders laaggeschoold is. Tevens bestaat er weinig verschil tussen het opleidingsniveau van de vaders van economie- en techniekleerlingen Als tweede valt op dat vaders van techniekleerlingen vaker werkzaam zijn in de techniek en bouw. Ruim twee derde is werkzaam in deze sectoren), terwijl vaders van de economieleerlingen vooral werkzaam zijn buiten de techniek. ${ }^{41}$

40. Onder laagopgeleid wordt volstaan: Lagere school, Lagere beroepsopleiding (bijvoorbeeld LTS, Huishoudschool etc) en MAVO of MULO. Onder middelbaar opgeleid wordt verstaan: HAVO, MMS, VWO, HBS of Gymnasium en MBO of Leerlingwezen. Onder hoogopgeleid wordt HBO en Universiteit verstaan.

41. Het merendeel van de vaders van de economieleerlingen is werkzaam in de ICT, Economie en Administratie en de Handel, Transport en Logistiek. 
De opleidingsachtergrond van de moeders van $\mathrm{MBO}$ leerlingen verschilt van die van de vaders. Er zijn relatief meer moeders van MBO leerlingen laag of middelbaar opgeleid (87\% voor economie en $92 \%$ voor techniek) dan het geval is voor de vaders. Daarnaast zijn relatief veel moeders van techniekleerlingen laagopgeleid (verschil met moeders van economie leerlingen is $11 \%$-punt). De moeders die betaald werk verrichten (ruim de helft), zijn bijna allemaal werkzaam buiten de techniek. $^{42}$

Voorts is aan de leerlingen de vraag gesteld of zij later werkzaam willen zijn in hetzelfde beroep als de vader of moeder, of dat zij een volledig ander beroep willen uitoefenen. Uit de tabel blijkt dat techniekleerlingen vaak in hetzelfde beroep werkzaam willen zijn als dat van hun vader. Economieleerlingen geven vaker dan techniekleerlingen aan werkzaam te willen zijn in het beroep van hun moeder. Per saldo kiest echter een relatief groot deel van de (mannelijke) techniekleerlingen hetzelfde beroep als één van hun ouders, in het bijzonder dat van hun vader. Dat is vooral van belang omdat de vaders van techniekleerlingen relatief vaak in een technisch beroep werkzaam zijn.

\section{Determinanten bij de studiekeuze}

In de leerlingenenquête zijn vragen gesteld over welke factoren een rol gespeeld hebben bij de keuze voor de huidige $M B O$ opleiding. In tabel 6.6 worden de belangrijkste resultaten gepresenteerd naar opleidingsrichting. De vragen zijn in drie rubrieken ondergebracht:

- Interesse in vakgebied

- Carrièrefactoren

- Invloed door omgeving

De tabel toont dat de interesse in het vakgebied voor zowel economie- als techniekleerlingen een doorslaggevende rol speelt. Zowel bij de vraag of de opleiding aansluit bij de eigen interesse en of de opleiding leuk lijkt geeft een grote groep leerlingen aan dat dit relevant is geweest bij de opleidingskeuze. Echter voor techniekleerlingen lijkt de interesse in het vakgebied een iets belangrijkere factor te zijn dan voor economieleerlingen het geval is, aangezien de score op beide vragen 9 en $4 \%$-punten hoger ligt. Hierbij kan echter de oververtegenwoordiging van niveau 4 leerlingen bij techniek een rol spelen. Techniekleerlingen geven eveneens meer dan economieleerlingen aan dat zij de studiekeuze hebben laten beïnvloeden door het aantal praktijklessen (verschil bedraagt $26 \%$-punten). Dit is vooral opmerkelijk omdat het hier uitsluitend gaat om BOL-leerlingen.

Ook carrièrefactoren spelen een belangrijke rol, hoewel de scores hierop beduidend lager zijn dan bij de interesse in het vakgebied. Ongeveer $40 \%$ van de ondervraagden geeft aan dat zij zich bij hun studiekeuze hebben laten leiden door de kans op werk of het krijgen van een leuke baan. Er zijn geen duidelijk verschillen zichtbaar

42. De meeste werkzame moeders hebben een baan in de richtingen Economie en Administratie en de Gezondheidszorg. 
tussen economie- en techniekleerlingen. Wel is er verschil in het belang dat gehecht wordt aan de mogelijkheid om door te stromen naar een opleiding op HBO-niveau. Interessant is dat ruim $38 \%$ van de economieleerlingen aangeeft dat zij hiermee rekening heeft gehouden, terwijl dit slechts $26 \%$ is voor techniekleerlingen.

Tabel 6.6

Determinanten bij de studiekeuze naar opleidingsrichting, percentage van de leerlingen dat aangeeft de betreffende determinant belangrijk te vinden (meer antwoorden mogelijk)

\begin{tabular}{rr}
\hline & Economie \\
$\%$ & Techniek \\
& $\%$
\end{tabular}

\section{Interesse in vakgebied}

$\begin{array}{lll}\text { Opleiding sluit aan bij interesse } & 70 & 79\end{array}$

Het lijkt me een leuke opleiding

$\begin{array}{lrr}\text { Er zijn veel praktijklessen } & 6 & 32\end{array}$

\section{Carrièrefactoren}

Er volgen maar weinig leerlingen deze opleiding $\quad 14 \quad 4$

$\begin{array}{lll}\text { De opleiding biedt goede kansen op werk } & 38 & 40\end{array}$

$\begin{array}{lll}\text { Met deze opleiding kun je een leuke baan krijgen } & 36 & 38\end{array}$

Met deze opleiding kan ik doorstromen 38

naar de HBO opleiding die ik wil gaan doen $\quad 38 \quad 26$

\section{Invloed door omgeving}

De opleiding is aanbevolen door anderen $\quad 22 \quad 9$

Mijn beste vriend(in) volgt deze opleiding ook $\quad 6 \quad 11$

Een laatste bepalende factor bij de studiekeuze is de invloed van de omgeving van de leerling. In verhouding tot de interesse in het vakgebied en de carrièrefactoren speelt de invloed van de omgeving een ondergeschikte rol. Desondanks geeft nog $22 \%$ van de economieleerlingen aan dat de aanbeveling van anderen een rol speelt bij de keuze van de huidige opleiding. Bij techniekleerlingen is dit significant minder vaak het geval.

In de leerlingenenquête is tevens gevraagd om een score te geven aan het belang van vier verschillende factoren bij de studiekeuze, namelijk:

- Interesse in vakgebied

- Aantrekkelijkheid van de school

- Aantrekkelijkheid van de schoolomgeving

- Reistijd naar de school

In tabel 6.7 is aangeven wat de relevantie is van een aantal factoren bij de opleidingskeuze. Een ruime meerderheid van de leerlingen geeft aan dat de interesse voor het vak / beroep belangrijk tot zeer belangrijk is bij de keuze van hun opleiding, te weten $84 \%$ voor techniekleerlingen en $76 \%$ voor economieleerlingen. Aan dit verschil moet niet meteen teveel waarde worden gehecht, omdat leerlingen van niveau 4 iets oververtegenwoordigd zijn onder de techniekleerlingen. 
Tabel 6.7

Factoren die een rol speelden bij de studiekeuze naar opleidingsrichting

Economie Techniek

Hoe belangrijk is jouw interesse voor

het vak/beroep bij de keuze van je opleiding?

Zeer onbelangrijk

Onbelangrijk

Neutraal

Belangrijk

Zeer belangrijk

Totaal

$\begin{array}{rr}2 & 15 \\ 0 & 0 \\ 14 & 9 \\ 43 & 57 \\ 41 & 19 \\ 100 & 100\end{array}$

Hoe belangrijk is de school

zelf bij de keuze van je opleiding?

Zeer onbelangrijk

Onbelangrijk

Neutraal

Belangrijk

Zeer belangrijk

Totaal

$\begin{array}{rr}2 & 0 \\ 2 & 4 \\ 35 & 38 \\ 53 & 45 \\ 8 & 13 \\ 100 & 100\end{array}$

Hoe belangrijk is de stad of de plaats

van de school bij de keuze van je opleiding?

Zeer onbelangrijk

Onbelangrijk

Neutraal

Belangrijk

Zeer belangrijk

Totaal

$\begin{array}{rr}6 & 7 \\ 8 & 20 \\ 33 & 33 \\ 51 & 33 \\ 2 & 9 \\ 100 & 100\end{array}$

Hoe belangrijk is de reistijd naar

school bij de keuze van je opleiding?

Zeer onbelangrijk

Onbelangrijk

Neutraal

Belangrijk

Zeer belangrijk

Totaal

$\begin{array}{rr}8 & 0 \\ 8 & 8 \\ 33 & 52 \\ 40 & 27 \\ 10 & 13 \\ 100 & 100\end{array}$

Ongeveer $60 \%$ van de techniek- en economieleerlingen vindt de school belangrijk of zeer belangrijk bij de keuze van de opleiding. Voor leerlingen van beide richtingen geldt dat de school over het algemeen minder belangrijk is dan de interesse voor het vakgebied. Ruim 53\% van de economie- en $41 \%$ van de techniekleerlingen geeft aan dat de stad of plaats bij de keuze van de opleiding een (zeer) belangrijke rol heeft gespeeld. Techniekleerlingen vinden de omgeving van de school dus beduidend minder belangrijk dan techniekleerlingen. Tevens geeft ongeveer de helft van de economieleerlingen aan dat de reistijd een (zeer) belangrijke factor was bij de studiekeuze. Techniekleerlingen vinden de reistijd veel minder belangrijk bij hun studiekeuze. Toch vindt nog $40 \%$ van de techniekleerlingen de reistijd belangrijk of zeer belangrijk. Hoewel het hier om een relatief grote groep leerlingen gaat, is het belang van de reistijd kleiner dan de interesse voor het vak en de aantrekkelijkheid van de school. 
Tabel 6.8 geeft weer in hoeverre leerlingen gedacht hebben aan het volgen van een andere opleiding dan die zij gekozen hebben en in welke richting de alternatieve opleiding valt. De tabel geeft een indicatie over het enthousiasme en de twijfel over de gekozen opleiding, en de spijt achteraf van de opleidings- en schoolkeuze.

Tabel 6.8

Twijfel en tevredenheid bij studiekeuze naar opleidingsrichting

\begin{tabular}{|c|c|c|}
\hline & $\begin{array}{r}\text { Economie } \\
\%\end{array}$ & $\begin{array}{r}\text { Techniek } \\
\%\end{array}$ \\
\hline \multicolumn{3}{|l|}{ Naast huidige opleiding ook aan andere opleiding gedacht } \\
\hline $\mathrm{Ja}$ & 47 & 62 \\
\hline Nee & 53 & 38 \\
\hline Totaal & 100 & 100 \\
\hline \multicolumn{3}{|l|}{ Richting alternatieve opleiding } \\
\hline Niet technisch & 88 & 35 \\
\hline Technisch & 13 & 65 \\
\hline Totaal & 100 & 100 \\
\hline \multicolumn{3}{|l|}{$\begin{array}{l}\text { Opleidingenaanbod op leslocatie beïnvloedt opleidingskeuze } \\
\text { (zou men van opleiding veranderen als men } \\
\text { alle opleidingen kan volgen op dezelfde locatie) }\end{array}$} \\
\hline $\mathrm{Ja}$ & 26 & 28 \\
\hline Nee & 74 & 72 \\
\hline Totaal & 100 & 100 \\
\hline \multicolumn{3}{|l|}{$\begin{array}{l}\text { Richting opleiding als alle opleidingen } \\
\text { worden aangeboden op dezelfde locatie }\end{array}$} \\
\hline Niet technisch & 67 & 43 \\
\hline Technisch & 33 & 57 \\
\hline Totaal & 100 & 100 \\
\hline \multicolumn{3}{|l|}{ Tevreden met keuze huidige opleiding } \\
\hline Ja, ik zou opnieuw kiezen voor deze opleiding, aan dezelfde & 65 & 69 \\
\hline Ja, ik zou opnieuw kiezen voor dezelfde opleiding, maar aan andere school & 18 & 15 \\
\hline Nee, ik zou een andere opleiding kiezen, aan dezelfde school & 2 & 6 \\
\hline Nee, ik zou een andere opleiding kiezen en aan een andere school & 14 & 10 \\
\hline Nee, ik zou liever geen opleiding hebben gevolgd & 0 & 0 \\
\hline Totaal & 100 & 100 \\
\hline
\end{tabular}

Voor zowel techniek- als economieleerlingen blijkt dat het merendeel serieus heeft nagedacht over het volgen van een andere opleiding. Vooral techniekleerlingen hebben relatief vaak een andere opleiding overwogen, namelijk $62 \%$ van alle leerlingen die nu een technische opleiding volgen. Wat opvalt is dat $35 \%$ van de techniekleerlingen die serieus nadachten over een andere opleiding, een niettechnische opleiding hebben overwogen. Voor de economieleerlingen die nadachten over een andere opleiding geldt dat $88 \%$ een alternatieve niet-technische opleiding heeft overwogen. Hieruit blijkt dat techniekleerlingen meer getwijfeld hebben bij hun opleidingskeuze dan economieleerlingen. Bovendien is hun alternatief relatief vaak een niet-technische opleiding.

Vervolgens is nagegaan of leerlingen voor een andere opleiding zouden hebben gekozen als alle bestaande opleidingen op hun huidige leslocatie worden aange- 
boden. Uit de respons blijkt dat ruim $70 \%$ van de leerlingen weer zou kiezen voor dezelfde opleiding, terwijl ongeveer $30 \%$ zou kiezen voor een andere opleiding. Het grootste gedeelte van de leerlingen lijkt dus door het bestaande opleidingenaanbod niet te worden gelimiteerd bij hun studiekeuze. Van de economieleerlingen die een andere opleiding zouden willen volgen op dezelfde leslocatie zou $67 \%$ weer kiezen voor een niet-technische opleiding. Van de techniekleerlingen zou daarentegen $43 \%$ een niet-technische opleiding kiezen. Ofwel veel van de techniekleerlingen die aangeven van opleiding te veranderen bij een breed opleidingenaanbod, zou kiezen voor een niet-technische opleiding.

Tot slot valt geen groot onderscheid te ontdekken tussen de tevredenheid over de huidige opleiding van techniek- en economieleerlingen. Ondanks de grotere twijfel bij de studiekeuze van techniekleerlingen en de grote groep techniekleerlingen die zou kiezen voor een niet-technische opleiding bij een breed opleidingenaanbod, zijn techniekleerlingen ongeveer even tevreden over hun studie- en schoolkeuze als economieleerlingen. Toch kan uit tabel 6.8 (richting alternatieve opleiding en opleidingskeuze als opleidingenaanbod maximaal is) geconcludeerd worden dat de techniekleerlingen die twijfelen de overstap naar een niet-technische opleiding gemakkelijker maken dan dat twijfelende economieleerlingen zouden kiezen voor een technische opleiding.

\section{Determinanten bij de schoolkeuze}

Uit tabel 6.9 blijkt dat de aantrekkingskracht van een school vooral bepaald wordt door hoe leuk leerlingen een school vinden. Dit geldt voor techniekleerlingen in sterkere mate dan voor economieleerlingen. Daarnaast blijkt dat vooral de praktijklessen door techniekleerlingen van relatief groot belang gevonden bij de schoolkeuze. Techniekleerlingen laten zich iets minder leiden door de computervoorzieningen en de discipline op de school, terwijl de computervoorzieningen voor economieleerlingen relatief belangrijk zijn. Deze grotere interesse in de computervoorzieningen kan verklaard worden doordat er relatief veel economieleerlingen een (niet-technische) ICT-opleiding volgen.

Met betrekking tot de locatie van de school blijken er belangrijke verschillen tussen techniek- en economieleerlingen te zijn. Economieleerlingen vinden het belangrijker dat hun school in een leuke stad en dichtbij huis ligt. Het verschil met techniekleerlingen bedraagt respectievelijk 7 en $21 \%$-punt. Techniekleerlingen vinden het vooral belangrijk dat de school goed te bereiken is met het openbaar vervoer. Het verschil met economieleerlingen bedraagt $10 \%$-punt. Dit laatste wordt veroorzaakt, zoals nog zal blijken, doordat techniekleerlingen vaker met het openbaar vervoer reizen.

Bij de invloed van de omgeving op de schoolkeuze valt waar te nemen dat techniekleerlingen zich iets vaker laten leiden door aanbevelingen van anderen, terwijl economieleerlingen vaker een school kiezen omdat een vriend(in) op die school zit. Deze resultaten zijn in combinatie met de resultaten over de invloed van de omgeving op de opleidingskeuze (tabel 6.6) moeilijk te interpreteren. Er kunnen 
derhalve nauwelijks conclusies worden getrokken over de invloed van de omgeving met uitzondering van de invloed van de vader (tabel 6.5) - op de keuze die leerlingen maken voor een bepaalde opleiding en school.

Tabel 6.9

Factoren die een rol speelden bij de schoolkeuze naar opleidingsrichting

\begin{tabular}{lrr} 
& $\begin{array}{r}\text { Economie } \\
\%\end{array}$ & $\begin{array}{r}\text { Techniek } \\
\%\end{array}$ \\
\hline Kenmerken school & & \\
Het leek me een leuke school & 42 & 55 \\
Computervoorzieningen & 26 & 11 \\
Manier van lesgeven & 24 & 26 \\
Discipline op school & 6 & 0 \\
Praktijklessen & 2 & 34 \\
Locatie school & & \\
In de regio waar ik woon kun je & & 23 \\
mijn opleiding alleen op deze school volgen & 22 & 38 \\
De school ligt in een leuke stad & 18 & 21 \\
De school is goed te bereiken met het OV & 28 & \\
School ligt dicht bij mijn huis & 42 & 9 \\
Invloed door omgeving & & \\
De school is aanbevolen door anderen & 2 & \\
Mijn beste vriend(in) zit ook op deze school & 12 & \\
\hline
\end{tabular}

\section{Reistijd en vervoer}

Tabel 6.10 geeft de vervoermiddelen weer die de leerlingen gebruiken om naar school te gaan, de reistijd naar school, de afstand tussen school en thuis, de maximaal gewenste reistijd naar school, de reistijd naar de dichtstbijzijnde school met dezelfde opleiding en de reistijd naar een andere opleiding indien men bij de studiekeuze een andere opleiding heeft overwogen.

Leerlingen kunnen op verschillende wijzen reizen naar hun school. Hier worden drie categorieën onderscheiden:

- $\quad$ Ongemotoriseerd (fiets en te voet)

- $\quad$ Gemotoriseerd (snorfiets, bromfiets, scooter, motor en auto)

- Openbaar vervoer (bus en trein)

Van belang is dat uit de tabel blijkt dat techniekleerlingen meer gemotoriseerd of met het openbaar vervoer reizen. Ruim 85\% van de techniek leerlingen uit de steekproef van de enquête maken gebruik van een gemotoriseerd voertuig of het openbaar vervoer, tegen $62 \%$ van de economieleerlingen. Dit is in overeenstemming met de eerdere bevinding dat techniekleerlingen meer waarde hechten aan de bereikbaarheid van hun school met het openbaar vervoer. 
De verdeling van de reistijd naar de huidige school over techniekleerlingen lijkt te verschillen van die van niet-techniek leerlingen. De grootste groep techniekleerlingen heeft een reistijd tussen 16 en 30 minuten. Daarnaast zijn er, in verhouding met economieleerlingen, weinig techniekleerlingen die een zeer korte (korter dan 15 minuten) of zeer lange reistijd (langer dan 61 minuten) hebben. Bij economieleerlingen bestaat daarentegen meer heterogeniteit in de reistijd van de leerlingen. De groepen met een reistijd tussen 16 en 60 minuten zijn iets kleiner, terwijl de groepen met een zeer korte reistijd of een zeer lange reistijd beduidend groter zijn. Echter, de gemiddelde reistijd voor techniek- en economieleerlingen, ongeacht de afstand die men aflegt, is nagenoeg gelijk (33 minuten voor economie en 34 minuten voor techniek).

Tabel 6.10

Reistijd en vervoer naar opleidingsrichting

\begin{tabular}{|c|c|c|}
\hline & $\begin{array}{r}\text { Economie } \\
\%\end{array}$ & $\begin{array}{r}\text { Techniek } \\
\%\end{array}$ \\
\hline \multicolumn{3}{|l|}{ Vervoersmiddel } \\
\hline Ongemotoriseerd & 38 & 13 \\
\hline Gemotoriseerd & 20 & 34 \\
\hline Openbaar vervoer & 42 & 51 \\
\hline Totaal & 100 & 100 \\
\hline \multicolumn{3}{|c|}{ Reistijd naar huidige school in minuten } \\
\hline 1 tot 15 & 32 & \\
\hline 16 tot 30 & 28 & 49 \\
\hline 31 tot 60 & 28 & 38 \\
\hline 61 en langer & 12 & 4 \\
\hline Totaal & 100 & 100 \\
\hline \multicolumn{3}{|c|}{ Afstand naar huidige school in kilometers } \\
\hline 0 tot 5 & 41 & 13 \\
\hline 5 tot 15 & 37 & 56 \\
\hline 15 tot 30 & 10 & 30 \\
\hline 30 en verder & 12 & 0 \\
\hline Totaal & 100 & 100 \\
\hline \multicolumn{3}{|c|}{ Maximale gewenste reistijd naar huidige school in minuten } \\
\hline 1 tot 15 & 20 & 17 \\
\hline 16 tot 30 & 20 & 24 \\
\hline 31 tot 60 & 40 & 55 \\
\hline 61 en langer & 20 & 3 \\
\hline Totaal & 100 & 100 \\
\hline \multicolumn{3}{|c|}{ Reistijd naar dichtstbijzijnde school met dezelfde opleiding in minuten } \\
\hline 1 tot 15 & 13 & \\
\hline 16 tot 30 & 33 & 24 \\
\hline 31 tot 60 & 42 & 59 \\
\hline en langer & 13 & 18 \\
\hline Totaal & 100 & 100 \\
\hline \multicolumn{3}{|c|}{ Reistijd naar andere overwogen opleiding in minuten } \\
\hline ot 15 & 8 & 8 \\
\hline 16 tot 30 & 39 & 42 \\
\hline 31 tot 60 & 31 & 42 \\
\hline 61 en langer & 23 & \\
\hline taal & 100 & 100 \\
\hline
\end{tabular}

Uit tabel 6.10 blijkt verder dat relatief veel economieleerlingen (41\%) op minder dan 5 $\mathrm{km}$. van hun school wonen. Van de techniekleerlingen moet $30 \%$ een afstand overbruggen tussen 15 en 30 kilometer, tegenover slechts $10 \%$ van de economieleerlingen. Echter, bij de economieleerlingen geldt dat een kleine groep 
leerlingen een lange afstand moet afleggen vanuit hun woonadres naar school. Zij moeten verder reizen dan 30 kilometer. Als gevolg hiervan wijkt de gemiddelde afstand is nauwelijks verschillend tussen techniek- en economieleerlingen (13,2 en 13,0 km.), terwijl de mediaan bij techniekleerlingen beduidend hoger ligt dan bij techniekleerlingen, namelijk $13,6 \mathrm{~km}$. tegenover slechts $7,8 \mathrm{~km}$. voor economieleerlingen. ${ }^{43}$ Gelet op de geringe verschillen tussen de gemiddeldes van de reistijden van techniek- en economieleerlingen betekent dit dat veel techniekleerlingen een potentiële belemmering bij de studiekeuze, namelijk een grotere reisafstand, overwinnen door gebruik te maken van snellere transportmiddelen. ${ }^{44}$

Er is tevens aan de leerlingen gevraagd hoe ver men maximaal wil reizen naar de huidige school. Het blijkt dat leerlingen over het algemeen bereid zijn om een iets langere reistijd te willen accepteren dan dat ze op dit moment doen. Bij zowel economie als techniek is immers het aandeel leerlingen in de hoogste twee klassen van de maximaal gewenste reistijd iets groter dan het aandeel bij de huidige reistijd. De huidige reistijd verklaart derhalve voor een belangrijk deel de maximale reistijd die men zegt te willen besteden. Ook hier geldt dat de maximale gewenste reistijd naar de huidige school meer gespreid ligt voor de economieleerlingen.

Van belang is dat er nauwelijks techniekleerlingen zijn die meer dan een uur bereid zijn om te reizen naar hun school. De techniekleerlingen willen over het algemeen dus wel verder reizen dan ze nu doen, met de restrictie dat de reistijd niet meer dan uur mag zijn. De techniekleerlingen die de langste reistijd hebben - half uur tot een uur of meer - en de grootste reisafstand (van 15 tot $30 \mathrm{~km}$.) afleggen, zijn dus nauwelijks bereid om langer of verder te reizen. Grofweg kan gesteld worden dat er voor techniekleerlingen die maximaal $30 \mathrm{~km}$. of een uur reizen nog weinig 'rek' in de reistijd of reisafstand zit. Voor een klein deel van de economieleerlingen lijkt er daarentegen wat meer 'rek' te zitten als het gaat om relatief grote reisafstanden en lange reistijden.

Economieleerlingen wonen relatief vaak op korte afstand (tot 30 minuten) van een andere school in de regio die dezelfde opleiding aanbiedt. Techniekleerlingen zouden voor een alternatieve school met dezelfde opleiding als die ze nu volgen verder moeten reizen. Dit kan een indicatie zijn dat het opleidingenaanbod (het gaat hier ook om deelopleidingen binnen techniek of economie) in de technische richting

43. Het gemiddelde en de mediaan van de reisafstand zijn berekend op het gewogen steekproefbestand van geselecteerde leerlingen (zie Bijlage 7 ) in plaats van de totale populatie van eerstejaars leerlingen, en wijken dus af van de uitkomsten die in tabel 6.2 (en in Bijlage 9) zijn gepresenteerd. In beide gevallen geldt echter dat de spreiding qua reisafstand en reistijd groter is onder economieleerlingen dan onder techniekleerlingen.

44. De reistijd kan voor ruim twee derde worden verklaard uit de reisafstand volgens de regressievergelijking: tijd $=12,46+1,67^{*}$ afstand. De beide geschatte coëfficiënten zijn statistisch significant op 1\%-niveau. Dat betekent dat een afstand tot $30 \mathrm{~km}$. in ongeveer 1 uur kan worden overbrugd. 
meer geconcentreerd is dan in de economische richting. ${ }^{45}$

Als laatste is aan leerlingen die serieus hebben nagedacht over een andere opleiding de vraag gesteld hoe lang volgens hun inschatting de reistijd is naar die alternatieve opleiding. Zoals eerder is gebleken zijn de alternatieve opleidingen van economieleerlingen eveneens niet-technisch van aard. Vooral onder de economieleerlingen bestaat een grote groep waarvoor de reistijd naar de alternatieve opleiding betrekkelijk groot is. Economieleerlingen zouden voor het volgen van een alternatieve opleiding relatief vaak meer dan 60 minuten moeten reizen. De reistijd naar de school van de alternatieve opleiding kan worden afgezet tegen de maximaal gewenste reistijd. Er volgt dan dat voor de alternatieve opleidingen waarvoor meer dan 60 minuten gereisd moet worden, de reistijd voor een deel van de economie- en techniekleerlingen een belemmering kan zijn geweest. Deze leerlingen hebben dan mogelijk voor een opleiding gekozen op een kortere afstand van hun woonadres.

\subsection{Conclusies}

Spreiding van aanbod van technische opleidingen speelt nauwelijks een rol voor deelname aan techniek in Technogebied

Er lijkt geen sprake te zijn van een te beperkt aanbod van technische opleidingen in de verschillende regio's van het Technogebied Zuidoost-Nederland. De ruimtelijke spreiding van het aanbod van opleidingen in de technische richting is nauwelijks kleiner dan dat in andere richtingen. Een grotere spreiding van locaties waar technische opleidingen worden aangeboden zal bovendien nauwelijks extra interesse wekken bij leerlingen die nog kiezen voor een economische of een zorgopleiding. $\mathrm{Er}$ is juist een relatief groot aandeel leerlingen dat voor techniek kiest maar woonachtig is in een gebied waar geen technische opleiding wordt aangeboden door één van de vijf ROC's die bij het onderzoek betrokken waren.

Veel leerlingen die voor techniek kiezen lijken bereid te zijn om een grotere afstand te overbruggen van thuis naar school dan economieleerlingen. De gemiddelde reistijd wijkt echter niet veel af van die van andere leerlingen omdat ze relatief vaak gebruik maken van gemotoriseerd en openbaar vervoer, en omdat er een klein deel van de economieleerlingen juist een grote reisafstand aflegt. Leerlingen die voor techniek kiezen hechten over het algemeen ook meer waarde aan een goede bereikbaarheid van de school, en vinden het minder belangrijk dat de school dichtbij huis ligt.

45. Het is van belang hier op te merken dat we in dit rapport hoofdzakelijk kijken naar of er techniek wordt aangeboden op een locatie, en niet naar de verschillende deelsectoren (bijv. werktuigbouw, grafische techniek, etc.) binnen techniek. Als er meer deelsectoren binnen techniek dan binnen andere richtingen onderscheiden worden, en als niet al deze richtingen aangeboden worden op een technieklocatie, dan betekent dat dat techniekleerlingen in vergelijking met economieleerlingen verder moeten reizen naar een andere locatie met dezelfde deelsector. 
Er kan geconcludeerd worden dat techniekleerlingen bereid zijn om een relatief grote reisafstand en reistijd voor lief te nemen, zolang de afstand van thuis naar school niet groter is dan $30 \mathrm{~km}$. en de reistijd niet meer dan één uur bedraagt (enkele reis). Onze bevinding dat een reisafstand tot $30 \mathrm{~km}$. van thuis naar school nauwelijks de opleidingskeuze beïnvloedt wordt ondersteund door eerder onderzoek (Bloemen en Dellaert, 2000).

De hogere gemiddelde reisafstand van mannelijke leerlingen ten opzichte van vrouwelijke leerlingen in combinatie met de grotere reisafstand die mannen bereid zijn af te leggen, biedt geen verklaring voor de gemiddeld hogere reisafstand van techniekleerlingen. Uit nadere analyses - hierbij is gecorrigeerd voor verschillende andere achtergrondvariabelen zoals etniciteit, geslacht, leeftijd en niveau van de opleiding - blijkt zelfs dat de vrouwelijke technische leerlingen een grotere reisafstand (ruim $5 \mathrm{~km}$.) hebben dan de mannelijke! Verder zou het relatief grote aandeel BBL'ers bij techniek een verklaring kunnen bieden. BBL'ers hoeven immers slechts één dag per week naar school waardoor een grotere reisafstand naar school minder zwaar weegt. Bij de techniekopleidingen is dit inderdaad het geval. Bij de economieopleidingen is het verschil tussen BBL- en BOL-leerlingen echter groter. Bij de zorgopleidingen is dit juist omgekeerd: BBL-leerlingen in de zorg leggen minder kilometers af van thuis naar school (wederom gecorrigeerd voor andere factoren). Nader onderzoek is nodig om deze verschillen tussen opleidingsrichtingen te kunnen verklaren.

Concentratie van technische opleidingen in Technogebied alleen nog mogelijk in Brabantse deel

Van belang is hier verder dat het mogelijk is om vanuit elke plaats in het Technogebied binnen een straal van ongeveer $30 \mathrm{~km}$. reisafstand een opleidingslocatie van een ROC te bereiken waar een breed scala aan techniekopleidingen wordt aangeboden. Dit kan worden afgelezen uit figuur 2.3 in hoofdstuk 2 door het trekken van cirkels rondom de belangrijkste hoofd- en nevenvestigingen van de ROC's in het Technogebied.

Als de $30 \mathrm{~km}$.-grens als maximum reisafstand voor techniekleerlingen wordt gehanteerd, speelt het aanbod van technische opleidingen in Roermond, Venlo, Cuijk, Helmond en wellicht ook Eindhoven en Nijmegen een belangrijke rol voor schoolverlaters van het VMBO en HAVO die in Noord- en Midden-Limburg wonen, en willen doorstromen naar het middelbaar technisch beroepsonderwijs. Gegeven de $30 \mathrm{~km}$.-grens zijn er weinig mogelijkheden voor verdere concentratie van technische opleidingen in het Limburgse deel van het Technogebied en de aangrenzende gebieden. Binnen het Brabantse deel van het Technogebied zijn er wel voedingsgebieden van ROC's die elkaar overlappen. Hierbij kan gedacht worden aan de grote overlap in de voedingsgebieden van de technische opleidingen in Eindhoven, Helmond en Veghel (zie figuur 2.3). 
De belangrijkste determinanten bij de keuze voor een opleiding zijn de interesse in het vakgebied en de school, gevolgd door carrièrefactoren. Techniekleerlingen laten zich mogelijk bij de studiekeuze iets minder leiden door interesses in het vakgebied, maar wel door het kunnen volgen van praktijklessen. Verder hechten zij minder belang aan het kunnen doorstuderen op HBO niveau. Het lijkt erop dat veel MBO techniekleerlingen de huidige opleiding als eindstation beschouwen, zeker omdat zij sterker letten op de kansen op werk bij de studiekeuze.

Techniekleerlingen twijfelen meer bij hun studiekeuze. Zij hebben zowel vaker een andere opleiding als een andere opleidingsrichting (techniek of niet-techniek) overwogen. Toch hebben ze niet meer spijt van hun studiekeuze dan leerlingen van andere richtingen. Ze zijn eerder bereid om te kiezen voor een niet-technische opleiding dan leerlingen van andere richtingen bereid zijn om te kiezen voor techniek. In samenhang hiermee is het frappant om te zien dat in de gebieden waar technische opleidingen moeten concurreren met de economie- en zorgopleidingen om de gunst van de leerling het aandeel techniek vaak juist kleiner is dan gemiddeld. Dat betekent dat een breder opleidingenaanbod van niet-technische opleidingen op locaties waar nu techniek wordt aangeboden meer leerlingen overhaalt om voor een niettechnische opleiding te kiezen. Omgekeerd zal dit nauwelijks het geval zijn.

\section{Technisch beroep van vader van belang voor keuze voor techniek}

Vaders van techniekleerlingen zijn zelf ook vaker werkzaam in de techniek dan vaders van economieleerlingen. Dit laatste is van belang ter verklaring van de studiekeuze van jongens. Zij kiezen beduidend vaker voor een technische opleiding als hun vader werkzaam is in een technisch beroep. Techniekleerlingen geven zelf ook relatief vaak aan werkzaam te willen zijn in hetzelfde beroep als dat van hun vader. Een dalende werkgelegenheid in de technische beroepen leidt langs deze weg tot minder leerlingen die voor techniek kiezen. Ook in gebieden met minder industriële werkgelegenheid zouden dan minder leerlingen voor techniek kiezen. Dit kan een verklaring bieden voor de verschillen in deelname aan techniekonderwijs tussen de postgebieden aan het begin van dit hoofdstuk. Nader onderzoek is echter vereist om deze hypotheses te toetsen.

\section{Andere instrumenten nodig om deelname aan techniek te stimuleren}

Om de deelname aan techniek te vergroten zou men zich derhalve veeleer moeten inspannen om bij bepaalde doelgroepen meer interesse voor techniek te wekken, bijvoorbeeld bij vrouwen en allochtonen, dan om het aantal opleidingslocaties met techniek in de regio te vergroten. Mogelijk kunnen ook de vaders van leerlingen die werkzaam zijn in een technisch beroep daarbij nog een sleutelrol vervullen. Van belang is ook de kwaliteit van de instroom om voldoende leerlingen tot niveau 3 of 4 te kunnen opleiden. Bij de economische opleidingen is het aandeel in het totale aantal leerlingen weliswaar groter, maar zijn er ook relatief veel leerlingen die instromen op niveau 1. Bij de technische opleidingen is juist de instroom op niveau 2 
oververtegenwoordigd, en is de instroom op niveau 3 en 4 ondervertegenwoordigd. Ook heeft het meer zin om aandacht te besteden aan de kwaliteit van het aanbod van technische opleidingen dan aan de spreiding van het aanbod. Concentratie van dure, maar kwalitatief hoogwaardige technische opleidingen op één locatie is daarbij een reëel alternatief. Op deze wijze kan tegemoet worden gekomen aan de wensen van werkgevers om leerlingen beter op te leiden met competenties die up-to-date zijn. De leerlingen die in techniek geïnteresseerd zijn laten zich bij hun studiekeuze nauwelijks weerhouden door een iets grotere reisafstand als zij op minder dan 30 $\mathrm{km}$. van hun woonadres een technische opleiding kunnen volgen. 


\section{Conclusies}

In dit rapport staat de vraag centraal of het aanbod van technische opleidingen op de verschillende locaties van Regionale Opleidingscentra (ROC's) in het Technogebied Zuidoost-Nederland een belemmering vormt voor leerlingen om voor een technische opleiding in het middelbaar beroepsonderwijs te kiezen. Gelet op de verwachte tekorten aan technisch geschoolde arbeidskrachten (ROA, 2003) rijst de vraag of de deelname aan techniek kan worden bevorderd door op meer locaties in het Technogebied technische opleidingen aan te bieden. Hierbij is het van belang vast te stellen dat het aanbieden van technische opleidingen ten opzichte van bijvoorbeeld economische opleidingen duur is omdat er relatief veel in materieel moet worden geïnvesteerd. Dit betekent dat een andere formulering van de vraagstelling eveneens van belang is, in het bijzonder voor technische opleidingen, namelijk in welke mate het mogelijk is om technische opleidingen op een beperkt aantal locaties binnen het Technogebied te concentreren zonder dat dit leidt tot een significante daling van de deelname aan techniek.

Uit ons onderzoek blijkt dat het aanbod van technische opleidingen op de verschillende opleidingslocaties nauwelijks onderdoet voor het aanbod van economische en zorgopleidingen. Hierbij is gekeken naar de opleidinglocaties van de vijf belangrijkste ROC's in het Technogebied Zuidoost-Nederland, te weten ROC Ter Aa, Gilde Opleidingen, ROC Eindhoven, Koning Willem I College en ROC De Leijgraaf. Het blijkt mogelijk te zijn om vanuit elke plaats in het Technogebied op maximaal $30 \mathrm{~km}$. reisafstand een opleidingslocatie van een ROC te bereiken waar een breed scala aan techniekopleidingen wordt aangeboden. Uit ons en ander onderzoek (Bloemen en Dellaert, 2000) blijkt dat een reisafstand tot $30 \mathrm{~km}$. voor de meeste leerlingen weinig invloed heeft op de keuze van een opleiding. Uit ons onderzoek blijkt verder dat leerlingen die maximaal $30 \mathrm{~km}$. reizen naar school deze afstand in minder dan een uur kunnen afleggen ('van deur tot deur').

Als de $30 \mathrm{~km}$.-grens als maximum reisafstand voor leerlingen wordt gehanteerd, speelt het aanbod van technische opleidingen in Roermond, Venlo, Cuijk, Helmond en wellicht ook Eindhoven en Nijmegen een belangrijke rol voor schoolverlaters van het VMBO en HAVO die in Noord- en Midden-Limburg wonen, en willen doorstromen naar het middelbaar technisch beroepsonderwijs. Er zijn echter weinig mogelijkheden voor verdere concentratie van technische opleidingen in het Limburgse deel van het Technogebied en de aangrenzende gebieden. Binnen het Brabantse deel van het Technogebied zijn er wel voedingsgebieden van ROC's die elkaar overlappen. Hierbij kan gedacht worden aan de grote overlap in de voedingsgebieden van de technische opleidingen in Eindhoven, Helmond en Veghel.

ROC's dienen bij het vaststellen van het aanbod van opleidingen, rekening te houden met de afnemende leerlingenaantallen in de technische richtingen. Om de kosten van een technische opleiding bij afnemende leerlingenaantallen in redelijke mate te kunnen blijven dragen, is concentratie van technische opleidingen op één opleidings- 
locatie een mogelijke oplossing. Vanuit het perspectief van de RoC's levert samenbundeling en ruimtelijke concentratie van verwante technische opleidingen voordelen van schaal en synergie. De drempels voor vernieuwing van opleidingen via processen van afbouw, opstarten en herstructurering worden lager. Door continue investeringen in het opleidingenaanbod kan de kwaliteit van de technische opleidingen up-to-date blijven, en waar nodig verder worden verbeterd. Ondanks dat werkgevers baat hebben bij continue investeringen in de kwaliteit van de technische opleidingen, zijn zij samen met de gemeentes in het Technogebied beducht voor een verschraling van het lokale opleidingenaanbod en een nog sterkere afname van het aantal leerlingen dat voor techniek kiest. Zij vrezen dat dit leidt tot een vergroting van de knelpunten in de personeelsvoorziening voor technisch geschoolde arbeidskrachten in de regio. Verder wijzen zij op het risico van een afname van de lokale economische bedrijvigheid en een geringere aantrekkelijkheid van de regio als werken woongebied als er geen adequate lokale onderwijsinfrastructuur meer is.

De vrees voor een toenemende schaarste aan technisch geschoold personeel is niet ongegrond. Voor de jaren tot 2008 wordt in Nederland een tekort voorzien aan technische geschoolde arbeidskrachten op MBO-, HBO- en WO-niveau (ROA, 2003). Dit tekort ontstaat door een te geringe belangstelling van leerlingen voor techniek om de uitstroom van ouder technisch personeel op te vangen, en niet door werkgelegenheidsgroei in de technische beroepen. De werkgelegenheid in de technische beroepen daalt immers structureel, zowel in Nederland als geheel als in het Technogebied. Van belang is verder dat de regionale arbeidsmarkt in het Technogebied de afgelopen jaren krapper was dan landelijk. In het Technogebied hadden werkgevers over het algemeen meer moeite om goed gekwalificeerd personeel (technisch en niet-technisch) aan te trekken dan in de rest van het land. Opmerkelijk is verder dat in het Technogebied - in tegenstelling tot landelijk - de schaarste aan technisch opgeleide MBO'ers groter lijkt te zijn dan de schaarste aan technisch opgeleide HBO'ers.

Gedurende de laatste jaren is het aantal leerlingen dat kiest voor een technische middelbare beroepsopleiding afgenomen, ondanks dat het totaal aantal leerlingen binnen het MBO is gestegen. De populariteit van een technische studie op het MBO is dus dalende, vooral voor MBO techniek in het Technogebied, maar ook landelijk. Bovendien zien we de dalende populariteit van techniek ook terug binnen het VMBO en HBO. De sterk gedaalde belangstelling voor MBO techniek binnen het Technogebied hangt deels samen met het door de neergaande conjunctuur afgenomen aantal leerlingen in de beroepsbegeleidende leerweg (BBL) na het schooljaar 1999/2000. Meer dan de helft van het aantal techniekleerlingen volgt een BBLopleiding. Verder hangt de sterk gedaalde belangstelling voor techniek in het Technogebied samen met de daling van een belangrijke deelsector binnen techniek, namelijk elektrotechniek. Het sterk afgenomen aantal leerlingen bij elektrotechniek is deels te verklaren uit de flinke toename in de belangstelling voor ICT. Veel ICTopleidingen zijn echter meer economisch dan technisch georiënteerd.

Het aanbod van technische opleidingen in Maaseik aan het Technisch Instituut Sint Jansberg speelt geen rol bij de afnemende belangstelling voor techniek onder 
leerlingen die het VMBO in Nederland afmaken: er zijn nauwelijks leerlingen die na het behalen van het VMBO-diploma kiezen voor een technische opleiding in Vlaanderen. Er zijn weliswaar veel Nederlandse leerlingen die aan het Technische Instituut Sint Jansberg een technische opleiding volgen, maar deze leerlingen zijn al (veel) eerder in het Vlaamse onderwijs ingestroomd.

Het is wel van belang om te constateren dat de afname van het aandeel leerlingen binnen de technische richtingen parallel loopt aan het dalende werkgelegenheidsaandeel in de industrie en de technische beroepen in de regio, i.e. het Technogebied. Het aandeel leerlingen dat voor techniek kiest ligt regionaal hoger dan landelijk, evenals het aandeel van de werkgelegenheid in de technische beroepen. Echter, de daling van zowel de belangstelling voor techniek onder leerlingen als het werkgelegenheidsaandeel van de technische beroepen is regionaal sterker dan landelijk. Er is hier dus op twee fronten - onderwijs en arbeidsmarkt - sprake van convergentie tussen het Technogebied en Nederland.

Leerlingen houden bij hun studiekeuze rekening met de kans op werk, de arbeidsvoorwaarden en de carrièreperspectieven (zie ook Bloemen en Dellaert, 2000). Derhalve is het niet verwonderlijk dat de populariteit van een technische opleiding mede wordt bepaald door de omvang van de werkgelegenheid in de industrie en de technische beroepen. Daarbij komt, zoals uit voorliggend onderzoek is gebleken, dat mannelijke leerlingen die voor techniek kiezen zich veel sterker laten leiden door het beroep van hun vader dan mannelijke leerlingen die voor economie kiezen. Dit betekent dat een dalende werkgelegenheid in de technische beroepen ook de belangstelling voor techniek doet afnemen onder de jongens van de vaders die in deze beroepen werkzaam zijn. Langs de bovengenoemde twee mechanismen past het aanbod zich aan de vraag aan, en is er een lange-termijntendens tot het bereiken van een nieuw evenwicht op de arbeidsmarkt. Dat neemt overigens niet weg dat er op de kortere termijn wel degelijk sprake kan zijn van een 'mismatch' tussen vraag en aanbod op de arbeidsmarkt.

Voor de studiekeuze van leerlingen speelt de intrinsieke motivatie de belangrijkste rol (zie ook Bloemen en Dellaert, 2000). Hierin onderscheiden techniekleerlingen zich niet duidelijk van economieleerlingen. Hetzelfde geldt voor de keuze van een school. Wel is duidelijk dat techniekleerlingen vaker een andere opleiding hebben overwogen, en dat zij eerder geneigd zijn een niet-technische opleiding te kiezen dan economieleerlingen geneigd zijn om een technische opleiding te kiezen. Techniekleerlingen hechten meer dan economieleerlingen waarde aan praktijklessen, en minder aan een vooropleiding die gericht is op een goede doorstroom naar het HBO. Van belang voor de vraagstelling in dit onderzoek is met name dat techniekleerlingen aanzienlijk vaker dan economieleerlingen aangeven waarde te hechten aan een goede bereikbaarheid van de school met het openbaar vervoer. Leerlingen die voor techniek hebben gekozen wonen over het algemeen verder van hun school vandaan, en moeten derhalve een grotere afstand overbruggen van thuis naar school. De reistijd houden zij beperkt door meer dan economieleerlingen gebruik te maken van het openbaar vervoer of van eigen gemotoriseerd vervoer. Zij vinden de stad of de 
plaats waar de school gelegen is van beduidend minder belang, evenals of de school dichtbij huis ligt.

In aansluiting hierop laat ons onderzoek zien dat leerlingen die wonen in gebieden die verder weg van een ROC liggen, relatief vaak voor een technische opleiding kiezen. Leerlingen die in plaatsen rondom de ROC's wonen kiezen daarentegen relatief vaak voor een economie- of een zorgopleiding. Dit verband blijft gehandhaafd als er gecontroleerd wordt voor allerlei andere variabelen zoals geslacht, leeftijd, herkomst, niveau, ROC, etc. Veel leerlingen die voor techniek kiezen lijken dus bereid te zijn om een grotere afstand te overbruggen dan leerlingen van andere richtingen. Ons onderzoek laat tevens zien dat een verbreding van het opleidingenaanbod op een bepaalde locatie - bijvoorbeeld economie naast techniek - relatief veel leerlingen die in eerste instantie voor een technische studie kiezen zou kunnen overhalen om te kiezen voor een economische opleiding, terwijl dit andersom veel minder het geval lijkt te zijn. Dit is te verklaren doordat leerlingen die een technische opleiding volgen veel vaker aangeven een andere (niet-technische) opleiding te hebben overwogen, dan dat leerlingen die een economische opleiding volgen aangeven dat zij een andere (technische) opleiding hebben overwogen.

Het bovenstaande betekent dat een uitbreiding van het aantal locaties waar techniek wordt aangeboden in het Technogebied weinig extra leerlingen voor techniek zal winnen. Ten eerste omdat leerlingen die voor techniek kiezen een grotere bereidheid vertonen dan leerlingen van andere richtingen om een relatief grote reisafstand - tot $30 \mathrm{~km}$.- te overbruggen. De spreiding van opleidingslocaties in het Technogebied is momenteel zodanig dat elke leerling in het Technogebied binnen een straal van 30 $\mathrm{km}$. een ROC met een technische opleiding kan bereiken. Ten tweede zullen leerlingen van bijvoorbeeld economische (incl. ICT) richtingen niet zo gemakkelijk kunnen worden overgehaald om een technische opleiding te volgen.

Om de deelname aan techniek te vergroten zou men zich derhalve veeleer moeten inspannen om bij bepaalde doelgroepen meer interesse voor techniek te wekken, bijvoorbeeld bij vrouwen en allochtonen, dan om het aantal opleidingslocaties met techniek in de regio te vergroten. Mogelijk kunnen ook de vaders van leerlingen die werkzaam zijn in een technisch beroep daarbij nog een sleutelrol vervullen. Van belang is ook de kwaliteit van de instroom om voldoende leerlingen tot niveau 3 of 4 te kunnen opleiden. Ook heeft het binnen het Technogebied meer zin om aandacht te besteden aan de kwaliteit van het aanbod van technische opleidingen dan aan de uitbreiding van het aantal locaties waar techniek wordt aangeboden. Concentratie van dure, maar kwalitatief hoogwaardige technische opleidingen op één locatie is daarbij een reëel alternatief. Op deze wijze kan tegemoet worden gekomen aan de wensen van werkgevers om leerlingen beter op te leiden met competenties die up-todate zijn. 


\section{Referenties}

Asselberghs K., R. Batenburg, F. Huijgen \& M.C. de Witte (1998), De kwalitatieve structuur van de werkgelegenheid in Nederland: deel IV, OSA-voorstudie V44, Den Haag.

Bloemen, H. en B. Dellaert (2000), De studiekeuze van middelbare leerlingen, Een analyse van motieven, percepties en preferenties, OSA A 176, Tilburg.

Borghans, L. (1999), Arbeidsrelevante studie en beroepskeuzes van jongeren, OSA A 168, Tilburg.

Borghans, L. en M. de Steur (1999), Kiezen voor de zorg. Een conceptueel kader, OSA-Z 39, Tilburg.

Borghans, L., F. Cörvers, B. Golsteyn, M. Hensen (2005), De Gelderse arbeidsmarkt 20032008, ROA-R-2005/2, Maastricht.

CBS (2002), Leerlingen in perspectief. Nieuwe prognose van leerlingen- en studentenaantallen, Index, no.1, Voorburg/Heerlen.

CBS (2004), Standaard Onderwijsindeling 2003 Editie 2004/'05, Voorburg/Heerlen.

CINOP (2002), Imago-onderzoek Laboratoriumonderwijs, 's-Hertogenbosch.

Cornielje, J. (2004), Grensoverschrijdend leren in de techniek, De kwaliteit van het Nederlandse technisch beroepsonderwijs aan de hand van de stroom van Nederlandse leerlingen naar Vlaanderen, Faculteit der Cultuurwetenschappen, Universiteit Maastricht.

Eijs, P. van (2003), De arbeidsmarkt voor MBO-schoolverlaters: nu en straks (editie 2003), ROA-R-2003/7, Maastricht.

Grip, A. de, en S. Dijksman (2004), Winnaars en verliezers op de arbeidsmarkt 1995-2000: naar een kenniseconomie? Tijdschrift voor Arbeidsvraagstukken, Vol. 20, pp. 169-181.

Innovatieplatform (2003), Deltaplan bèta/techniek, Stichting Nederland Kennisland, Amsterdam.

Kuijk, J. van, en F. Wartenbergh-Cras (2004), Doorstroom in de regio, Onderzoek naar de doorstroom van vmbo (Raayland College) naar mbo, andere opleidingen en werk, Instituut voor Toegepaste Sociale Wetenschappen (ITS), Nijmegen.

OCW (1997), Ontwerp Hoger onderwijs en onderzoeksplan 1998, Zoetermeer.

OCW (2003), Kerncijfers 1998-2002 Onderwijs, Cultuur \& Wetenschappen, Zoetermeer.

ROA (2002), ROA-classificatiegids 2002, ROA-R-2002/3, Maastricht.

ROA (2003), De Arbeidsmarkt naar opleiding en beroep tot 2008, ROA-R-2003/11, Maastricht. 



\section{Bijlage 1 Ontwikkeling van het aantal leerlingen en gediplomeerden van aan techniek grenzende opleidingen}

In de analyse van technische opleidingen is de SOI-indeling van het CBS gebruikt om te bepalen wat bij de sector techniek hoort en wat niet. Het gebruik van deze indeling heeft tot gevolg dat opleidingen die door het ROA wel als technisch worden geclassificeerd (ROA, 2002) in hoofdstuk 2 en 3 niet als techniekopleiding worden beschouwd. De indeling die het ROA hanteert is tot stand gekomen door te kijken naar de beroepen waarin personen met een bepaalde opleidingsachtergrond terechtkomen. De indeling van het CBS kijkt in eerste instantie naar de plaats waar een opleiding thuishoort vanuit het perspectief van het onderwijsstelsel. In deze bijlage wordt verder ingegaan op de opleidingssectoren die zich op het grensvlak tussen techniek en andere richtingen bevinden. Ook voor deze opleidingen is de ontwikkeling van het aantal leerlingen en gediplomeerden onderzocht.

Het gaat om opleidingen uit de volgende deelsectoren. (1) Laboratoriumtechniek: Opleidingen in deze richting worden door het CBS onder 'opleidingen in de wiskunde en natuurwetenschappen' geplaatst. (2) Transport \& Logistiek: Deze opleidingen plaatst het CBS onder de noemer 'Transport-, communicatie- en verkeersonderwijs', al dan niet met een verdere differentiatie. (3) Automatisering: Deze ICT-opleidingen worden deels onder 'Economisch, administratief en commercieel onderwijs' geschaard, in tegenstelling tot de ICT-opleidingen die onder elektrotechniek vallen. (4) Enkele technische opleidingen die het CBS onder de noemer 'Agrarisch met technisch onderwijs' of 'Medisch, paramedisch onderwijs' plaatst.

Voor details over de afbakening van techniekopleidingen aan de hand van de Standaard Onderwijsindeling (SOI) van het CBS wordt verwezen naar Bijlage 2.

Het totale leerlingenaantal in Nederland voor MBO-opleidingen in de bovengenoemde deelsectoren is tussen 1997/'98 en 2003/'04 verdubbeld van 20.600 tot 40.200. In het Technogebied steeg het aantal leerlingen van 2.200 tot ruim 3.900 leerlingen. Deze grote toename mag bijna volledig aan de groei van de ICTopleidingen toegeschreven worden.

Bij de VMBO-opleidingen in de bovengenoemde deelsectoren alleen om de opleidingen transport \& logistiek, zie hieronder voor de gegevens.

Bij de HBO-opleidingen in de bovengenoemde deelsectoren nam het aantal leerlingen toe van ongeveer 14.776 in $1997 /$ '98 tot 17.432 leerlingen in $2002 /{ }^{\prime} 03{ }^{46}$ In het Technogebied worden deze aan techniek grenzende HBO-opleidingen niet aangeboden.

46. Bij HBO-opleidingen wordt het schooljaar 2002/'03 als laatste jaar gehanteerd, vanwege de nieuwe rekenmethode van het CBS vanaf 2003/'04 en de grote verschuivingen die dit tot gevolg had. Zie hoofdstuk 3. 


\section{Laboratoriumtechniek}

De MBO-opleidingen binnen laboratoriumtechniek zijn misschien wel het grootste slachtoffer van de teruglopende belangstelling voor techniek. Het aantal leerlingen is tussen 1997/'98 en 2003/'04 met meer dan 53\% gedaald tot 3.156 leerlingen. In het Technogebied liep het aantal leerlingen laboratoriumtechniek eveneens terug; het aantal leerlingen halveerde tot 473 in 2003/'04.

Deze drastische terugloop heeft al geleid tot het sluiten van de opleidingen laboratoriumtechniek in Venlo (zie hoofdstuk 5 voor de overwegingen hierbij). Bij de HBO-opleidingen is de afname kleiner: $21 \%$ minder leerlingen in 2002/'03.

\section{Transport \& logistiek}

$\mathrm{Bij}$ de MBO-opleidingen transport \& logistiek is het leerlingenaantal vrij stabiel gebleven gedurende de zeven jaren van meting. Na een aanvankelijke stijging is het aantal leerlingen nu weer ongeveer gelijk aan het schooljaar 1997/'98. Met een stijging van bijna 4\% zijn er dus in 2003/'04 ongeveer 9.100 leerlingen in deze opleidingen. In het Technogebied gaat het om een lichte stijging van 673 naar 685 leerlingen. Voor het VMBO ziet het er heel anders uit. Het aantal leerlingen is namelijk meer dan verdubbeld (naar 1.286) en het aantal gediplomeerden verviervoudigd (naar 572). Ook in het Technogebied is dit aantal gestegen. Het aantal leerlingen nam toe van 65 tot 165 . Bij de HBO-opleidingen Transport \& Logistiek is het aantal leerlingen in 2002/'03 ten opzichte van het jaar 1997/'98 gedaald met $21 \%$. In het Technogebied worden deze HBO-opleidingen, die relatief weinig op techniek georiënteerd zijn (zie vorige bladzijde), niet aangeboden. In het Technogebied worden de meeste technische transport- en logistieke opleidingen wel aangeboden, namelijk in Venlo (de laatste opleidingen vallen dus wel onder de definitie van techniek).

\section{Automatisering}

Bij MBO automatisering is het aantal leerlingen sinds 1997/'98 enorm toegenomen. Het aantal leerlingen is bijna verzesvoudigd van ongeveer 4.600 naar 27.400 leerlingen. In het Technogebied is het aantal leerlingen meer dan vervijfvoudigd van 536 naar 2.718 .

Op HBO-niveau zijn de aantallen leerlingen in 2002/'03 ook gestegen, namelijk met respectievelijk $61 \%$ ten opzichte van 1997/'98. In het Technogebied worden HBOopleidingen binnen automatisering niet aangeboden. Het gaat dan om HBOopleidingen in de automatisering die niet technisch maar economisch georiënteerd zijn.

In een onderzoek van Cinop (2002) wordt aangegeven dat een groot deel van leerlingen die voorheen voor technische MBO-opleidingen kozen, de laatste jaren voor een ICT-opleiding kiezen. De ontwikkeling van de deelname aan het MBO lijkt erop te wijzen dat een aanzienlijk deel van de leerlingen die eerder voor een technische MBO-opleiding koos nu een opleiding ICT/Automatisering volgt. Deze richting valt deels binnen Economie \& Handel. 
Overig

Naast de drie bovenstaande subsectoren zijn er ook nog enkele opleidingen uit de subsectoren MBO werktuigbouw, MBO mechanische techniek en HBO elektrotechniek, die volgens de SOI-classificatie niet bij techniek horen en dus niet inbegrepen zijn in deze analyse. Het gaat voor de soorten MBO-opleidingen om een toename van 15\% leerlingen (van 485 tot 560). In het Technogebied daalt het aantal leerlingen van 76 naar 43. Bij HBO elektrotechniek steeg het aantal leerlingen met $20 \%$ van 561 naar 674 in 2002/'03. In het Technogebied worden deze specifieke HBOopleidingen binnen elektrotechniek niet aangeboden. 



\title{
Bijlage 2 Afbakening van technische en niet- technische opleidingen
}

\author{
Volgens de SOI-classificatie 2003/'04 van het CBS worden de volgende \\ rubrieksgroepen tot de sector techniek gerekend: Opleidingen waarvan de laatste 4 \\ posities van de SOI-classificatie tussen 3500 en 3999 ligt. Feitelijk beginnen de \\ codes bij 3611 en eindigen ze bij 3888.
}

\section{5 technisch onderwijs}

36 technisch onderwijs zonder nadere differentiatie

361 bouwkunde

3611 meubelmaken en timmeren 3613 beton- en staalbouwkunde 3614 metselen en stukadoren 3615 schilderen en decoreren 3616 installatietechniek (gas, water, cv, dakbedekking) 3617 interieurverzorging 3618 bouwkunde overig en algemeen

362 weg- en waterbouwkunde, landmeetkunde

3623 weg- en waterbouwkunde 3625 landmeetkunde

363 metaalbewerking

3631 gieterijtechniek en metaalkunde 3633 constructiewerken, lassen, smeden 3635 fijnmechanische techniek 3638 metaalbewerking overig en algemeen

364 werktuigbouwkunde

3641 voertuigbouwkunde 3643 scheepsbouwkunde 3645 vliegtuigbouwkunde 3646 bedrijfswtk, machinisten ed 3647 monteurs, reparateurs ed neg 3648 werktuigbouwkunde overig en algemeen (tekenaars, constructeurs) 
365 elektrotechniek

3651 elektrische energietechniek

3652 computer en informatica

3653 elektronica algemeen/radio-tv

3654 telecommunicatie/datacommunicatie

3655 industriele procesautomatisering

366 grafische techniek

3661 papierverwerking/-veredeling

3663 drukvormvervaardigingstechniek

3665 druktechniek

3667 bind- en afwerkingstechniek

3668 grafische techniek overig en algemeen

367 procestechniek

3671 metallurgie, keramiek

3672 papier, strokarton, rubber

3673 textiel, leer

3674 petrochemie, kunststoffen

3675 chemie overig en onbenoemd

3676 voedings- en genotmiddelen meelprodukten

3677 voedings- en genotmiddelen overig en onbenoemd

3678 procestechniek overig en algemeen

368 techniek overig

3682 fysische techniek

3683 toegepaste wiskunde

3685 textiel-, leerverwerking

3688 techniek overig neg

\section{8 technisch met econ/admin en commerc onderwijs}

\section{1 bouwkunde}

3811 meubelmaken en timmeren

3814 metselen en stukadoren

3815 schilderen en decoreren

3816 installatietechniek (gas, water, cv, dakbedekking)

3817 interieurverzorging

3818 bouwkunde overig en algemeen 
382 weg- en waterbouwkunde

3823 weg- en waterbouwkunde

383 metaalbewerking

3831 gieterijtechniek en metaalkunde

3833 constructiewerken, lassen, smeden

3835 fijnmechanische techniek

3838 metaalbewerking overig en algemeen

384 werktuigbouwkunde

3841 voertuigbouwkunde

3843 scheepsbouwkunde

3847 monteurs, reparateurs ed neg

3848 werktuigbouwkunde overig en algemeen

385 elektrotechniek

3851 elektrische energietechniek

3853 elektronica algemeen/radio-tv

386 grafische techniek

3867 bind- en afwerkingstechniek

3868 grafische techniek overig en algemeen

387 procestechniek

3872 papier, strokarton, rubber

3873 textiel, leer

3874 petrochemie, kunststoffen

3876 voedings- en genotmiddelen, meelprodukten

3877 voedings- en genotmiddelen overig en onbenoemd

388 techniek overig

3885 textiel-, leerverwerking

3888 techniek overig neg 



\section{Bijlage 3 Technische MBO-opleidingen in het Technogebied Zuidoost-Nederland}

\begin{tabular}{|c|c|c|}
\hline Naam en plaats & Vestiging & Toelichting \\
\hline \multicolumn{3}{|c|}{ Gilde Opleidingen } \\
\hline Roermond & Hoofdvestiging & $\begin{array}{l}\text { Elektrotechniek, procestechniek, } \\
\text { Installatietechniek, werktuigbouw- } \\
\text { kunde, grond-, water- en } \\
\text { wegenbouw, bouwkunde, hout- en } \\
\text { meubeltechniek (alleen BBL), } \\
\text { schilderen }\end{array}$ \\
\hline Roermond & AOC & $\begin{array}{l}\text { Agrarisch Opleidingscentrum, } \\
\text { opleidingen landbouwmechanisatie } \\
\text { Gilde }\end{array}$ \\
\hline Roermond & Opleidingsbedrijf & $\begin{array}{l}\text { Regionaal Opleidingsbedrijf } \\
\text { Installatietechniek }\end{array}$ \\
\hline Roermond & Opleidingsbedrijf & Schildersvakcentrum \\
\hline Venlo & Nevenvestiging & $\begin{array}{l}\text { Elektrotechniek, Installatietechniek, } \\
\text { werktuigbouwkunde, grond-, water- } \\
\text { en wegenbouw }\end{array}$ \\
\hline Venlo & Nevenvestiging & $\begin{array}{l}\text { Bouwkunde, hout- en } \\
\text { meubeltechniek }\end{array}$ \\
\hline Venlo & Opleidingsbedrijf & $\begin{array}{l}\text { Technisch Opleidingscentrum } \\
\text { Limburg, Verspaningscentrum \& } \\
\text { Fijnplaatwerk Centrum, wordt } \\
\text { gesloten }\end{array}$ \\
\hline Venray & Opleidingsbedrijf & $\begin{array}{l}\text { Technisch Opleidingscentrum } \\
\text { Limburg, Las-, Constructie- en } \\
\text { Verspaningscentrum, wordt } \\
\text { gesloten }\end{array}$ \\
\hline Weert & Opleidingsbedrijf & $\begin{array}{l}\text { SPB Bouwopleidingen, Regionaal } \\
\text { opleidingsbedrijf Bouwsector }\end{array}$ \\
\hline Weert & Opleidingsbedrijf & $\begin{array}{l}\text { Technisch Opleidingscentrum, Las- } \\
\text { en Constructie Centrum, wordt } \\
\text { gesloten }\end{array}$ \\
\hline Horst & Opleidingsbedrijf & $\begin{array}{l}\text { Bouw OpleidingsCentrum, } \\
\text { Voormalig Innovatie en } \\
\text { Praktijkcentrum, facilitair centrum } \\
\text { voor beroepsopleidingen voor de } \\
\text { bouw en aanverwante sectoren en } \\
\text { branches }\end{array}$ \\
\hline
\end{tabular}


ROC Eindhoven

Eindhoven

Eindhoven

Eindhoven

Nuenen

Veldhoven

Eindhoven

De Eindhovense School

Eindhoven

Helmond

Helmond

Mierlo

Nuenen
Hoofdvestiging Autobranche en mobiliteit, bouwkunde en bouwtechniek (BOL 4), elektrotechniek, Hout Meubel \& Interieurafwerking, Installatietechniek, Werktuigbouwkunde \& Metaal

Nevenvestiging Afbouw- \& Afwerkingstechnieken, Bouwkunde en bouwtechniek (BOL $1 / 2$ en $B B L$ )

Nevenvestiging Laboratorium-, Milieu- \& Procestechniek

Nevenvestiging Afbouw- \& Afwerkingstechnieken, Schildersvakcentrum, samenwerkingsverband met Savantis, SPOS en ROC Ter AA Opleidingsbedrijf ROI Brabant, Regionaal Opleidingsbedrijf Installatietechniek Opleidingsbedrijf RIVB, Reg. Instituut voor Vak- en Beroepsonderwijs

Vakschool School voor grafische techniek en multimedia

Hoofdvestiging Bouwkunde en bouwtechniek BOL 4, Elektro/ICT, Werktuigbouw, Installatietechniek, Procestechniek, Textieltechniek

Opleidingsbedrijf ROI Brabant en ROI Zuidoost; Regionaal Opleidingsbedrijf Installatietechniek

Nevenvestiging Bouwkunde en bouwtechniek BOL 2 en BBL

Nevenvestiging Nevenvestiging van School voor Afbouw- \& Afwerkingstechnieken, Schildersvakcentrum, samenwerkingsverband met Savantis, SPOS en ROC Eindhoven 


\section{ROC de Leijgraaf}

Veghel

Oss

Oss

Oss

Uden

Cuijk

Cuijk

Veghel

Cuijk

'ROC' Cuijk

Cuijk

Koning Willem 1 College

's-Hertogensbosch

Rosmalen (gemeente

's-Hertogensbosch)
Hoofdvestiging Bouwkunde, Elektrotechniek, Installatietechniek, Werktuigbouwkunde

Nevenvestiging Bouwkunde, Elektrotechniek, Werktuigbouwkunde

Nevenvestiging Bouwkunde BBL

Nevenvestiging Laboratorium \& procestechniek

Nevenvestiging Bouwkunde, Hout \& meubel, Motorvoertuigentechniek

Nevenvestiging Bouwkunde BBL

Nevenvestiging Bouwkunde, Elektrotechniek, Werktuigbouwkunde

Opleidingsbedrijf ROI Brabant, Regionaal Opleidingsbedrijf Installatietechniek

Opleidingsbedrijf ROI Brabant, Regionaal

Opleidingsbedrijf Installatietechniek

Hoofdvestiging Metaal en Elektrotechniek, Installatietechniek, Stichting Regionaal Opleidingscentrum Cuijk, geen ROC in de zin van de regelgeving van het Ministerie van OCW, in samenwerking met ROC de Leijgraaf

Hoofdvestiging Metaal en Elektrotechniek, Werktuigbouwkunde, Installatietechniek, Bouwkunde, Procestechniek, Motorvoertuigentechniek, alle opleidingen op Campus Techniek

Opleidingsbedrijf ROI Brabant, Regionaal Opleidingsbedrijf Installatietechniek

Nevenvestiging Schildersopleidingen BBL 
De Rooi Pannen

Eindhoven

St. Lucas

Boxtel

Vakschool

\section{Helicon opleidingen}

Boxtel
Nevenvestiging Brood en banket BOL 1 en 2

Communicatie \& reclame, Interieur \& presentatie en Vastgoed \& onderhoud, BOL-opleiding Schilders/afwerkingstechnieken

Nevenvestiging Monteur(-chauffeur),

gemechaniseerd loonwerk

Opmerkingen:

- Met name voor de hoofdvestigingen van de ROC's in Roermond, Eindhoven, Helmond, Veghel en 's-Hertogensbosch is het aanbod van technische opleidingen heel breed, en zijn niet alle opleidingen in detail weergegeven. Zo valt bijv. onder procestechniek ook de richting Brood en banket, welke voor De Rooi Pannen (nevenvestiging in Eindhoven, hoofdvestiging buiten Technogebied in Tilburg) apart is weergegeven.

- De hierboven weergegeven opsomming van opleidingen is gebeurd aan de hand van de afdelingen/units die door de ROC's worden onderscheiden. De organisatorische indeling van opleidingen in afdelingen/units kan per ROC nogal verschillen. Zie de websites van o.a. de ROC's, de BVE Raad en de verschillende opleidingsbedrijven voor meer informatie over het onderwijs-aanbod.

- Het aanbod van de verschillende onderwijsinstellingen en de samen-werkingsverbanden in opleidingsbedrijven en vakcentra is aan veranderingen onderhevig. 


\title{
Bijlage 4 Hoofdvestigingen van VMBO-scholen in het Technogebied Zuidoost-Nederland
}

\author{
Plaats \\ Techniek Naam
}

$\begin{array}{ll}\text { Limburg } & \text { ja } \\ \text { Venray } & \text { ja } \\ \text { Venlo } & \text { ja } \\ \text { Venlo } & \text { ja } \\ \text { Venlo } & \text { ja } \\ \text { Horst } & \text { ja } \\ \text { Panningen } & \text { nee } \\ \text { Weert } & \text { nee } \\ \text { Weert } & \text { ja } \\ \text { Weert } & \text { nee } \\ \text { Roermond } & \text { nee } \\ \text { Roermond } & \text { ja } \\ \text { Roermond } & \text { ja } \\ \text { Roermond } & \text { nee } \\ \text { Horn } & \text { ja } \\ \text { Echt } & \text { ja } \\ \text { Gennep } & \end{array}$

\author{
Raayland college \\ Den Hulster \\ Valuascollege \\ Blariacumcollege \\ Dendron College \\ Bouwens van der Boije college \\ Bisschoppelijk college weert- \\ cranendonck \\ SG Philips van Horne (voor techniek naar Het \\ Kwadrant) \\ Het Kwadrant \\ AOC Limburg \\ Stedelijk Lyceum \\ Bisschoppelijk college Broekhin \\ Bisschoppelijk college \\ Schöndeln \\ SG St. Ursula \\ Bisschoppelijk college Echt \\ Hezeland college
}

\section{Noord-Brabant}

$\begin{array}{lcl}\text { Asten } & \text { ja } & \text { Varendonckcollege } \\ \text { Veldhoven } & \text { ja } & \text { Sondervick college } \\ \text { Uden } & \text { ja } & \text { Udens College } \\ \text { St. Michielsgestel } & \text { ja } & \text { Sgm V Vbo De Schalm } \\ \text { Bladel } & \text { ja } & \text { RK SGM Pius X } \\ \text { Vught } & \text { ja } & \text { Maurick College } \\ \text { Boxtel } & \text { ja } & \text { VMBO College Boxtel } \\ \text { St. Anthonis } & \text { ja } & \text { Rk Sgm Stevensbeek } \\ \text { Schijndel } & \text { ja } & \text { Elde College Schyndel } \\ \text { Cuijk } & \text { ja } & \text { Merlet Coll Land } \\ \text { Deurne } & \text { ja } & \text { Hub Van Doornecollege } \\ \text { Eindhoven } & \text { ja } & \text { Opb Sted Coll Eindhoven } \\ \text { 'S-Hertogensbosch } & \text { ja } & \text { Koning Willem 1 College } \\ \text { Eindhoven } & \text { ja } & \text { Het Pleincollege } \\ \text { Oss } & \text { ja } & \text { Hooghuis Lyceum } \\ \text { Valkenswaard } & \text { ja } & \text { SGM Were Di } \\ \text { Gemert-Bakel } & \text { ja } & \text { Commanderij College }\end{array}$




$\begin{array}{lll}\text { Helmond } & \text { ja } & \text { Vakcollege Dr. Knippenberg } \\ \begin{array}{l}\text { Geertruidenberg } \\ \text { (Raamsdonksveer) }\end{array} & \text { ja } & \text { Dongemond College }\end{array}$

Opm.: VMBO-scholen zonder techniek hebben alleen een theoretische leerweg. Hierbinnen is vaak wel een sector techniek opgenomen, maar het gaat dan niet om een beroepsgericht programma. 


\section{Bijlage 5 HBO-scholen in het Technogebied Zuidoost- Nederland en Zuid-Limburg}

Plaats

Limburg

Maastricht

Heerlen

Sittard

Roermond

Venlo

\section{Noord-Brabant}

Eindhoven ja

's-Hertogenbosch

Veghel

‘s-Hertogenbosch

‘s-Hertogenbosch

Helmond
Techniek (of Informatica)

Naam

alleen informatie, dienstverlening en management

ja

alleen bedrijfskundige informatica

nee

ja (technische hogeschool, bedrijfskunde en logistiek)

Hogeschool

Zuyd

Hogeschool

Zuyd

Hogeschool

Zuyd

Fontys

Fontys

Fontys

Fontys

Fontys

Avans

HAS

alleen voedingsmiddelen- en milieutechnologie

nee

De Kempel 



\section{Bijlage 6 Afbakening van technische, aan techniek grenzende en overige beroepsgroepen}

Technische beroepen (uit Technische en industrieberoepen, ROA, 2002)

Productiemedewerkers

Conciërges

Hoofden technische dienst

Werktuigbouwkundigen

Bouwvakkers

Aannemers en installateurs

Architecten en bouwkundig projectleiders

Weg- en waterbouwkundigen

Weg- en waterbouwkundige arbeiders

Weg- en waterbouwkundige vakkrachten

Weg- en waterbouwkundig ontwerpers en projectleiders

Metaalarbeiders

Bankwerkers en lassers

Bedrijfshoofden metaalbewerking

Assembleurs

Monteurs

Werktuigbouwkundig ontwerpers en hoofden technische dienst

Elektronicamonteurs

Monteurs en controleurs elektrotechnische producten

Elektromonteurs

Elektrotechnisch ontwerpers en bedrijfshoofden

Elektrotechnici

Grafisch productiepersoneel

Grafische vakkrachten

Mechanisch operators

Procesoperators

Procestechnologen

Materiaalkundigen

Confectie-arbeiders

Schoen- en kleermakers

Technisch systeemanalisten (uit Informaticaberoepen)

Bakkers en slagers (uit Verzorgende en dienstverlenende beroepen)

Brandweerlieden (uit Openbare orde- en veiligheidsberoepen)

Wiskundige en natuurwetenschappelijke beroepen (uit Technische en industrieberoepen, ROA, 2002)

Laboratorium-assistenten

Laboranten

Technisch analisten

Natuurwetenschappers 
Niet-technische ICT-beroepen (uit Informaticaberoepen, ROA, 2002)

Programmeurs

Systeemanalisten

Informatici

\section{Overige beroepen}

\section{Pedagogische beroepen}

Leraar basisonderwijs

Docenten exacte, medische en verzorgende vakken (2e graads)

Docenten exacte, medische en verzorgende vakken (1e graads en WO)

Docenten landbouw en techniek (2e graads)

Docenten landbouw en techniek (1e graads en WO)

Docenten economisch-administratieve vakken (2e graads)

Docenten economisch-administratieve vakken (1e graads en WO)

Docenten talen en expressie

Docenten letteren (1e graads en WO)

Docenten sociale vakken (2e graads)

Docenten sociale vakken (1e graads en WO)

Docenten 2 e graads zonder specialisatie

Docenten 1e graads zonder specialisatie

Onderwijskundig medewerkers

Onderwijskundigen en pedagogen

Rij-instructeurs

Zweminstructeurs

Sportinstructeurs

Culturele beroepen

Tolken, vertalers en schrijvers

Bibliotheekassistenten

Bibliothecarissen

Grafisch ontwerpers

Kunstenaars

Geestelijk verzorgers

Geestelijken

Journalisten

Taalkundigen

Agrarische beroepen

Agrarische hulparbeiders

Agrarische arbeiders

Agrarische vakkrachten

Milieuhygiënisten en agrarisch vertegenwoordigers

Landbouwkundigen

Landbouwmachinebestuurders en vissers

Agrarische bedrijfshoofden 
Transportberoepen

Laders en lossers

Chauffeurs

Schippers en conducteurs

Vliegers, scheepskapiteins en leidinggevenden transport

Stewards

Medische en paramedische beroepen

Verpleeghulpen en leerling-verpleegkundigen

Verplegenden en doktersassistenten

Therapeuten en verpleegkundigen

Artsen

Apothekersassistenten en medisch laboranten

Medisch analisten

Apothekers

Afdelingshoofden zorginstelling

Economisch-administratieve beroepen

Kantoorhulpen, inpakkers en colporteurs

Ondersteunende administratieve hulpkrachten

Bedrijfshoofden

Economen

Productieplanners

Organisatie-adviseurs

Organisatiedeskundigen

Receptionisten en administratieve employés

Boekhouders en secretaresses

Assistent accountants

Accountants

Verzekeringsagenten

Commercieel employés

Commercieel medewerkers

Technisch-commercieel employés

Technisch-bedrijfskundig medewerkers

Juridisch en fiscaal medewerkers

Juridisch, bestuurlijk medewerkers

Juristen

Administratieve transportemployés

Leidinggevenden

Managers

Medisch secretaresses

Sociaal-culturele beroepen

Activiteitenbegeleiders en medewerkers arbeidsbemiddeling Medewerkers sociaal-cultureel werk en personeel en arbeid Hoofden sociaal-cultureel werk en personeel en arbeid Sociaal-wetenschappelijk medewerkers 
Sociaal-wetenschappelijk onderzoekers

Verzorgende en dienstverlenende beroepen

Vakkenvullers

Interieurverzorgers

Verkopers

Winkeliers

Hulpkrachten horeca en verzorging

Ziekenverzorgenden

Verzorgend personeel

Café- en snackbarhouders

Bedrijfshoofden horeca

Openbaren orde- en veiligheidsberoepen

Aspirant politieagenten, soldaten en beveiligingshulpkrachten

Politieagenten, onderofficieren en beveiligingsemployés

Politie-inspecteurs en officieren 


\title{
Bijlage 7 Gegevensverzameling op basis van leerlingenadministraties en leerlingenenquête
}

\author{
Koppeling leeringenadministraties van vijf ROC's, selecties en verrijking \\ De gebruikte dataset van leerlingengegevens is tot stand gekomen door de \\ verschillende door de ROC's aangeleverde bestanden te koppelen. De selecties uit \\ de leerlingenadministraties is aan de hand van een gespecificeerde aanvraag van \\ het ROA uitgevoerd door de verschillende medewerkers van de ROC's. Het is echter \\ niet uit te sluiten dat verschillen in de registratiesystemen en in de administratieve \\ organisatie invloed hebben op de uitkomsten. Het betreft de nieuwe instroom die \\ geregistreerd was in het voorjaar van 2005 (schooljaar 2004/2005), excl. Contract- \\ onderwijs en volwasseneneducatie. De onderwijsnummers die meerdere keren \\ voorkwamen (door mutaties) bij een ROC werden verwijderd.
}

Aan de hand van de beschikare CREBO-codes zijn de ontbrekende SOI-codes aan de cases toegevoegd. Aangezien de SOI-codes noodzakelijk zijn bij de vaststelling of een leerling techniek studeert zijn de resterende cases zonder SOI-code uit het databestand verwijderd. Voor de afbakening van techniekopleidingen is dezelfde definitie (op basis van CREBO-nummer en SOI-code) gehanteerd als in de voorgaande hoofdstukken (zie ook Bijlage 1 en 2). De resterende leerlingen zijn ingedeeld bij de economie- en zorgopleidingen, waarbij is gekeken naar de aanduiding van de afdelingen van de ROC's. Het totale resterende bestand heeft betrekking op 15.761 leerlingen die in het voorjaar van 2005 stonden ingeschreven bij één van de vijf genoemde ROC's.

Tot slot is van alle in Nederland wonende leerlingen is met behulp van de ANWBrouteplanner de kortste afstand bepaald tussen de postcodes van het woonadres en de opleidingslocatie. De postcodes van het woonadres van leerlingen zijn tevens gebruikt om het aantal leerlingen weer te geven per 2-cijferig postcodegebied in en rondom het Technogebied.

Leerlingenenquête en weging van steekproef

De leerlingenenquête is in mei 2005 uitgevoerd met behulp van de ROC Spiegel onder eerstejaars leerlingen van Gilde Opleidingen, ROC Eindhoven, ROC De Leijgraaf en Koning Willem I College. Er zijn alleen leerlingen van niveau 2 en 4 in de richtingen techniek en economie benaderd. Het aantal respondenten in de leerlingenenquête bedroeg 282. Door onvolledige of onjuiste respons zijn 55 respondenten verwijderd uit het databestand. Dit resulteerde in 227 respondenten. Deze steekproef bleek niet representatief te zijn voor de totale populatie van eerstejaarsleerlingen van niveau 2 en 4 die techniek of economie volgen aan één van de vier bovengenoemde ROC's. Zo correspondeert de verdeling in de steekproef niet met de populatie wat betreft de vertegenwoordiging van de vier ROC's, het 
aandeel vrouwen, en het aandeel BBL'ers. De scheve verdelingen in deze steekproef zijn slechts deels te corrigeren door dit bestand te wegen.

Vanwege de sterke ondervertegenwoordiging van de vrouwen en de BBL'ers hebben we ervoor gekozen deze groepen uit de steekproef te verwijderen. Ook de leerlingen die niet in de leerlingenadministratie voorkwamen doordat zij het onderwijsnummer niet goed hadden ingevuld, of omdat zij niet nieuw in een opleiding waren ingestroomd, zijn verwijderd uit het bestand. Na de genoemde selecties resteert een bestand van 97 leerlingen met als achtergrondkenmerken: man, opleiding techniek of economie, BOL, niveau 2 of 4 , geen leerling aan ROC Ter Aa. Dit bestand is gebruikt om te wegen naar de populatie in de leerlingenadministratie met dezelfde kenmerken. Op het totale bestand van 15.761 eerstejaars leerlingen van de vijf ROC's wordt dus een aantal selecties toegepast. Na het toepassen van de selecties op de populatie resteert er een bestand van 3.886 eerstejaars leerlingen (man, opleiding techniek of economie, BOL, niveau 2 of 4 , geen leerling aan ROC Ter Aa). Dit betekent dat de steekproef 2,6\% van de geselecteerde populatie uitmaakt (ter vergelijking: de Enquête Beroepsbevolking van het CBS is een steekproef van minder dan $1 \%$ van de totale populatie).

Als weegfactor is de verdeling van het aantal leerlingen over de vier ROC's gebruikt. Deze weegfactor is gekozen omdat de kenmerken van de leerlingen van ROC's nogal kunnen verschillen (zie tabel 6.3), terwijl de verdeling tussen de geselecteerde steekproef en populatie erg afwijkt wat betreft het aantal leerlingen van de vier ROC's. Na weging kan het bestand als representatief worden beschouwd voor de mannelijke leerlingen die de beroepsopleidende leerweg (BOL) volgen op niveau 2 of 4 aan één van de vier bovengenoemde ROC's (niet ROC Ter Aa) in de richting techniek of economie. ${ }^{47}$ Door de weging naar ROC wordt ook de verdeling van niveau 2 of 4 binnen de richting techniek in de goede richting bijgesteld. De aanvankelijke sterke oververtegenwoordiging van niveau 4 in de steekproef wordt aanzienlijk gereduceerd. $\mathrm{Er}$ is echter nog steeds sprake van een oververtegenwoordiging van niveau 4 bij techniek (in de geselecteerde populatie ongeveer $70 \%$, in de gewogen steekproef ongeveer 80\%). Hieraan zal waar nodig in paragraaf 6.3 worden gerefereerd.

Verder is het aantal techniekleerlingen en economieleerlingen ongelijk verdeeld in de gewogen steekproef (49\% techniek en 51\% economie, tegenover respectievelijk ongeveer 40 en $60 \%$ in het geselecteerde populatiebestand). Dit is echter nauwelijks

47. De steekproef is niet representatief voor de verschillende deelsectoren binnen de richtingen techniek en economie. Uit voorlopige analyses zijn geen grote verschillen tussen de verschillende deelsectoren naar voren gekomen. Het onderzoek naar de verschillen in achtergrondkenmerken en preferenties tussen leerlingen van de verschillende deelsectoren viel buiten de vraagstelling van het onderzoek. De techniekleerlingen volgen vooral werktuigbouwkunde, maar ook bijv. elektrotechniek en metaal. De economieleerlingen volgen voor het merendeel een economisch georiënteerde ICTopleiding (72\%). Bij de enquêtering is er bewust gekozen voor een relatief groot aandeel ICT-leerlingen binnen economie, omdat verwacht mag worden dat deze leerlingen nog het meest geneigd zijn om techniek (i.e. technische ICT-opleiding) in plaats van economie te kiezen. 
van belang bij de bespreking in paragraaf 6.3. De resultaten van het onderzoek worden immers telkens apart voor techniek en economie weergegeven. 



\section{Bijlage 8 Aandeel leerlingen techniek per opleidingslocatie voor vijf ROC's in Technogebied Zuidoost-Nederland}

\begin{tabular}{|c|c|c|c|c|}
\hline ROC/Straat & Postcode & Plaats & $\begin{array}{r}\text { Eerstejaars } \\
\text { leerlingen } \\
\text { totaal aantal }\end{array}$ & Techniek \\
\hline \multicolumn{5}{|l|}{ ROC Ter AA } \\
\hline Keizerin Marialaan 2 & 5702 NR & Helmond & 641 & $41 \%$ \\
\hline Nieuwveld 59 & $5702 \mathrm{HW}$ & Helmond & 357 & $0 \%$ \\
\hline Totaal & & & 998 & $26 \%$ \\
\hline \multicolumn{5}{|l|}{ Gilde Opleidingen } \\
\hline Bredeweg 235 & 6042 GE & Roermond & 518 & $0 \%$ \\
\hline K.Hillenraedtstr.1 & $6043 \mathrm{HA}$ & Roermond & 684 & $97 \%$ \\
\hline Kerkeveldlaan 1 & $6042 \mathrm{JW}$ & Roermond & 527 & $10 \%$ \\
\hline Marathonlaan 4 & $6042 \mathrm{JN}$ & Roermond & 97 & $0 \%$ \\
\hline Parklaan 4 & $6131 \mathrm{KG}$ & Sittard & 122 & $0 \%$ \\
\hline 3 Decembersingel 36 & 5922 BD & Venlo & 19 & $0 \%$ \\
\hline Groenveldsingel 40 & 5913 SB & Venlo & 1161 & $23 \%$ \\
\hline Hulsterweg 2-6 & $5912 \mathrm{PL}$ & Venlo & 105 & $91 \%$ \\
\hline Laaghuissingel 4 & 5913 ES & Venlo & 471 & $0 \%$ \\
\hline Waterhoenstraat 38 & $5912 X V$ & Venlo & 16 & $100 \%$ \\
\hline Westsingel 1 & $5801 \mathrm{TT}$ & Venray & 508 & $0 \%$ \\
\hline Drakesteijn 5 & 6006 AG & Weert & 441 & $0 \%$ \\
\hline Totaal & & & 4669 & $24 \%$ \\
\hline \multicolumn{5}{|l|}{ ROC Eindhoven } \\
\hline Frederiklaan 60a & $5616 \mathrm{NJ}$ & Eindhoven & 802 & $82 \%$ \\
\hline Frederiklaan 60b & $5616 \mathrm{NJ}$ & Eindhoven & 104 & $100 \%$ \\
\hline Karel Martelweg 2 & $5616 \mathrm{JJ}$ & Eindhoven & 677 & $0 \%$ \\
\hline Rachelsmolen 1 & $5612 \mathrm{MA}$ & Eindhoven & 52 & $50 \%$ \\
\hline Ruysdaelbaan 7 & $5642 \mathrm{JJ}$ & Eindhoven & 68 & $100 \%$ \\
\hline Sibeliuslaan $2 a$ & $5654 \mathrm{CZ}$ & Eindhoven & 515 & $0 \%$ \\
\hline Sterrenlaan 6 & $5631 \mathrm{KA}$ & Eindhoven & 433 & $18 \%$ \\
\hline Sterrenlaan 8 & $5631 \mathrm{KA}$ & Eindhoven & 485 & $0 \%$ \\
\hline Sterrenlaan 10 & $5631 \mathrm{KA}$ & Eindhoven & 302 & $9 \%$ \\
\hline Totaal & & & 3438 & $28 \%$ \\
\hline \multicolumn{5}{|l|}{ Koning Willem I College } \\
\hline Onderwijsboulevard 1 & $5223 \mathrm{DE}$ & Den Bosch & 113 & $0 \%$ \\
\hline Onderwijsboulevard 3 & $5223 \mathrm{DE}$ & Den Bosch & 865 & $72 \%$ \\
\hline Vlijmenseweg 2 & $5223 \mathrm{GW}$ & Den Bosch & 1274 & $13 \%$ \\
\hline Glorieuxlaan 6 & 5261 SJ & Vught & 181 & $0 \%$ \\
\hline
\end{tabular}


ROC De Leijgraaf

De Hork 25

5431 NS Cuijk

$5431 \mathrm{NL}$ Cuijk

5431 GC Cuijk

Jan van Cuijkstraat 52

Jan van Cuijkstraat 64

Euterpelaan 100

Schelversakker 1

Sweelinckstraat 7

Udenseweg 2

Muntelaar 10

Totaal
5431 GC Cuijk

$5344 \mathrm{CS}$ Oss

5341 AJ Oss

$5344 \mathrm{AE}$ Oss

5405 PA Uden

5467 HA Veghel
$21 \quad 100 \%$

$164 \quad 100 \%$

$246 \quad 0 \%$

$33 \quad 0 \%$

$731 \quad 50 \%$

$287 \quad 0 \%$

$247 \quad 39 \%$

$64 \quad 84 \%$

$2428 \quad 20 \%$

$4221 \quad 28 \%$

Bron: ROA / ROC Ter AA / Gilde Opleidingen / ROC Eindhoven / Koning Willem I College / ROC De Leijgraaf 


\section{Bijlage 9 Afstand tussen woonadres en opleidingslocatie van eerstejaars leerlingen van vijf ROC's in het Technogebied Zuidoost- Nederland}

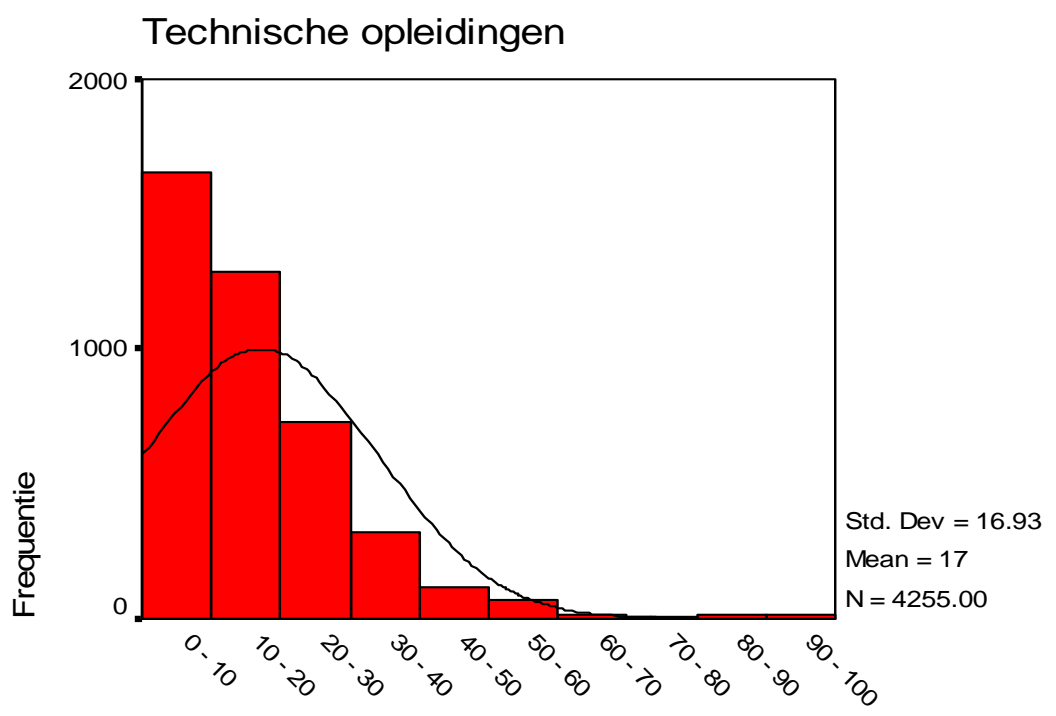

Afstand in $\mathrm{km}$.

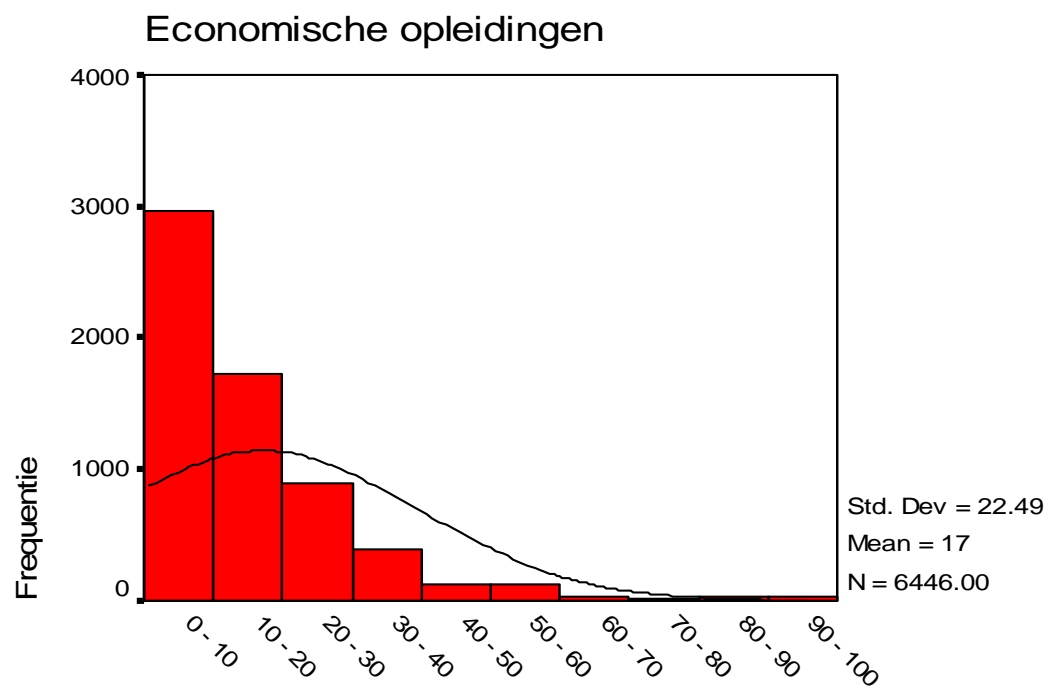

Afstand in $\mathrm{km}$. 


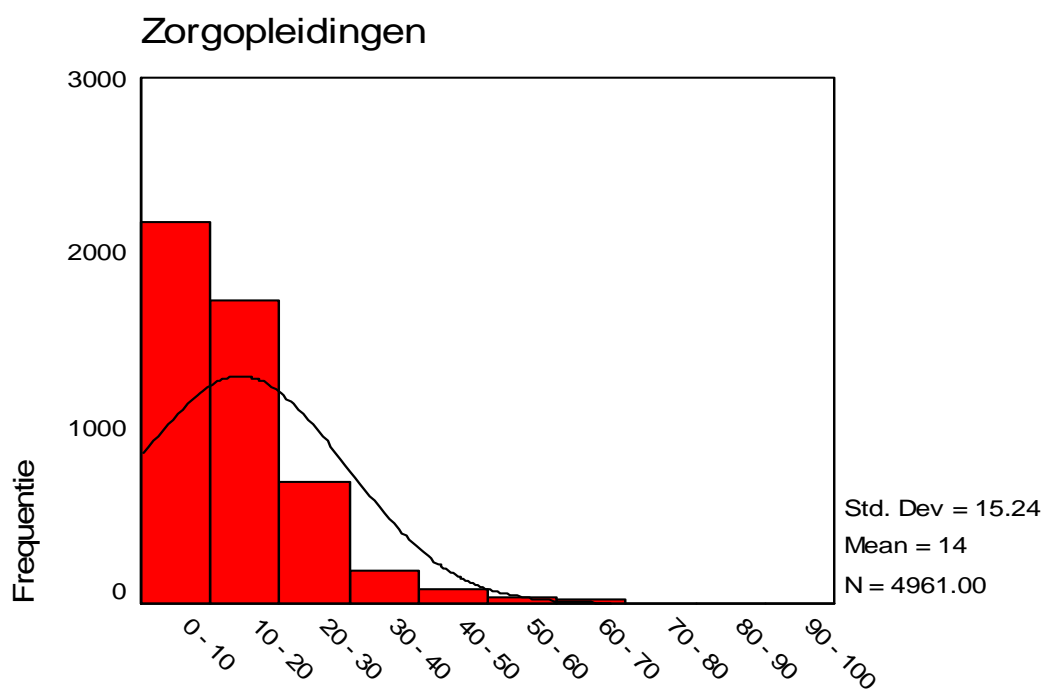

Afstand in $\mathrm{km}$.

Alle opleidingen

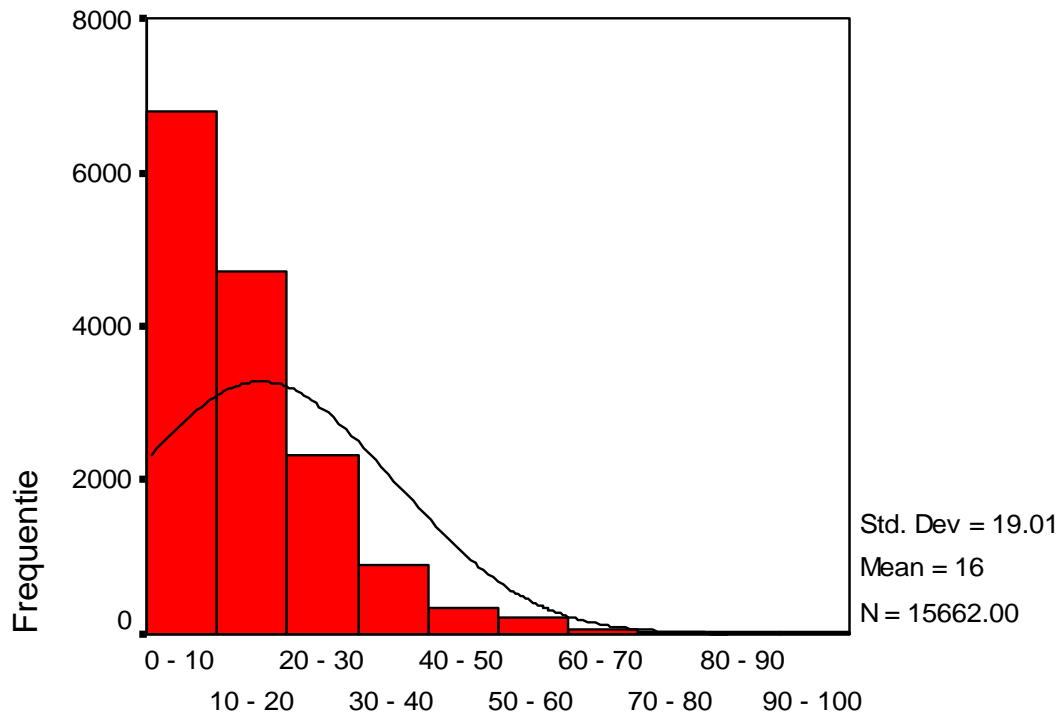

Afstand in $\mathrm{km}$.

Bron: ROA / ROC Ter AA / Gilde Opleidingen / ROC Eindhoven / Koning Willem I College / ROC De Leijgraaf 